Universidade Estadual Paulista "Júlio de Mesquita Filho" - UNESP Faculdade de Ciências e Tecnologia Programa de Pós-Graduação em Geografia

\title{
INDICADORES DE DESENVOLVIMENTO HUMANO NO CAMPO E NA CIDADE - RIBEIRÃO PRETO, SP.
}

\author{
Natália Freire Bellentani
}

Presidente Prudente - SP

Outono 2010 
Universidade Estadual Paulista “Júlio de Mesquita Filho" - UNESP Faculdade de Ciências e Tecnologia Programa de Pós-Graduação em Geografia

\title{
INDICADORES DE DESENVOLVIMENTO HUMANO NO CAMPO E NA CIDADE - RIBEIRÃO PRETO, SP.
}

\author{
Natália Freire Bellentani
}

Orientador: Prof. Dr. José Gilberto de Souza

Dissertação de Mestrado apresentada ao Programa de Pós-Graduação em Geografia - Linha de Pesquisa: Desenvolvimento Regional, para obtenção do Título de Mestre em Geografia.

\section{Presidente Prudente - SP}

Outono 2010 


\section{Bellentani, Natália Freire}

B383i Indicadores de desenvolvimento humano no campo e na cidade Ribeirão Preto, SP. / Natália Freire Bellentani. - Presidente Prudente: [s.n], 2010 197 f. : il.

Dissertação (mestrado) - Universidade Estadual Paulista, Faculdade de Ciências e Tecnologia Orientador: José Gilberto de Souza Banca: Rosângela Aparecida de Medeiros Hespanhol, José Marcelino de Rezende Pinto. Inclui bibliografia

1. Ribeirão Preto-SP. 2. Índice de Desenvolvimento Humano. 3. Assentamentos rurais 4. Periferia urbana. I. Autor. II. Universidade Estadual Paulista. Faculdade de Ciências e Tecnologia. III. Título.

CDD(18.ed.) 910

Ficha catalográfica elaborada pela Seção Técnica de Aquisição e Tratamento da Informação - Serviço Técnico de Biblioteca e Documentação - UNESP, Câmpus de Presidente Prudente. 


\section{UNIVERSIDADE ESTADUAL PAULISTA "JÚLIO DE MESQUITA FILHO" \\ Campus de Presidente Prudente}

\section{BANCA EXAMINADORA}
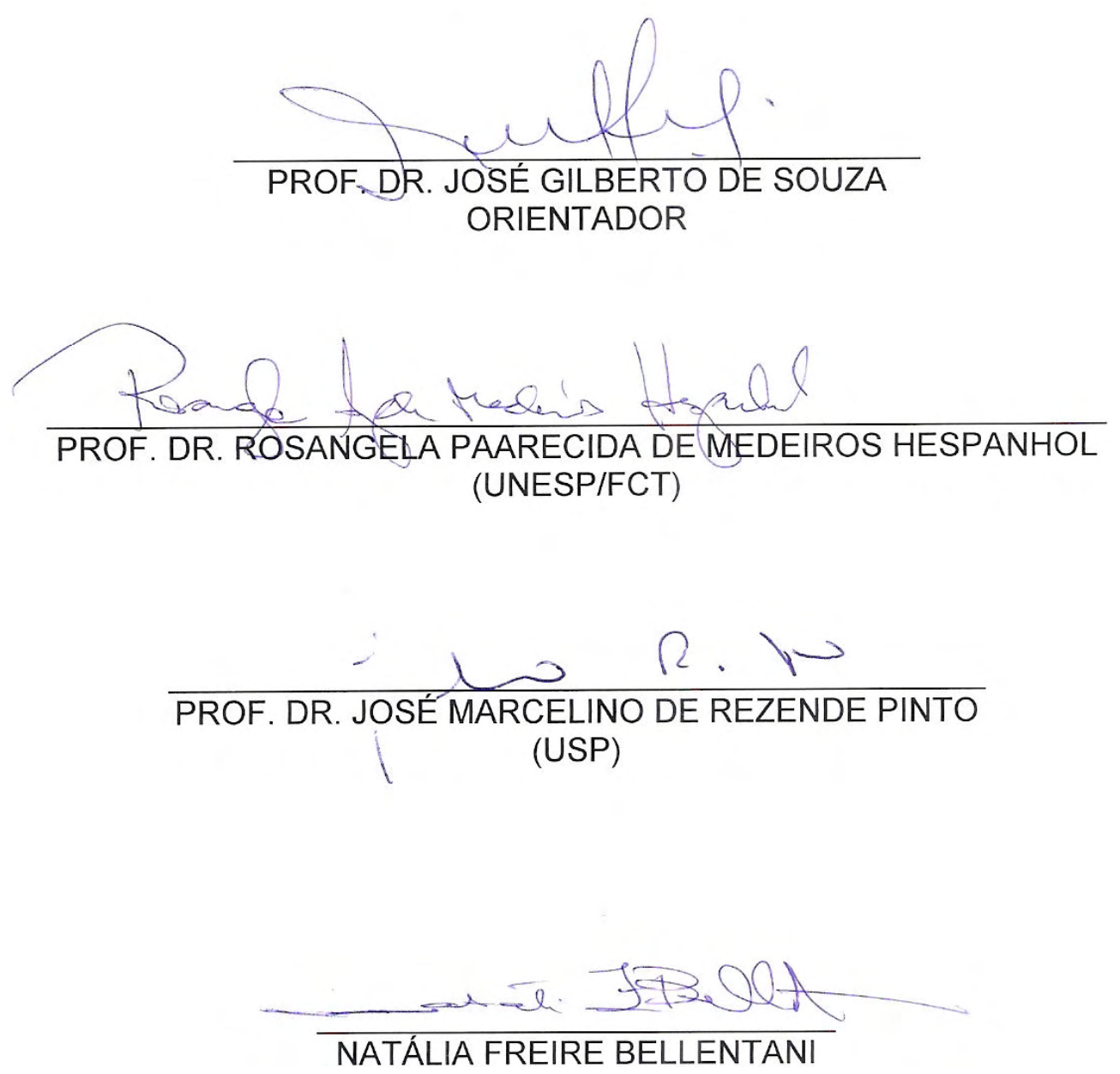

Presidente Prudente (SP), 12 de abril de 2010. 


\section{Dedicatória}

Dedico este trabaltho à minha familia

Vô Rubão e Vó Dirce,

meus pais Jussara e Bento

e meus irmãos Pricila e Fabricio. 


\section{Agradecimentos}

Ao nosso Pai Céu e nossa Mãe Terra!

Ao professor, orientador e amigo José Gillerto de Souza.

Ao amigo Sérgião Natureza.

Ao companheiro de caminhada pela Estrada Sagrada, Vinícius Soares Antunes e toda sua familia.

Ao Programa de Pós-Graduação em Geografia UNESP - Presidente Prudente/SP.

Ao Conseltho Nacional de Desenvolvimento Cientifico e Teenológico (CNPQ).

Ao Instituto Brasileiro de Geografia e Estatistica (IRGE - Ribeirão Preto/SP).

Aos assentados do Mário Lago e Sepé Tiarajú.

Aos moradores dos bairros Jardim Salgado filtho 1 e Jardim Aeroporto - Ribeirão Preto/SP.

Aos professores Rosângela Aparecida de Medeiros Hespanhol, Maria Aparecida de Moraes Silva

e José Marcelino de Rezende Pinto.

Aos amigus sempre queridos e fonte eterna de inspiração: Haidê Malaspina, Cláudio Nadaleto,

Thumas Castilho, Kena Ferrari, Juliana Dias Galo, Ana Terra Reis, Fábio Rezende Esteves,

Antonio Carlos Homem Jr., Oliver Humberto Naves Blanco, Gastón Giné, Leonardo Ávila,

Roberto Gomes de Souza, Fabricio Sperndio, José Roberto Gomes de Paula Jr., Marcel Britto,

Victor de Abreu Zamproni, Marisa Natale, Javier Adolfo Sarria Perea, Maria Lúcia e Tkaynã. 


\section{Homem; As Viagens}

(Carlos Drummond de Andrade, 1973)

0 homem, bicho da Terra tão pequeno

chateia-se na Terra

lugar de muita miséria e pouca diversão,

faz um foguete, uma cápsula, um módulo

toca para a Lua

desce cauteloso na Lua

pisa na Lua

planta bandeirola na Lua

experimenta a Lua

coloniza a Lua

civiliza a Lua

humaniza a Lua.

Lua humanizada: tão igual à Terra.

0 homem chateia-se na Lua.

Vamos para Marte - ordena as suas máquinas.

Elas ubedecem, o humem desce em Marte

pisa em Marte

experimenta

coloniza

civiliza

humaniza Marte cum engenho e arte.

Marte humanizado, que lugar quadrado.

Vamos a cutra parte?

Claro - dizo engento

sofisticado e dócil.

Vamos a Vênus.

0 homem põe o pé em Vênus,

vê o visto - é isto?

idem

idem

idem. 
0 homem funde a cuca se não for a Júpiter proclamar justiça junto com injustiça

repetir a fossa

repetir o inquieto

repetitório.

Outros planetas restam para outras colônias.

0 espaço todo vira Terra-a-terra.

O homem chega ao Sol ou dá uma volta

só para tever?

Não-rê que ele inventa

roupa insiderável de viver no Sol.

Pũe o pé e:

mas que chato é o Sol, falso touro

espantol domado.

Restam outros sistemas fora

do solar a col-

onizar.

Ao acabarem todos

só resta ao homem

(estará equipado?)

a dificilima dangerosissima viagem

de si a si mesmo:

pôr o pé no chão

do seu coração

experimentar

colonizar

civilizar

humanizar

- homem

descobrindo em suas próprias inexploradas entrantas

a perene, insuspeitada alegria

de con-viver. 


\section{SUMÁRIO}

Índice

I- Lista de tabelas

II- Lista de fotos $\quad 15$

$\begin{array}{ll}\text { III- Lista de mapas } & 16\end{array}$

$\begin{array}{ll}\text { Resumo } & 17\end{array}$

$\begin{array}{ll}\text { Introdução } & 19\end{array}$

$\begin{array}{ll}\text { Objetivos } & 24\end{array}$

$\begin{array}{ll}\text { Hipótese } & 25\end{array}$

Capítulo 1 - CONTRADIÇÕES E MOVIMENTOS: ESPAÇO E 26 TERRITÓRIO

Capítulo 2 - ASSENTAMENTOS RURAIS E PERIFERIA 49

Capítulo 3 - DESENVOLVIMENTO HUMANO: UM SABER MÚLTIPLO 81

$\begin{array}{ll}\text { Considerações finais } & 169\end{array}$

$\begin{array}{ll}\text { Referências } & 173\end{array}$

$\begin{array}{ll}\text { Anexos } & 182\end{array}$ 


\section{ÍNDICE}

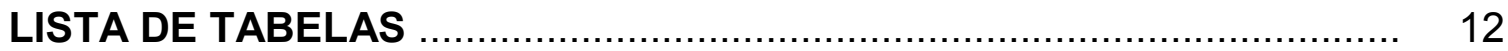

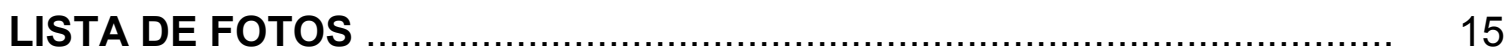

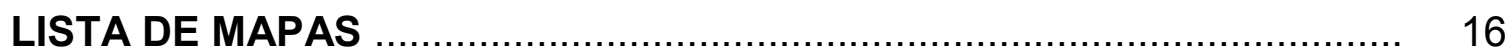

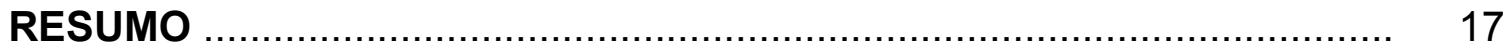

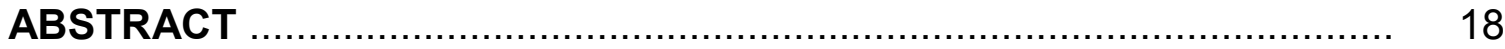

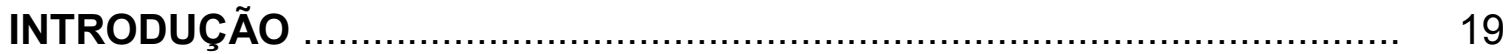

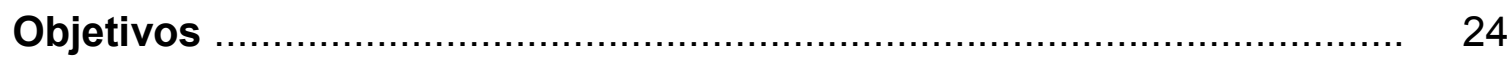

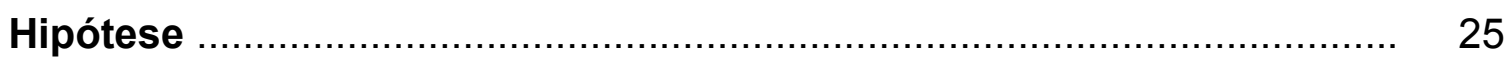

CAPÍTULO 1 - CONTRADIÇÕES E MOVIMENTOS: ESPAÇO E TERRITÓRIO ............................................................................ 26

1.1. 0 campo e a cidade .............................................................. 31

1.1. a) O campo e a cidade: indivíduo e sociedade ................................... 35

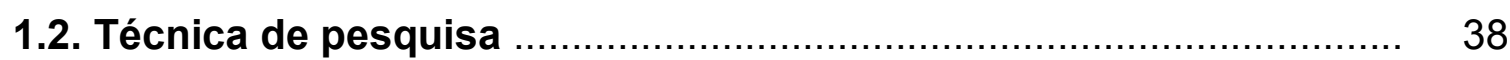

1.2. a) A espacialidade pesquisada ................................................ 38

1.2. a. 1) Assentamentos .................................................................. 39

1.2. a. 2) Periferia ............................................................................. 40

1.2. b) A elaboração do questionário ..................................................... 40

1.2. c) A composição da amostra .......................................................... 41

1.2. d) O trabalho de campo ........................................................... 43

1.2. e) Análise quantitativa e qualitativa ................................................. 47

1.2. f) Devolutiva ........................................................................ 48

CAPÍTULO 2 - ASSENTAMENTOS RURAIS E PERIFERIA ….................. 49

2.1. Ribeirão Preto - SP ................................................................... 49 
2.2. O campo: assentamentos rurais ………........................................... 56

2.2. a) Assentamento "Sepé Tiarajú" ....................................................... 60

2.2. b) Assentamento "Mário Lago" ....................................................... 65

2.3. A cidade: periferia …………….................................................. 73

CAPÍTULO 3 - DESENVOLVIMENTO HUMANO: UM SABER MÚLTIPLO 81

3.1. As dimensões do desenvolvimento humano no campo e na cidade ...... 83

3.1.1. A dimensão educação nos assentamentos e periferia ....................... 86

3.1.2. A dimensão saúde (longevidade) nos assentamentos e periferia ....... 105

3.1.3. A dimensão renda nos assentamentos e periferia ............................. 127

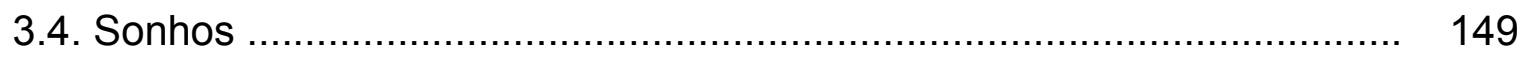

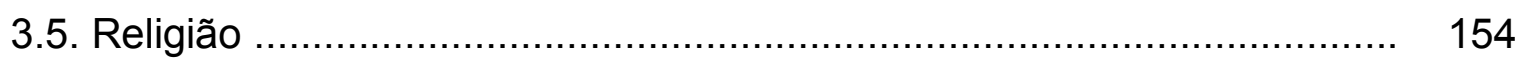

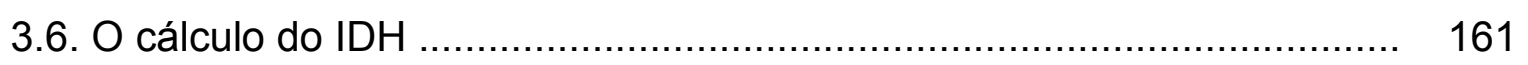

3.6.1. Para você, o que é o desenvolvimento humano? .............................. 164

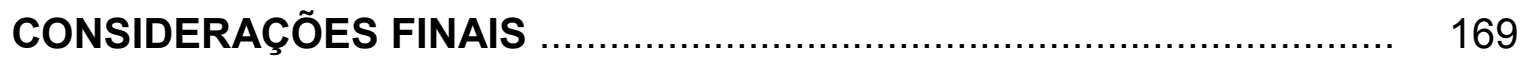

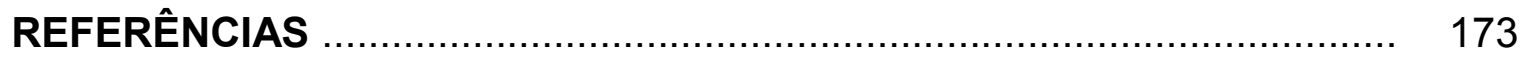

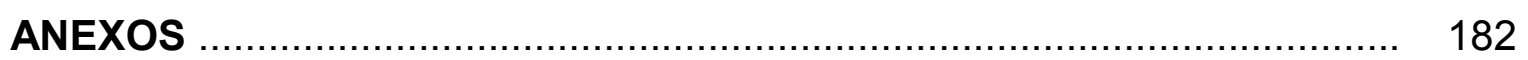




\section{LISTA DE TABELAS}

Tabela 01: Chefes de família, segundo gênero, entrevistados nos assentamentos rurais e área periférica do município de Ribeirão Preto (\%).

Tabela 02: Número médio de pessoas / família nos assentamentos rurais e área periférica do município de Ribeirão Preto (\%).

Tabela 03: Freqüência das respostas dadas à pergunta "Por que a educação é importante para o seu desenvolvimento?" nos assentamentos rurais e na área periférica urbana do município de Ribeirão Preto (\%).

Tabela 04: Idade (média) dos pais e filhos (com 15 ou mais) e respectiva média anual de escolarização nos assentamentos rurais e na área periférica urbana do município de Ribeirão Preto (\%).

Tabela 05: Cálculo do IDH-Educação baseado na taxa de freqüência à escola e percentagem da alfabetização dos assentamentos rurais e na área periférica urbana do município de Ribeirão Preto.

Tabela 06: Cálculo (referente ao ano de 2000) do IDH-Educação do município de Ribeirão Preto e municípios com maior e menor índice (IPEA, 2000).

Tabela 07: Principais motivos de abandono escolar nos assentamentos rurais e na área periférica urbana do município de Ribeirão Preto (\%).

Tabela 08: Idade média das pessoas que trabalham nos assentamentos rurais e área periférica do município de Ribeirão Preto (\%).

Tabela 09: Famílias que freqüentam bibliotecas, nos assentamentos rurais e na área periférica urbana do município de Ribeirão Preto (\%).

Tabela 10: Famílias que praticam atividades complementares nos assentamentos rurais e na área periférica urbana do município de Ribeirão Preto (\%).

Tabela 11: Idade média dos alfabetizados digitais nos assentamentos rurais e na área periférica urbana do município de Ribeirão Preto (\%).

Tabela 12: Freqüência das respostas dadas à pergunta: "Por que a saúde é importante para o seu desenvolvimento?" nos assentamentos rurais e na área periférica urbana do município de Ribeirão Preto (\%).

Tabela 13: Cálculo do IDH-Longevidade baseado na idade média dos óbitos nos assentamentos rurais e na área periférica urbana do município de Ribeirão Preto. 
Tabela 14: Cálculo (referente ao ano de 2000) do IDH-Longevidade do município de Ribeirão Preto e municípios com maior e menor índice (IPEA, 2000).

Tabela 15: Longevidade média da comunidade nos assentamentos rurais e na área periférica urbana do município de Ribeirão Preto.

Tabela 16: Motivos dos falecimentos dos pais nos assentamentos rurais e na área periférica urbana do município de Ribeirão Preto.

Tabela 17:Freqüência das respostas dadas à pergunta: "O que há de bom para fazer onde mora?" nos assentamentos rurais e na área periférica urbana do município de Ribeirão Preto (\%).

Tabela 18: Freqüência das respostas dadas à pergunta: "O que gostaria de fazer onde mora?" nos assentamentos rurais e na área periférica urbana do município de Ribeirão Preto (\%).

Tabela 19: Freqüência das respostas dadas à pergunta: "O que há de bom para ver onde mora?" nos assentamentos rurais e na área periférica urbana do município de Ribeirão Preto (\%).

Tabela 20: Freqüência das respostas dadas à pergunta: "O que gostaria de ver onde mora?" nos assentamentos rurais e na área periférica urbana do município de Ribeirão Preto (\%).

Tabela 21: Freqüência das respostas dadas à pergunta: "Por que a renda e $o$ trabalho são importantes para o seu desenvolvimento?" nos assentamentos rurais e na área periférica urbana do município de Ribeirão Preto (\%).

Tabela 22: Cálculo do IDH-Renda baseado na renda média anual per capita $(R \$)$ nos assentamentos rurais e área periférica do município de Ribeirão Preto.

Tabela 23: Cálculo (referente ao ano de 2000) do IDH-Renda do município de Ribeirão Preto e municípios com maior e menor índice (IPEA, 2000).

Tabela 24: Cálculo das despesas anuais/pessoa e \% das despesas na renda média anual/pessoa, nos assentamentos rurais e na área periférica urbana do município de Ribeirão Preto.

Tabela 25: Famílias que vivem exclusivamente com a renda da produção agropecuária nos assentamentos rurais (\%).

Tabela 26: Valores da renda média anual/pessoa, renda "não-monetária" anual/pessoa e \% renda não monetária na renda média anual/pessoa nos assentamentos rurais de Ribeirão Preto. 
Tabela 27: Cálculo do IDH-Renda baseado na renda média anual per capita ( $R \$)$, desconsiderando a renda não monetária nos Assentamentos Rurais e Área Periférica do Município de Ribeirão Preto.

Tabela 28: Beneficiários de Programas Sociais, Participação na Renda Familiar e de Beneficiários Dependentes nos assentamentos rurais e na área periférica urbana do município de Ribeirão Preto.

Tabela 29: Tipos de benefícios recebidos (\%) nos assentamentos rurais e na área periférica urbana do município de Ribeirão Preto.

Tabela 30: Sonhos nos assentamentos rurais e área periférica do município de Ribeirão Preto (\%).

Tabela 31: Freqüência das respostas dadas à pergunta: "O que você precisa para realizar seus sonhos?" nos assentamentos rurais e área periférica do município de Ribeirão Preto (\%).

Tabela 32: A diversidade religiosa nos assentamentos rurais e na área periférica urbana do município de Ribeirão Preto (\%).

Tabela 33: Tendências do índice de desenvolvimento humano no Brasil (1980-2007).

Tabela 34: Cálculo do IDH baseado no IDH-Educação, IDH-Longevidade e IDHRenda dos assentamentos rurais e área periférica do município de Ribeirão Preto.

Tabela 35: Cálculo (referente ao ano de 2000) IDH do município de Ribeirão Preto e municípios com maior e menor índice (IPEA, 2000).

Tabela 36: Freqüência das respostas dadas à pergunta: "O que é Desenvolvimento Humano para você?" nos assentamentos rurais e área periférica do município de Ribeirão Preto (\%). 


\section{LISTA DE FOTOS}

Foto 01: Moradores do bairro Jardim Aeroporto - Ribeirão Preto, SP - Abr. 2009.

Foto 02: Bairro Jardim Aeroporto - Ribeirão Preto, SP - Mai. 2009.

Foto 03: Bairro Salgado Filho 1 - Ribeirão Preto, SP - Mai. 2009.

Foto 04: Produção agroecológica - Assentamento “Sepé Tiarajú” - Mar. 2009.

Foto 05: Cotidiano no Assentamento "Mário Lago" - Fev. 2009.

Foto 06: O ponto de ônibus e/ou de encontro - Bairro J. Aeroporto - Mai. 2009.

Foto 07: O lazer, próximo ao córrego, sábado à tarde Ass. "Mário Lago" - Fev. 2009.

Foto 08: Na periferia, o lazer no final da tarde - Abr. 2009.

Foto 09: Na periferia, distintas jornadas de trabalho - Abr. 2009.

Foto 10: Anúncios: Muito trabalho! - Bairro Salgado Filho 1 - Abr. 2009.

Foto 11: Recolhendo o milho da colheita (Ass. "Mario Lago") - Fev. 2009.

Foto 12: Assentado "batendo o feijão" (Ass. "Mario Lago") - Fev. 2009.

Foto 13: O caminho está indicado. Bairro Jardim Aeroporto - Abr. 2009.

Foto 14: A polícia, a igreja e as crianças: cotidiano na periferia - Mai. 2009.

Foto 15: O menino: alegria de con-viver. (Ass. "Mario Lago") - Fev. 2009. 


\section{LISTA DE MAPAS}

Mapa 01: Região Administrativa de Ribeirão Preto.

Mapa 02: Assentamento "Sepé Tiarajú".

Mapa 03: Assentamento "Mário Lago".

Mapa 04: Área periférica urbana do município de Ribeirão Preto - setor 537.

Mapa 05: Área periférica urbana do município de Ribeirão Preto - setor 540. 


\section{RESUMO}

O trabalho apresenta uma análise qualitativa do Índice de Desenvolvimento Humano (IDH) em áreas de reforma agrária e periferia urbana de Ribeirão Preto SP. A discussão está pautada a partir dos indicadores educação, saúde e renda. Destaca-se algumas limitações do IDH - por exemplo, a "reificação" da medida em detrimento do conceito - com vistas à superação do aspecto reducionista e fragmentado do conceito de desenvolvimento adotado para o cálculo do índice. As contradições e movimentos das espacialidades pesquisadas estão descritas e revelam a dialética relação entre o par campo-cidade. Os resultados apontam novas perspectivas para a melhoria das condições de vida dos sujeitos do campo e da cidade, destacando a autonomia e alteridade como elementos fundamentais para a possibilidade da transformação social, do mesmo modo se reafirma a questão do trabalho como categoria central para o desenvolvimento humano.

PALAVRAS-CHAVE: Ribeirão Preto-SP; Índice de Desenvolvimento Humano; Assentamentos rurais; Periferia urbana. 


\begin{abstract}
This paper presents a qualitative analysis of the Human Development Index (HDI) in areas of agrarian reform and urban periphery of Ribeirão Preto - SP. The discussion is guided from the indicators education, health and income. It is detached some limitations of the HDI - for example, the "reification" of the measure at the expense of the concept - with a view to overcoming the reductionist and fragmented aspect of the concept of development adopted for calculating the index. The contradictions and movements of spatialities surveyed are described and reveal the dialectic relationship between the pair city-field. The results suggest new prospects for improving the living conditions of those in rural and urban, emphasizing the autonomy and otherness as fundamental to the possibility of social transformation, just as it reaffirms the role of labor as a central criterion for human development.
\end{abstract}

KEY WORDS: Ribeirão Preto-SP; Human Development Index; Rural settlements; Urban periphery. 


\section{INTRODUÇÃO}

Historicamente, a Organização das Nações Unidas (ONU) funciona como instrumento ideológico a serviço do capitalismo em sua potência máxima. Este processo combina progresso como barbárie e nem sempre é a realidade quem determina os dados publicados e veiculados deliberadamente pela ONU no mundo todo, especialmente, no que se refere ao Índice de Desenvolvimento Humano (IDH).

A discussão do desenvolvimento humano está diretamente relacionada às condições sociais de vida e, hoje, o Brasil, comemora sua ascensão ao "seleto" grupo dos países de alto desenvolvimento humano, ao mesmo tempo em que, ainda, demonstra sintomas concretos e recorrentes de uma realidade de profunda desigualdade (violência; fome; desemprego estrutural; degradação ambiental; etc.). Como explicar essa situação?

Se compreendermos o desenvolvimento humano enquanto uma necessidade e possibilidade de emancipação da humanidade, podemos dizer que as dimensões adotadas para a realização do cálculo oficial do índice (educação, saúde e renda), proposto pelo Programa das Nações Unidas para o Desenvolvimento (PNUD), são restritivas e com isso domesticam a percepção dos sujeitos sobre determinado estágio de desenvolvimento e também das formas de sua consolidação no território.

Procura-se, portanto a "reificação" da medida, em detrimento do conceito, a primeira considerada como determinante em um campo de formulação de políticas públicas, reforçando, assim, uma tendência de isenção de valores ideológicos e políticos, como se estes não interferissem nas opções metodológicas dos proponentes. Questões estas vinculadas à perspectiva de conceito. 
Souza (2008) afirma que categorias e conceitos, guardam em si uma dimensão qualitativa de representação ao revelarem as condições sociais que os engendram. Para o autor, os conceitos também guardam em si uma dimensão quantitativa, porém, é importante assinalar que tomados pela perspectiva positivista os conceitos normalmente adquirem sentido nominalista e, como variável, busca-se delimitar um comportamento do fenômeno, a variação em si, como foco do processo de representação da realidade humana. (SOUZA, 2008, p. 24-25)

Neste sentido, uma séria restrição do IDH consiste no fato de que o desenvolvimento entendido como "avanço e/ou progresso" é refletido exclusivamente por evoluções estritamente quantitativas dos indicadores, sem nenhuma alusão ao padrão qualitativo de desenvolvimento efetivo. De outra forma, coloca-se a necessidade de aludir-se às suas dimensões outras questões determinantes.

A dimensão educação, por exemplo, é composta por dois indicadores oficiais - onde o primeiro indica a taxa de alfabetização de pessoas acima de 15 anos de idade e o segundo, resulta de uma conta simples: a somatória do número de pessoas, independentemente da idade, que freqüentam a escola, dividido pela população na faixa etária de 7 a 22 anos - não leva em consideração a qualidade do ensino; capacidades individuais e coletivas; acessibilidade à escola; valores éticos e morais; educação ambiental; cultura; entre outros.

A dimensão saúde é avaliada, simplesmente, pela expectativa média de vida das pessoas, não avalia condições de saúde; acesso ao atendimento no sistema público e/ou privado; causa mortis; freqüência de visitas médicas; localização e 
acessibilidade ao médico; condições de saneamento; alimentação; e questões relativas ao lazer que podem proporcionar uma maior expectativa de vida.

A dimensão renda, terceira e última componente do IDH, é calculada por meio de uma fórmula específica que avalia o Produto Interno Bruto per capita e com isso não considera variáveis como: condições de trabalho; formas de ocupação e destino dos recursos da família; renda monetária, renda não monetária, "quase renda" (aluguel); articulação institucional; etc..

A valoração destas dimensões implica fundamentalmente em dar "força" ao sentido de passividade objeto-sujeito que se quantifica, indicando qual é o número do desenvolvimento. Não se consolida uma perspectiva do sujeito capaz de revelar seu grau de envolvimento na consolidação das condições existentes ou de uma condição desejada. Esta dimensão do sujeito, em verdade, é reveladora de uma lógica em que as políticas públicas que alteram efetivamente sua condição de vida não são recebidas, mas demandadas. Um processo que aponta para o sujeito a apreensão de um conceito, para além de sua métrica, mas projetada nas condições materiais e objetivas de sua realidade.

Com isso, uma avaliação das condições de vida feita por meio do cálculo do Índice de Desenvolvimento Humano (IDH), considerando seu papel como indicador das formas de produção e reprodução da vida, deve projetar-se para além do campo métrico. Reconhecendo elementos qualitativos determinantes para o desenvolvimento ou sua consecução. Não obstante, observa-se que a perspectiva do sujeito ainda deve incorporar seus campos de autonomia, alteridade, inserção social, condição organizativa e atuação política. 
Neste caso, uma perspectiva de eqüidade e de sustentabilidade deve ser assumida quando se discute os impactos das condições de vida de determinada sociedade, trabalhando-se para além dos pressupostos de uma única dimensão deste desenvolvimento, quer seja econômica, social, política, ambiental, entre outras.

Esta dialética relação entre elementos subjetivos e objetivos que compõem a realidade em rápido movimento nos conduzirá, em nossa pesquisa, aos conceitos e categorias que são de fundamental importância para a compreensão do desenvolvimento humano.

Desta feita, desenvolvemos uma pesquisa acerca dos indicadores de desenvolvimento humano junto às áreas de periferia urbana e assentamentos rurais no município de Ribeirão Preto-SP. Conhecida como a "Capital do Agronegócio", o município ao mesmo tempo em que se apresenta com um indicador de alto desenvolvimento humano, revela também uma combinação factual do progresso como barbárie em seu cotidiano.

O Instituto Brasileiro de Geografia e Estatística (IBGE) indica que a população do município de Ribeirão Preto em 2008, seria de 558.136 habitantes, sendo que deste total, segundo o Instituto de Pesquisa Econômica Aplicada (IPEA), cerca de 11.961 famílias vivem com menos de R\$120,00/pessoa/mês. Considerando o número médio de quatro pessoas por família isso significa dizer que 47.844 habitantes, ou $8,57 \%$ da população do município sobrevivem com menos de $R \$ 4,00$ por dia. Esta relação de desigualdade profunda entre os mais ricos (da zona sul) e os mais pobres (da zona norte) não está expressa nos dados publicados acerca do desenvolvimento do município, especialmente no que se refere ao IDH, que em 
2000, apresentou-se igual a 0,855 , valor considerado alto, como mencionado anteriormente.

Assim sendo, pretendemos no decorrer do texto apresentar determinadas limitações do índice, bem como propostas para superar esta perspectiva externa ao sujeito no que tange ao desenvolvimento humano.

O trabalho está estruturado em cinco seções, incluindo esta introdução. No capítulo 1 "Contradições e movimentos: espaço e território" discutiremos a respeito dos conceitos espaço e território, bem como sobre a relação campo-cidade, baseados principalmente na superação da dicotomia deste par. Além disso, apresentaremos a técnica de pesquisa utilizada neste trabalho.

No capítulo 2 "Assentamentos Rurais e Periferia" faremos uma discussão sobre o desenvolvimento do município de Ribeirão Preto-SP e seu entorno e então apresentaremos os assentamentos rurais: "Sepé Tiarajú" e "Mário Lago" e a área periférica urbana, que compreende parte dos bairros Jardim Aeroporto e Salgado Filho 1, no município de Ribeirão Preto.

Finalmente, no capítulo 3 "Desenvolvimento Humano: um saber múltiplo" faremos uma reflexão acerca das três principais dimensões que compõem o Índice de Desenvolvimento Humano (IDH) - educação, saúde e renda. Neste momento, procuraremos apontar os limites do índice e demarcar outros elementos que superem a perspectiva quantitativa do índice.

Nas considerações finais, reafirmaremos a questão do trabalho como categoria central para o desenvolvimento humano, ao mesmo tempo em que, verificaremos que nos bairros de periferia, há uma diluição dessa centralidade, apontando para o consumo como valor determinante da reprodução social. 


\section{Objetivos}

“... objetivo é vivermos melhor. A economia é apenas um meio.

O nosso avanço para uma vida melhor é que deve ser medido..."

(DOWBOR, L. 2009)

O objetivo é verificar como se comportam os indicadores de Desenvolvimento Humano em áreas de reforma agrária e periferia urbana em Ribeirão Preto, SP e analisar como os aspectos de ordem qualitativa, tanto objetivos como subjetivos, complementam o conceito de qualidade de vida, traçando assim, os indicadores para além das estatísticas e dos números, ou seja, para além da pobreza material, o foco está na trajetória da vida futura dessas pessoas, em sua capacidade de organização, em sua percepção sobre sua realidade material e imaterial, consolidando, portanto, dimensões subjetivas/objetivas do território. E desta forma, estabelecer uma relação entre as diferentes perspectivas dos indicadores, evoluindo para uma discussão crítica que traduza a alteridade bem como a autonomia em instrumentos de intervenção para a transformação social.

Como objetivos específicos podemos destacar:

Caracterizar e analisar as áreas de estudo (Assentamentos Rurais: Mário Lago - Ribeirão Preto - SP e Sepé Tiarajú - Serra Azul - SP; Área Periférica Urbana: Bairros Jardim Salgado Filho 1 e Jardim Aeroporto - Ribeirão Preto - SP)

Apresentar os cálculos dos indicadores que compõem o IDH no campo e na cidade, conjuntamente à avaliação do índice - quantitativa e qualitativamente; 
Analisar e interpretar criticamente os resultados apresentados sob a perspectiva qualitativa da qualidade de vida e, identificar as diferenças qualitativas das espacialidades pesquisadas.

\section{Hipótese}

A hipótese central do trabalho é que o Índice de Desenvolvimento Humano (IDH) apresenta limitações sobre a compreensão do processo de formação qualitativa do desenvolvimento e que esta perspectiva é engendrada pela dimensão organizativa e reflexiva do sujeito sobre sua realidade, sobre suas condições de reprodução social. Essa materialidade é que consolida concepções subjetivas de qualidade e desenvolvimento. 


\section{CAPÍTULO 1}

\section{CONTRADIÇÕES E MOVIMENTOS: ESPAÇO E TERRITÓRIO.}

A discussão a respeito da categoria filosófica espaço é bastante complexa e envolve diferentes perspectivas e métodos para a compreensão e composição dessa matéria. Além disso, pressupõe-se que uma concepção idealista não é suficiente para trabalhar essa categoria. Kant (2001) define o espaço como uma categoria da intuição, onde, o espaço não é uma materialidade, mas sim uma forma de perceber os fenômenos, "espaço nesse sentido, não é uma realidade objetiva externa ao sujeito, mas é um elemento da capacidade cognitiva do próprio sujeito".

Nesta abordagem idealista do espaço, não é possível apreender as contradições, conflitos e os movimentos que fazem parte, intrinsecamente, da dimensão espacial da realidade e também com isso perceber o quanto as dimensões subjetivas estão ligadas às dimensões objetivas.

Quando, em uma perspectiva de realidade objetiva, Lefebvre (1974) propõe que "as práticas espaciais regulam a vida - não a criam", o autor avança para uma abordagem ideológica-política muito clara, ou seja, para o autor, "o espaço não tem poder em si mesmo, nem o espaço enquanto tal determina as contradições espaciais. Estas são contradições da sociedade - contradições entre uma coisa e outra no interior da sociedade, como por exemplo, entre as forças e as relações de produção - que simplesmente emergem no espaço, ao nível do espaço, e assim engendram as contradições do espaço" (LEFEBVRE, 1974) 
O espaço se dá, neste caso, por condições objetivas e subjetivas que compõem uma realidade multidimensional e desta forma reforça a natureza contraditória do espaço geográfico.

Nas circunstâncias atuais, tal como expresso por Santos (1994:39), o espaço geográfico constitui "um sistema de objetos e um sistema de ações" que: é formado por um conjunto indissociável, solidário e também contraditório, de sistemas de objetos e sistemas de ações, não considerados isoladamente, mas como "um quadro único na qual a história se dá". No começo, para o autor, era a natureza selvagem, formada por objetos naturais, que ao longo da história vão sendo substituídos por objetos fabricados, objetos técnicos, mecanizados e, depois cibernéticos fazendo com que a natureza artificial tenda a funcionar como uma máquina.

Logo, percebe-se que, ainda que o autor caracterize de forma dual a natureza (selvagem/artificial), à luz da discussão de Marx (1980:50), deve-se entender "o trabalho como criador de valores-de-uso, como trabalho útil, sendo indispensável à existência do homem - quaisquer que sejam as formas da sociedade - sendo a necessidade natural e eterna de efetivar o intercâmbio material entre o homem e a natureza e, portanto, de mantença da vida humana".

Nesse sentido, torna-se fundamental aprofundar a discussão sobre o espaço geográfico, a fim de compreender melhor as contradições e movimentos de nossa sociedade e com isso estabelecer uma relação entre seu desenvolvimento e qualidade de vida.

Moreira (1985) define o espaço como "a materialidade do processo do trabalho". E acrescenta que, o espaço é a "relação homem-meio" na sua expressão 
historicamente concreta, mas ainda assim o autor repercute o dualismo apresentado por Santos (1994) anteriormente, quando afirma que "é a natureza, mas a natureza em seu vaivém dialético: ora a primeira que se transforma em segunda, ora mais adiante a segunda que reverte em primeira, para mais além voltar a ser segunda (MOREIRA, 1985, p.86). Não levando em consideração que é intrínseco à natureza humana realizar transformações em seu espaço habitado, especialmente, por meio do trabalho que não é estranho ao homem, pelo contrário, essencial a ele.

Por sua vez, cabe considerar que há uma necessidade de superar esta perspectiva de pensar a natureza primeira e a segunda, e mesmo sua "reconstituição" como primeira, pois isto reforça um modelo mecanicista da trilogia tese-antítese-síntese. Ou seja, esta reflexão deve vir no sentido da concepção do homem como natureza reflexiva, sobre si e sobre o espaço. Uma perspectiva reflexiva que opera sobre materialidades e imaterialidades, produzindo territórios.

Nota-se aqui materialidade e imaterialidade como processos históricos, ainda que diferentes, estão em unidade, isto é, há identidade concreta de sua gênese, bem como acontece com o par dialético concreto e abstrato. Fato o qual se torna evidente para Lefebvre (1995) quando destaca que "entre a forma e o conteúdo se opera, assim uma interação e um movimento incessantes", tal como ocorre ao desenvolvimento humano, mas que nesse caso é expresso por concreto/abstrato objetivo/subjetivo.

Mas o que importa, concordando com o autor, "antes de mais nada, é encontrar as relações, as transições, a ligação interna e necessária de todos os elementos, de todas as partes do pensamento, bem como da realidade em desenvolvimento que é analisada" (LEFBVRE, 1995). 
Assim sendo, a transformação do espaço, principalmente, econômica e política para Raffestin (1993) traz como fruto de um processo histórico o território, que pode ser composto, decomposto (desterritorializado) e recomposto (reterritorializado) historicamente (MOREIRA, 2006). Compreende-se, neste momento, que para o território existir, de fato, é necessário que o conteúdo das relações sociais esteja presente, conteúdo este entendido aqui como: relações de poder, redes de circulação e comunicação, identidades simbólicas e culturais e também a natureza exterior ao homem.

Em realidade, a perspectiva mecânica tese-antítese-síntese dada ao espaço/território não define a gênese dessas alterações, que nesta análise é o próprio trabalho e suas formas de apropriação concreta e simbólica exercidas pelas relações capitalistas de produção que as definem.

Heidrich (1998), ao referir-se à constituição do território, diz que "a diferenciação do espaço em âmbito histórico tem início a partir da delimitação do mesmo, isto é; por sua apropriação como território; em parte determinado pela necessidade e posse de recursos naturais para a conquista das condições de sobrevivência, por outra parte, por sua ocupação física como habitat. Neste instante, na origem, a defesa territorial é exercida diretamente pelos membros da coletividade. Noutro extremo, como já ocorre desde a criação do Estado, quando há população fixada territorialmente e socialmente organizada para produção de riquezas, cada indivíduo não mantém mais uma relação de domínio direto e repartido com o restante da coletividade sobre o território que habita. Neste momento, a defesa territorial passa a ser realizada por uma configuração social voltada exclusivamente para a organização e manutenção do poder" (HEIDRICH, 
1998). Embora se reconheça as intrínsecas relações território/poder, o autor de forma subliminar naturaliza a dimensão do território como habitat e não supera a perspectiva de território/nação como sua representação.

Para Oliveira (2007), o centro fundante do conceito de território é: o poder e a possibilidade de seu exercício sobre uma fração do mundo. O poder de ser e estar em um ponto ou outro desta fração do mundo. Esta existência (ser/estar) das práticas sócio-espaciais é determinante para a materialização de diferentes formas de apropriação existentes no mundo. Um processo eminentemente sócio-histórico. Em vista disso, de acordo com o autor, é que se parte, portanto, da concepção (OLIVEIRA, 1999) de que o território deve ser apreendido como síntese contraditória, como totalidade concreta (modo de produção/distribuição/circulação/consumo) e suas articulações e mediações supraestruturas (políticas, ideológicas, simbólicas, etc.). Processos onde o Estado, no atual estágio de desenvolvimento do capitalismo, desempenha a função de regulação desse efetivo exercício.

Mas de qual Estado regulador se faz referência? A dimensão de classe sintetiza esta perspectiva, não apenas pela compreensão burguesa de Estado expressa nas análises de Engels e Marx em "Origem da Propriedade Privada e do Estado" (1981), e XVIII Brumário (1969), ou Crítica ao Programa de Gotha (1965), mas sobretudo pela antiteticidade das organizações sociais (LUKÁCS, 1979).

Oliveira (2008) indica que "o território é assim, produto concreto da luta de classes travada pela sociedade no processo de produção de sua existência. Dessa forma, são as relações sociais de produção e o processo contínuo/contraditório de desenvolvimento das forças produtivas que dão a configuração histórica específica 
ao território. Logo, para o autor, o território não é um prius ou um a priori, mas, a contínua luta da sociedade pela socialização igualmente contínua da natureza (OLIVEIRA, 2008, p.5).

Por fim, vale ressaltar que esta transformação do espaço, este processo de apropriação do território (ocupação, cultivo, relações sociais e relações de poder) ocorre por meio de uma relação do homem com a natureza que, se mediada por uma práxis crítica revolucionária, em contraposição a uma práxis fetichizada pelo homem, rompe com paradigmas de desenvolvimento e modernização e avança em uma conduta anti-hegemônica que emancipa e amplia as condições para que o desenvolvimento humano ocorra de forma concreta seja no campo ou na cidade.

\section{1. $O$ campo e a cidade}

As alterações recentes na configuração territorial, em diferentes escalas, nos desafiam a realizar uma leitura objetiva da realidade, em uma perspectiva crítica que inclua as relações contraditórias do campo e da cidade.

Compreender a questão campo-cidade vai além de uma simples pergunta e de um mero problema da Geografia. Os conceitos de campo e cidade ora se aproximam, ora se distanciam, formando assim uma "unidade dialética" (OLIVEIRA, 1993) e este movimento se estabelece como concretude humana e somente a partir dela se concebe como espacialidade e sua compreensão é reveladora do método, que concebe a realidade produzida profundamente como desigual e a superação da dicotomia campo-cidade é assim iminente. Para esta questão é preciso estabelecer 
um diálogo constante entre esta unidade contraditória e a realidade em rápido movimento.

Neste sentido, as discussões no plano teórico-conceitual sobre a problemática campo-cidade, devem ser feitas de forma crítica e não reducionista. Destaca-se aqui a relevância de empreender análises que reconheçam nas dimensões econômica, política e social, as contradições do desenvolvimento do capitalismo que permeiam a relação campo-cidade.

Hoje, contudo, essa discussão ainda aparece de forma fragmentada, inviabilizando, de certa forma, uma reflexão mais aprofundada que avance no sentido de uma re-elaboraração dos conteúdos de campo, cidade, urbano e rural.

Para Lefebvre (1991: 66) a relação campo-cidade mudou profundamente no decorrer do tempo histórico, segundo as épocas e os modos de produção: ora foi profundamente conflitante, ora mais pacífica e perto de uma associação, mas esse movimento só pode ser apreendido à luz dos papéis e funções que tais dimensões espaciais assumiram/assumem no desenvolver dos modos de produção e reprodução social humana.

Carlos (2004) destaca que o campo e a cidade se diferenciam pelo conteúdo das relações sociais neles contidas e estas, hoje, ganham conteúdo em seu conjunto com a construção da sociedade urbana, não transformando o campo em cidade, mas redefinindo o conteúdo da contradição campo-cidade, bem como aquilo que Ihes une (CARLOS, 2004, p.9). Neste caso, como afirmou Spósito (2006:116) não é importante distinguir ou diferenciar os dois espaços, mas compreender seus sentidos e papéis, assim como analisar as relações políticas econômicas e os 
valores culturais que, em cada espaço-tempo, orientam as articulações entre campo e cidade.

Desta forma, Oliveira (2004) destaca que em o Novo Rural Brasileiro Graziano da Silva (1999) revalida que o desenvolvimento do modo capitalista de produção trouxe consigo o desenvolvimento e a expansão do urbano e, o urbano tornou-se assim maior que a cidade e o campo, tornou-se sua síntese contraditória. Neste caso, na opinião do autor, a dimensão "rurbana" proposta por Graziano da Silva, não se constitui na síntese de contrários mas uma leitura de atividades produtivas diversas (produção, circulação e consumo e suas representações) que se realizam sobre a mesma espacialidade, mas que não não supera função e forma, a partir do momento que não explicita o território em disputa pelos seguimentos sociais. Como salientou Oliveira (2004) esta síntese “contraditória”, não eliminou a cidade nem o campo. Um não pode ser entendido sem o outro. (OLIVEIRA, 2004, grifo nosso, p 44).

Ainda de acordo com Oliveira (2004:41) "a lógica do desenvolvimento do modo capitalista de produção é gerada pelo processo de produção propriamente dito, circulação, valorização do capital e a reprodução da força de trabalho e é nessa lógica contraditória que constrói/destrói formações territoriais em diferentes partes do mundo". Nota-se aqui, que as novas territorialidades estão adequadas ao capital e não aos trabalhadores.

Os espaços urbanos, por exemplo, não se articulam entre si através de uma especialização funcional, mas se superpõem, seguindo a complexidade industrial em sua ordem e grandeza (SANTOS,1982). Esta lógica é a base da urbanização comandada pela industrialização. 
Para entender-se esta dialética relação é preciso compreender a problemática em suas múltiplas determinações. As relações existentes entre campo e cidade tornam-se mais intensas, não apenas no aspecto econômico, mas também no político e social, lembrando que estas dimensões devem ser sustentadas como indissociáveis, estas espacialidades apresentam convergências e antíteses, no amplo espectro de conflitos das classes sociais amalgamadas pelas relações econômicas intersetoriais. Mediações capitalistas que promovem a subsunção do trabalho e nesta lógica que se apresentam convergentes e diferem quanto a dinâmica de transferência de renda e da estrutura do monopólio da terra, mas que paulatinamente se equilibram, dado o grau de avanço do capital monopolista no campo (SOUZA, 2007) .

O que se vê no processo de "modernização da agricultura", não é diferente, pois traz consigo uma mudança de padrão tecnológico e da matriz produtiva do campo que aumenta o grau de dependência entre os setores da cidade e do campo, impondo uma homogeneização da produção. Fato o qual remete o pensamento diretamente ao altíssimo grau de devastação das áreas verdes e ao comprometimento da vida de várias espécies da fauna e flora em todos os territórios do planeta.

Para tais enfrentamentos, no campo, destacam-se os movimentos sociais que atuam em defesa e respeito da Terra, em uma luta que se amplia diariamente contra o sistema que privilegia tão poucos. Ligando-se à cidade por uma consciência de classe, que é despertada pelos sindicatos, pelas organizações, pelos movimentos que lutam por moradia, os quais também enfrentam as mazelas sociais, 
reivindicando, protestando e atuando para o rompimento das amarras que o capital impõe aos territórios urbanos e rurais (BELLENTANI e SOUZA, 2006).

Para continuarmos com esse raciocínio, é necessário ressaltar que no caso brasileiro, como afirma Oliveira (2004) esse processo histórico, ao mesmo tempo em que aprofunda a luta pela reforma agrária no campo (o aumento da violência é uma evidência desse processo), transfere paulatina mas decididamente essa luta (pela reforma agrária) para as cidades.

\section{1. a) O campo e a cidade: indivíduo e sociedade.}

Para Freire "o homem integrado é o homem Sujeito" (FREIRE, 1980), isto é, um homem enraizado não só historicamente, mas acima de tudo aquele que expressa a sua humanização, exercita sua liberdade, assume as tarefas de seu tempo, reflete e analisa-as, posicionando-se criticamente e tomando decisões que interferem e alteram a realidade. Entretanto, o homem poderá situar-se em outro pólo - o da adaptação e o da acomodação - onde existirá como objeto: coisificado, desenraizado, desumanizado (OSOWSKI, 2008, p.394).

De acordo com Carlos (2004) tudo o que diz respeito às condições de vida do homem se deteriora e o mundo produzido torna-se exterior ao homem, desenraizamno, ligam-no à subjetividade produzida dentro do mundo da mercadoria

Assim a cidade e o campo estão atravessados por novos objetos que vão dominando a vida cotidiana. Ainda para a autora, a extensão dos limites e possibilidades da realização do capital produziu, tendencialmente, o espaço enquanto valor de troca, objeto de valorização (CARLOS, 2004, p. 11). 
Por exemplo, no caso da transformação do espaço em mercadoria, Carlos (2004, p.4) afirma que, os terrenos vazios na cidade e a terra improdutiva no campo, têm em comum o fato de que funcionam como reserva de valor, possibilidade de realização da renda da terra (no campo) e da valorização do valor na cidade através da produção do espaço - em ambos os casos revelam a extensão do mundo da mercadoria enquanto realização da lei do valor no espaço, entrando em conflito com a apropriação e produzindo uma imensa população sem terra para plantar e sem um teto para morar, obrigando a invenção de estratégias sempre renovadas de vida.

Esta transformação do espaço em mercadoria e do sujeito em objeto é patente tanto no campo quanto na cidade. Agora, quando os sujeitos ("ser integrado") negam esta decomposição do espaço em mercadoria, negam também a possibilidade de redução dos sujeitos a objetos, pois consolidam desta maneira uma lógica diversa, que aponta para a resistência e produz conseqüências que alcançam toda a sociedade.

Conseqüências/estratégias estas, de resistência, que ratificam que essa relação sujeito-objeto não está dada de maneira inexorável, re-afirmando assim uma perspectiva de transformações seja no campo, seja na cidade, pois conforme Freire (1980) o homem é um ser inacabado, sempre em movimento.

Para Santos (2007) com a difusão dos valores distorcidos da modernidade, valores que são freqüentemente dados como se fossem valores urbanos, a teia de relações outrora instalada nas cidades praticamente se estende por toda a parte, com a industrialização e a "modernização do campo". Os constrangimentos que se opõem a uma plena realização do sujeito e da vida social estão em toda a parte. 
Como resposta na busca dos direitos perdidos, a procura do novo cidadão deve se dar em toda a parte e não só na cidade (SANTOS, 2007).

Estas questões, como ressalta Carlos (2004) apontam na direção da necessidade de colocar a "reprodução da sociedade" no centro do debate o que revelaria o conteúdo da prática sócio-espacial, mudando o conteúdo das relações cidade-campo. Nesta direção, a autora indica que o mundo rural não estaria desaparecendo, englobado pelo desenvolvimento das cidades, nem o campo ampliando seu domínio, apontando para um Brasil "menos urbano do que se calcula" (CARLOS, 2004, p.9), a lógica não está nas espacialidades em si, mas nos dinamismos da reprodução sócio-espacial (que são determinantes para a hegemônica forma de reprodução capitalista) que as ensejam.

A dinâmica de reprodução sócio-espacial revela assim as trajetórias dos sujeitos sociais e evidencia seus graus de apropriação territorial e suas articulações de classe. Esse dinamismo aponta aos trabalhadores condições concretas de existências urbanas e rurais, existências que se mesclam, capazes de gerar territórios ou de sub-existir neles, diferenciando e constituindo homens, ora como sujeitos, ora como objetos. Sobre estas existências que nos debruçamos.

Por último, deve-se deixar claro que colocar o conhecimento científico a serviço da transformação e da justiça social é um compromisso que deve ser assumido no interior da prática universitária. Conforme apontamos anteriormente, a re-definição e/ou re-conceituação do campo e da cidade, enquanto uma unidade dialética é fundamental, desde que seja feita a partir da leitura da realidade e entendida em suas múltiplas determinações, a fim de evitar que a capacidade reflexiva dos sujeitos seja categoricamente fragmentada, ou apenas idealista 
apresentada (para aqueles que disputam os conceitos como se a realidade fosse ali engendrada).

\subsection{Técnica de pesquisa}

“... O marxismo permitiu compreender que os fatos humanos são instituições sociais e históricas produzidas não pelo espírito e pela vontade livre dos indivíduos, mas pelas condições objetivas nas quais a ação e o pensamento humanos devem realizar-se..."

(CHAUÍ, 2000)

\section{2. a) A espacialidade pesquisada}

Diante da excessiva divulgação referente ao desenvolvimento e à qualidade de vida em Ribeirão Preto-SP, questionamos: sobre qual desenvolvimento refere-se esta propaganda? Particularmente, esses anúncios são veiculados, por um setor do agronegócio, envolvendo grandes grupos empresariais que concentram as terras do país; dissimulam sua destruição da natureza pelo discurso ecológico e sustentável; esquivam-se de suas responsabilidades fiscais e legais (SOUZA, 1998; 2008); além de fazer convergir, leis e medidas provisórias em favor de muito poucos proprietários rurais.

Nesse sentido, definimos para a pesquisa um recorte espacial que envolve a cidade e o campo do município de Ribeirão Preto, conhecida como a "Capital do Agronegócio". Consideramos as dimensões objetivas/subjetivas que permeiam as relações capitalistas de produção e que transcendem o território administrativo do município de Ribeirão Preto. Ou seja, nesta lógica, a espacialidade do agronegócio, pautado especialmente pela hegemonia do setor sucroalcooleiro, se estende para além dos limites administrativos, o que nos levou a considerar também para a 
pesquisa, o assentamento rural de reforma agrária que está localizado entre os municípios de Serrana e Serra Azul-SP (“Sepé Tiarajú”).

Nesta lógica, as áreas rurais, de assentamentos da reforma agrária, foram definidas dada ou não a sua circunscrição geográfica ao município, permitindo comparar o entorno rural que aproxima as histórias de vida e ocupação territorial destes sujeitos enquanto organização e antítese ao modelo hegemônico de apropriação territorial presente.

Quanto à área urbana estudada, esta foi determinada em função dos índices de renda, segundo a base de dados do Instituto Brasileiro de Geografia e Estatística (IBGE), 2000, que aponta os setores censitários escolhidos como os mais baixos níveis de renda de Ribeirão Preto.

\section{2. a. 1) Assentamentos}

$\checkmark$ O assentamento "Sepé Tiarajú" que se localiza entre os municípios de Serrana e Serra Azul é fruto de uma trajetória de ocupações realizadas pelo Movimento dos Trabalhadores Rurais Sem Terra - MST. Em agosto de 2003 a área de 797 ha foi comprada do governo do estado de São Paulo pelo Instituto Nacional de Colonização e Reforma Agrária (INCRA) e em 2004 saiu a Portaria $n^{\circ}$ 46/INCRA que deu inicio ao processo de assentamento de 80 famílias no local.

$\checkmark$ O assentamento "Mário Lago" está localizado no município de Ribeirão Preto e foi em maio de 2007 que o Tribunal Regional Federal da $3^{a}$ Região concedeu a imissão de posse da Fazenda da Barra ao INCRA. A área tem 1.790,80 hectares e hoje conta com 420 famílias assentadas, lembrando que 
na área encontram-se dois movimentos de luta pela terra: Movimento dos Trabalhadores Rurais Sem Terra - MST (264 famílias) e Movimento de Libertação dos Sem Terra - MLST (116 famílias); além de uma associação independente de trabalhadores rurais, intitulada "Índio Galdino" (44 famílias).

\section{2. a. 2) Periferia}

$\checkmark$ A área de periferia estudada refere-se, particularmente, a dois setores (537 e 540) que compõem o sub-setor Norte 13 do município de Ribeirão Preto, definição dada pelo Instituto Brasileiro de Geografia e Estatística (IBGE) Ribeirão Preto. Fazem parte desses dois setores parte dos bairros Jardim Aeroporto e Jardim Salgado Filho 1. Hoje, o setor 540 compreende 383 domicílios enquanto que no setor 537 são 315, contando com 698 domicílios no total.

\section{2. b) A elaboração do questionário}

O questionário para Avaliação do Índice de Desenvolvimento Humano (IDH) em assentamentos rurais e áreas periféricas urbanas, foi elaborado a partir dos seguintes indicadores: educação, longevidade e renda, de maneira que o diagnóstico tivesse caráter quantitativo e qualitativo (Anexo 01).

Ressalta-se ainda que para a definição das questões houve uma evidente preocupação com a perspectiva que as famílias apresentam acerca do desenvolvimento humano e como estes sujeitos revelam-se em meio às contradições da realidade em que vivem. 
Ainda que a consolidação de uma leitura que ultrapasse a perspectiva do IDH tenha sido realizada a partir dos conceitos propostos pelo nosso trabalho (abandono escolar; alfabetização digital; lazer; renda não monetária; entre outros) estes apresentaram significância para os sujeitos e diferencialidade sobre as espacialidades de análise.

\section{2. c) Composição da amostra}

Com o objetivo de recolher e registrar, de maneira ordenada, os dados sobre o Índice de Desenvolvimento Humano nos assentamentos rurais foram entrevistados 10\% do total de 500 famílias, sendo que 420 famílias estão no Assentamento "Mário Lago" e outras 80, no assentamento "Sepé Tiarajú". Assim como nos bairros da periferia de Ribeirão Preto, especialmente Jardim Salgado Filho 1 e Jardim Aeroporto, que compõem a maior parte do sub-setor norte 13 (n-13); contando com 698 domicílios, 70 deles foram entrevistados, totalizando a amostra exploratória de $10 \%$.

Os questionários foram aplicados aos chefes das famílias, homens e mulheres, com uma média de idade no Assentamento Mário Lago de 50 anos e no Assentamento Sepé Tiarajú de 52 anos. Na periferia Sub-Setor Norte 13 a média de idade dos respondentes foi de 44 anos.

No Assentamento Mário Lago a percentagem de respondentes homens foi de $37,5 \%$ e mulheres $62,5 \%$, no Sepé Tiarajú $45,2 \%$ homens e $54,7 \%$ mulheres que responderam ao questionário. Na periferia este valor ficou em torno de $48,5 \%$ homens e 51,4\% mulheres (Tabela 01). 
Tabela 01: Chefes de família, segundo gênero, entrevistados nos Assentamentos Rurais e Área Periférica do Município de Ribeirão Preto (\%).

\begin{tabular}{lcc}
\hline LOCAL & Homens & Mulheres \\
\cline { 2 - 3 } Ass. Mario Lago & 37,50 & 62,50 \\
Ass. Sepé Tiarajú & 45,23 & 54,76 \\
\cline { 2 - 3 } Área periferia (n-13) & 48,57 & 51,42 \\
\hline
\end{tabular}

Fonte: Trabalho de Campo Fev - Jun 2009.

Organização: Natália Freire Bellentani

A determinação do gênero, por vezes, pode nos trazer indicativos interessantes em relação as múltiplas dimensões propostas pelo trabalho para avaliar a qualidade de vida e o desenvolvimento humano, como será possível verificar durante a discussão dos resultados.

Nos assentamentos rurais o número médio de pessoas por família variou entre uma a três pessoas mais de $70 \%$ no Assentamento Mário Lago, 37,50\% para o Assentamento Sepé Tiarajú e na periferia uma média de $49,3 \%$. De quatro a sete pessoas no Assentamento Mário Lago pouco mais de $20 \%$ e no Sepé Tiarajú $50 \%$, na periferia esse valor esteve em torno de $47 \%$. De oito a onze pessoas na família, moradores no domicílio e/ou barraco no Assentamento Mário Lago em torno de 7\%, no Sepé Tiarajú, $12,5 \%$ e na periferia cerca de 2,8\% (Tabela 02). 
Tabela 02: Número médio de pessoas / família nos Assentamentos Rurais e Área Periférica do Município de Ribeirão Preto (\%).

LOCAL

Pessoas/Família (\%)

\begin{tabular}{ccc}
\hline $\mathbf{1 - 3}$ & $\mathbf{4 - 7}$ & $\mathbf{8 - 1 1}$ \\
\hline 71,42 & 21,42 & 7,14 \\
37,50 & 50,00 & 12,50 \\
\hline 49,33 & 47,82 & 2,85 \\
\hline
\end{tabular}

* referência utilizada pelo IBGE para designar o sub-setor Norte 13 (n-13).

Fonte: Trabalho de Campo Fev - Jun 2009.

Organização: Natália Freire Bellentani

\section{2. d) O trabalho de campo}

Definidos nossos objetivos, a coleta de dados quantitativos e qualitativos sobre o desenvolvimento humano nas áreas de periferia e assentamentos rurais, foi realizada entre os meses de fevereiro e junho de 2009.

As declarações foram fielmente anotadas, não havendo a necessidade de gravador. As perguntas foram feitas de acordo com os objetivos da pesquisa e a linguagem utilizada com os entrevistados variou em função não só do nível de escolaridade dos mesmos, mas também das especificidades subjetivas/objetivas de cada lugar pesquisado - sempre respeitando as diferenças e características particulares dos domicílios e ou lotes visitados.

Nesse momento cabe aqui remeter ao conceito geográfico de lugar sob uma perspectiva crítica (ainda que este não seja o centro de nosso processo investigativo) tendo em vista que determinados elementos subjetivos/objetivos do modo de vida dos sujeitos foram expressos e manifestados de forma concreta 
durante o trabalho de campo. Determinadas características específicas do cotidiano desses sujeitos nos revelaram a forma com que eles resistem ou submetem-se ao processo homogeneizador do sistema econômico. Portanto, também nos utilizamos deste conceito para procurar entender tais processos específicos.

As idas/vindas e permanências tanto na periferia quanto nos assentamentos nos permitiu observar de maneira mais detalhada as relações sociais que estabelecem-se e a forma com que manifestam-se nesses lugares e com isso formam os territórios estudados, além de promover nossa aproximação às diferentes realidades com as quais deparamo-nos e com isso poder aproximar-nos das famílias, sem que esses sujeitos estranhassem-nos e assim emprestassem-nos sua atenção, com a qual conseguimos realizar o trabalho de campo.

O fato de caminharmos juntos trouxe-nos a possibilidade de compreendermos parte da realidade em que vivem. Nos ônibus, nas vãs (no caso dos assentamentos) e/ou a pé, as conversas eram livres e despreocupadas, os "causos" eram contados tranquilamente pelos moradores que muitas vezes não eram entrevistados (formalmente), mas que contribuíram para que nossa chegada em cada casa ou barraco não gerasse qualquer tipo de estranhamento (Foto 1).

Os hábitos cotidianos, a forma de dizer, os medos e anseios de cada lugar, cheiros e músicas, também caminharam juntos conosco e, com isso, sempre fomos muito bem recebidos e co-respondidos. 


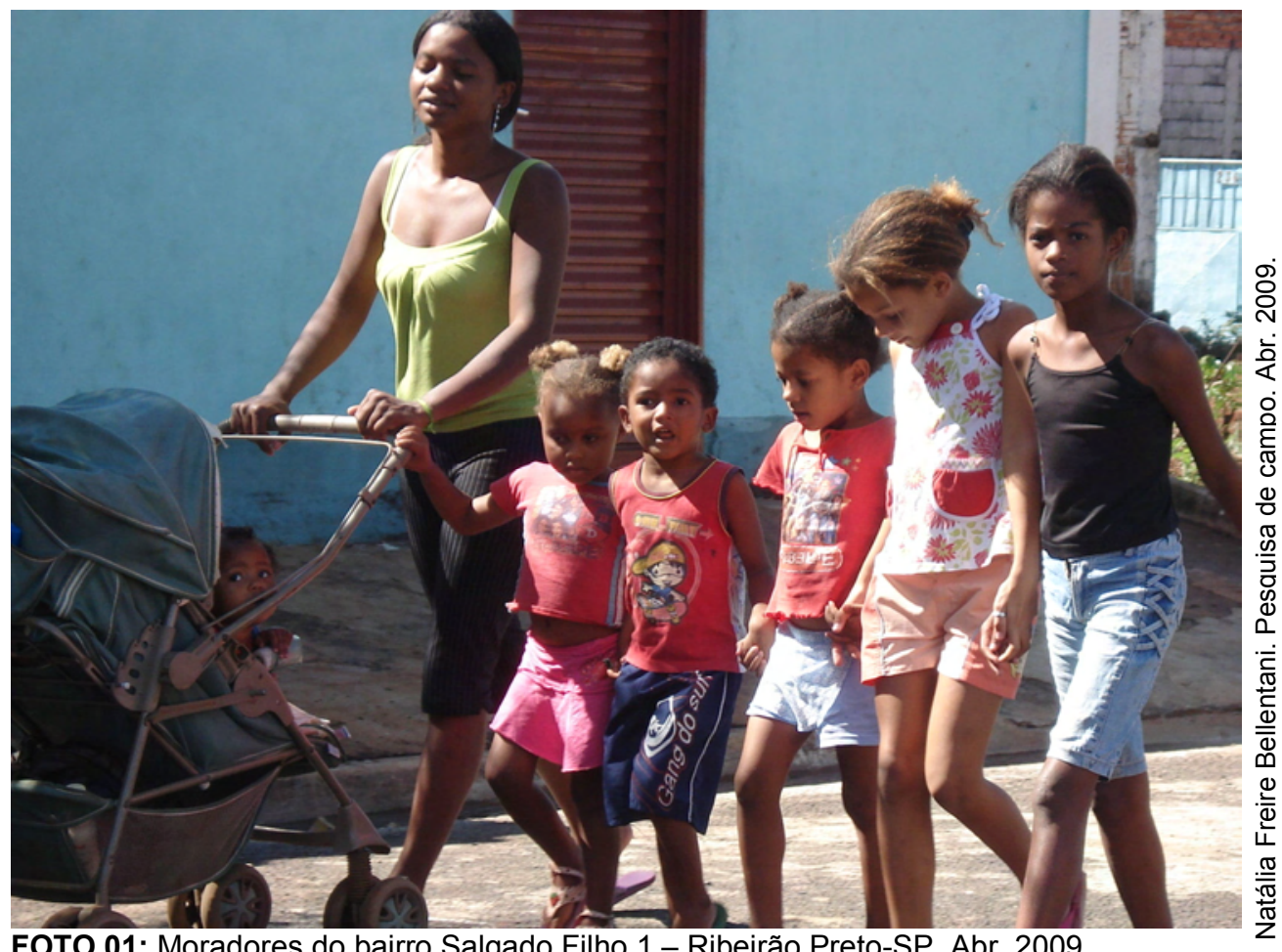

FOTO 01: Moradores do bairro Salgado Filho 1 - Ribeirão Preto-SP. Abr. 2009.

É fato que em alguns casos, especialmente, nos bairros da periferia, encontramos certa resistência dos sujeitos para responderem aos questionários, sendo que, durante a pesquisa, foi necessário considerarmos "o silêncio também como uma forma de dizer" (SILVA, 2007, "notas de aula"), uma vez que compreendemos que sobre "determinados assuntos" muitos não podem (devem) falar, como por exemplo, sobre segurança e a violência dos bairros - exploração sexual, abusos e violência doméstica.

No dia a dia, pelas ruas, algumas pessoas mais ansiosas apressam-se para esperar o ônibus (que vai demorar!), mas naquele momento estar à frente da fila pode representar a vitória de mais uma jornada que vai começar.

Nas esquinas, ou em pontos específicos das estradas de terra e, por vezes, beirando a rodovia, como é o caso do assentamento "Sepé Tiarajú", as crianças 
aglomeram-se (com seus uniformes de diferentes escolas, mas que acima de tudo, Ihes imprime uma identidade comum: estudantes) e seguem para a escola, junto às mães trabalhadoras de duplas ou triplas jornadas que revezam-se para levá-los ao ponto de ônibus e na maioria das vezes juntam-se a eles, nesse ir e vir, na tentativa de buscar emprego ou mesmo para ir trabalhar, na maioria dos casos, como domésticas ou diaristas.

Na periferia, em outras esquinas, nem tão longe dessas primeiras e nem tanto tempo depois do primeiro "sinal" das escolas tocar, onde também estudam as crianças dos assentamentos, a prostituição dá os primeiros sinais de que também mais um dia de trabalho vai começar e a ela está entremeado o tráfico de drogas, que não acaba de começar o seu dia, porque, esse sim, não parou para descansar.

Portanto, nesse conjunto de características em movimento compõem nosso recorte espacial, o modo de viver dos sujeitos revela-se e com isso permite-nos apreender diferentes variáveis sociais, mas ao mesmo tempo faz com que tenhamos clareza sobre a necessidade de avançarmos nessa discussão em uma perspectiva que, além disso, também nos permita compreender as relações marcadas pelo poder, que estão no lugar e também no território. E essas relações marcadas pelo poder determinam a resistência e/ou a submissão, a autonomia e/ou a heteronomia dos sujeitos, apontando desta maneira para a realidade que então revelará quais são os dados que buscamos e qual é, ou o que é, e o que vem a ser o desenvolvimento humano. 


\section{2. e) Análise quantitativa e qualitativa}

Desta forma, para lidar com as informações coletadas buscamos contemplar ambas as dimensões: quantitativa e qualitativa, tentando também não provocar qualquer tipo de prejuízo a leitura critica da realidade. Afinal, como Lukács (1979) nos chamou atenção, "sem a interação entre a dimensão econômica propriamente dita e a realidade extra-econômica no quadro da totalidade do ser social não esclareceriam-se questões teóricas fundamentais".

Logo, houve uma preocupação em não compreender-se como sujeito-objeto e sim ter clareza de um processo de pesquisa que buscava apreender as (re)ações dos sujeitos, todos os comentários acerca dos temas tratados eram registrados, os números referentes aos dados quantitativos eram anotados e com isso as contradições expostas pelo ambiente e pelos próprios sujeitos em suas declarações não eram perdidas.

Neste caso, do ponto de vista do trabalho, segundo Gadotti (2002), seria ingênuo pensar que a avaliação é apenas um processo técnico, trata-se também de uma questão política. Avaliar pode constituir um exercício autoritário do poder de julgar ou, ao contrário, pode constituir um processo ou um projeto em que o avaliador e o avaliando buscam e sofrem uma mudança qualitativa. Neste aspecto é difícil mensurar o quanto o pesquisador e o pesquisado se transformam mutuamente. Por sua vez, a Universidade ao se debruçar sobre tais realidades faz com que os sujeitos, com os quais se relaciona, se descubram como foco de atenção e, sua vida como motivação para a formação dos pesquisadores. Isso 
coloca, de certa forma, um questionamento e uma valorização do cotidiano desses sujeitos sociais, tanto quanto possa o pesquisador reconhecer tal importância.

Ao final de cada dia de trabalho, as entrevistas tinham seus dados quantitativos tabulados em uma planilha para maior facilidade de representação e verificação das relações entre eles. Enquanto que seus dados qualitativos foram ponderados, com a intenção de buscar maior consistência teórica a este campo de reflexão e, posteriormente, expor seus resultados.

\section{2. f) Devolutiva}

Tendo em vista a forte demanda pela socialização do conhecimento científico, deve-se pensar, a posteriori nas formas de devolutiva da pesquisa, principalmente, para as comunidades que compõem o trabalho. Seja por meio de reuniões com as famílias entrevistadas, apresentando e dialogando sobre os resultados, seja pela veiculação do trabalho na imprensa local. Trata-se de formas de atender essa demanda e tornar acessível à produção acadêmica nas mais diversas áreas do conhecimento. 


\section{CAPÍTULO 2}

\section{ASSENTAMENTOS RURAIS E PERIFERIA}

\subsection{Ribeirão Preto-SP.}

“... A descoberta da cidade é a de um labirinto do vivido eternamente renovável, onde o indivíduo que nele adentra não é um ser completamente perdido ou sem rumo. É alguém que lida com memória e sensação, experiência e bagagem intelectual, recolhendo os microestímulos da cidade que apresentam caminhos que se abrem e se fecham..." (MOLES, 1984)

Lefebvre (1974) declara que ao analisar-se o espaço urbano deve-se considerá-lo como produto, condição e meio do processo de reprodução das relações sociais. Neste sentido, de acordo com Carlos (1994), se de um lado o espaço é condição tanto da reprodução do capital quanto da vida humana, de outro ele é produto e nesse sentido trabalho materializado. Ao produzir suas condições de vida, a partir das relações capital-trabalho, a sociedade como um todo, produz o espaço e com ele um modo de vida, de pensar, de sentir.

Logo, Lefebvre (1974) infere que o espaço traduz um conjunto de diferenças, ou seja, é o lócus de coexistência da pluralidade e das simultaneidades de padrões, de maneiras de viver a vida urbana. Contudo, não descarta a idéia de que o espaço também é o lugar dos conflitos, onde a exploração subordina não apenas a classe operária como outras classes sociais.

Por conseqüência no atual período técnico-científico-informacional, ou seja, período histórico marcado por um espaço geográfico constituído por objetos e ações de forte conteúdo em técnica, ciência e informação (SANTOS, 2002), pode-se 
afirmar que Ribeirão Preto é constituída por um entrelaçamento das características que Ihe são próprias e da multiplicidade de ações que lhe são externas (ELIAS, 1996).

Localizado no Nordeste do estado de São Paulo, a $313 \mathrm{~km}$ da capital, o município de Ribeirão Preto possui uma área territorial, de acordo com o IBGE, de $650,37 \mathrm{Km}^{2}$, sua população, em 2008 , foi estimada em 558.136 habitantes, sendo que em 2000 , a população rural representava cerca de $0,42 \%$ da população total. 0 município tipicamente urbano tem suas principais atividades centradas no comércio e na prestação de serviços. No entanto, o dinamismo dessas atividades sofre grande influência das atividades produtivas desenvolvidas ao seu redor.

A Região Administrativa de Ribeirão Preto conta com 25 municípios (Mapa 1) e a maior parte da área agrícola da regional é utilizada para o cultivo de lavouras temporárias. Exemplo concreto se configura por meio do monocultivo da cana-deaçúcar, onde sua expansão sobre áreas tradicionalmente utilizadas com culturas perenes e anuais, café e pastagens fez com que, desde o Proálcool, implementado nos anos 1970, a mesma assumisse um patamar de extrema importância na apropriação de terras agrícolas na região (SOUZA, 2008). 


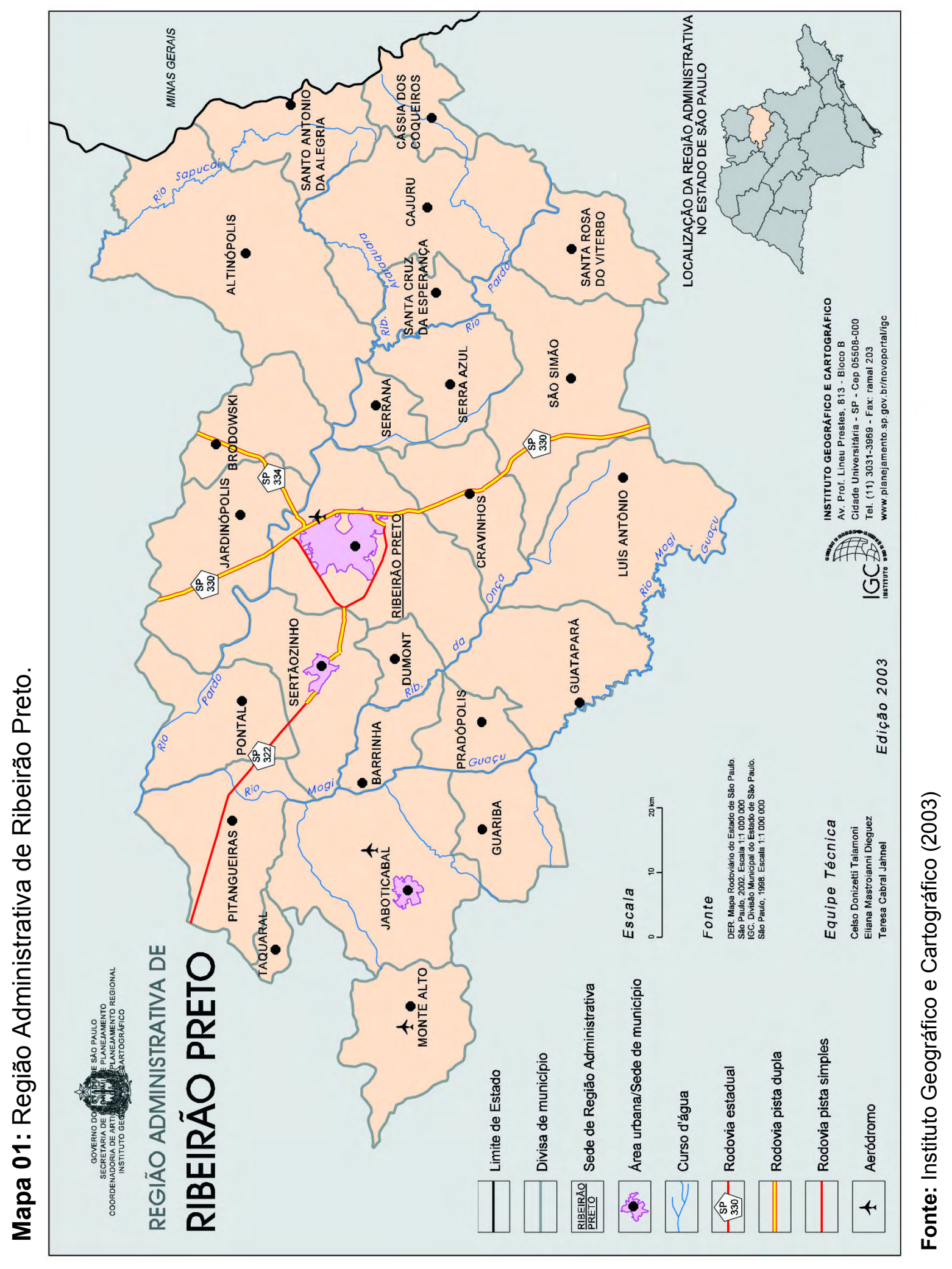


De acordo com Censo Agropecuário de 2006 (IBGE) a quantidade produzida de cana-de-açúcar (em toneladas) no município de Ribeirão Preto foi igual a 6.305.504, sendo o segundo maior produtor do estado de São Paulo, perdendo apenas para o município de Morro Agudo que produziu cerca de 7.248.703 toneladas, seguido por Jardinópolis com 5.576.428 t, Batatais 4.734.989 t e Pradópolis 4.326.977 t. Neste cenário certamente não há lugar para os trabalhadores, o capital controla completamente as propriedades e com isso a produção controla a circulação e não o contrário.

O município de Ribeirão Preto ficou conhecido na década de 1980 como "Califórnia Brasileira", o que promoveu a migração de enormes contingentes populacionais, alterando as relações sociais de trabalho e conseqüentemente, em função da constituição de um significativo "exército industrial de reserva", a fragilização das lutas e da organização sindical. Outro desdobramento desse processo foi o aumento populacional urbano, gerando violência e exclusão social.

Em períodos mais recentes esse processo ainda se mostra expansivo quando verifica-se que entre 2002 e 2007, a média de áreas incorporadas ao setor sucroalcooleiro, particularmente no Escritório de Desenvolvimento Rural/Secretaria de Agricultura e Abastecimento (SP) de Ribeirão Preto é de 27.000 hectares a cada ano (AGRIANUAL, 2007). Um processo que se intensifica com o Programa Nacional de Produção e Uso de Biodiesel (PNPB), implementado e legalizado a partir de 2005, ampliando o número de créditos ao setor e aproximando investidores internacionais; consolidando processo de desnacionalização produtiva, mas fundamentalmente impingindo rotinas e padrões técnico-produtivos aos trabalhadores (RAMOS, 2009). 
Segundo Bonato (2006) a determinação de padrões técnicos produtivos tem conduzido ao aumento do número de acidentes do trabalho no campo e nas estruturas de processamento agroindustrial, num total de 416 mortes de trabalhadores até o ano de 2005 (BONATO, 2006), sem contar os casos que não são notificados como acidentes de trabalho.

Neste sentido, o aspecto econômico no qual está focado esse modelo técnico produtivo, pautado em uma lógica limitante e fragmentada do conjunto de técnicas que compõem a sociedade atual, fortalecendo relações pragmáticas e o cientificismo, no controle produtivista da natureza e do trabalho humano. Revelando, portanto, uma perspectiva "assessória" que o trabalho vivo tem no processo de produção. A máquina e a velocidade determinam o processo produtivo, autômatos os trabalhadores se vinculam aos instrumentos, apêndices do que se processa como "lógica de desenvolvimento" que sintetiza-se intensamente em trabalho morto.

Não se trata de manter o trabalho do cortador de cana-de-açúcar nas atuais condições de penúria, abandono e escravidão (SILVA, 2006; SOUZA, 2007; ALVES, 2006) e sim de ressaltar a perspectiva tecnológica colocada para a sociedade atual, prevalecendo um extremo economicista que anula a qualidade de uma vida fecunda (ALEIXO; BELLENTANI, SOUZA, 2008), ou seja, para Luckács (1979) o econômico em detrimento do extra-econômico, no sentido de anulação de outras subjetividades.

Essa é a base do setor sucroalcooleiro no atual estágio de desenvolvimento capitalista no campo brasileiro, trazendo como fundamento um ideário liberal travestido de um discurso de modernidade que quer fazer valer as premissas de eficiência e competitividade. Neste processo, os setores conservadores buscam fazer crer que a truculência e o atraso no campo têm um lugar preciso no passado 
(SOUZA, 2007). Objetivam defender que o crescimento econômico se sustenta nas bases do dinamismo empreendedor, que seria capaz de gerar renda e empregos no campo. Transforma relações ditas arcaicas e velhas para este mesmo sistema, como modernas obscurecendo suas intensas formas de deterioração do trabalho, frente à baixa expectativa de vida dos trabalhadores, a precariedade das condições laborais dos mesmos - os quais recebem seus salários por produtividade. Sistema produtivo que impõe práticas, rotinas de trabalho que causam desde problemas respiratórios provocados pela queima da cana-de-açúcar, até a extenuação a biodiversidade, por meio da aniquilação de matas e rios, exaustão dos solos e conseqüente alteração climática, como mencionado anteriormente.

A "racionalização" progressiva da sociedade depende da institucionalização do progresso científico e técnico. Na medida em que a técnica e a ciência permeiam as esferas institucionais da sociedade e transformam assim as próprias instituições, desmoronam-se antigas legitimações. A secularização e o "desencantamento" das cosmovisões orientadoras da ação, da tradição cultural no seu conjunto, é o reverso de uma "racionalidade" crescente da ação social (HABERMAS, 1968).

Portanto, para a compreensão do sentido de tecnologia há uma face que não se revela. Prescinde-se do óbvio, ao estabelecer a primazia do trabalho morto frente ao trabalho vivo no processo de mecanização no campo. Nestes casos a produtividade, a produção, a quantificação do valor, corporifica-se e, anula-se o trabalho/trabalhador.

Para Menegat (2006) o homem se funde ao conceito de força produtiva justamente no momento em que ele é desnecessário como tal. Essa fusão tem o sentido de organizar a distribuição e o consumo nas mesmas formas de produção; 
nesses momentos, o valor de uso, bem como o trabalho concreto, são subsumidos pelo valor de troca e trabalho abstrato.

Segundo Marx (1988:116) se uma tecnologia está sendo inserida de forma inadequada, ela atua intensamente e sem contrapeso, no sentido de tornar excedentes os trabalhadores. Neste sentido, tanto a ideologia como a tecnologia, deverão inspirar-se na realidade do meio as engendram. No entanto, a ideologia imposta não se inspirou na realidade dos sujeitos, mostrando, desde logo, a sua inadequação para "tratamento" dos problemas sociais.

Não se pode discutir a questão da adequação tecnológica sem explicar o tipo de sociedade que se deseja construir. Pode-se observar que o problema fundamental não está no caráter científico do conhecimento em si, mas sim no seu aspecto político ideológico: a quem deverá servir a tecnologia a ser gerada? A escolha é essencialmente política, porque a decisão depende da relação de poder que a engendra e, no caso de uma economia capitalista, as regras de eficiência são as que maximizam os benefícios privados dos proprietários do capital (ALEIXO; BELLENTANI; SOUZA, 2008).

Atualmente boa parte do corte da cana-de-açúcar foi mecanizado, reduzindo ano a ano a necessidade de mão-de-obra. Para a região restou o déficit social e os impactos ao meio ambiente. O primeiro pelo desemprego crescente e a profunda exclusão, solidificando o problema da desigualdade social, o segundo, em função da perda das áreas de preservação e a poluição das nascentes e o comprometimento do Aqüífero Guarani.

De acordo com Freitas (2008:341) é inegável que o fenômeno da modernização agrícola (SILVA, 1999) constitui-se num fato contraditório. Se por um 
lado, logrou êxito à medida que possibilitou a acumulação e reprodução do capital e, por conseguinte, a ampliação das forças produtivas apoiadas pelas inovações de ordem técnico-científica, por outro lado, tal modernização contribuiu para as metamorfoses sócio-espaciais e o surgimento dos dilemas como a urbanização acelerada e aglomerada, a concentração da terra e um aprofundamento da exploração do trabalho pelo capital.

E com essa "modernização", advém a questão urbana, a poluição ambiental e a sujeição do trabalho ao capital, frutos irrefutáveis da ordem modernizadora. Observa-se assim a mediação que o trabalho encerra na relação homem e natureza em sua especificidade de produção, de valor, de tecnologia, uma mediação que elabora constructos ideológicos profundos de modernidade, "desenvolvimento" e um ideário de progresso do (a) capital do agronegócio. Uma singularidade do capital agrário que se cristaliza na diferenciação sócio-espacial rural/urbana de Ribeirão Preto-SP. 


\subsection{O campo: assentamentos rurais}

Trate bem a terra. Ela não foi doada a você pelos seus pais. Ela foi emprestada a você pelos seus filhos.

(Provérbio antigo do Quênia)

Longe de cumprir a função social da terra, prevista pela Constituição Brasileira (1988) que determina a desapropriação das propriedades que utilizam de forma inadequada os recursos naturais, que são improdutivas, degradam o ambiente ou impõem condições de trabalho escravo, o agronegócio transformado em ícone do Governo Lula, de acordo com Souza (2007), suplanta o atraso e a violência pelo empreendedorismo - com uma roupagem moderna de discurso da inclusão, da eficiência e da competitividade em que o uso da terra à exaustão passa a ser sinônimo de produtividade - [...] na perspectiva de certo crescimento econômico no campo brasileiro (SOUZA, 2007, p.3, grifo nosso).

Oliveira (2007) afirma que "o quadro recente da apropriação privada da terra no Brasil, mostra que menos de um terço é ocupada produtivamente", ou seja, que cumpriria sua função social, desconsiderando as condições sociais e ambientais desta exploração. O autor evidencia que "esta é a realidade sobre o uso da terra no Brasil, onde a maior parte delas não é ocupada de forma produtiva, mas, ao contrário, são terras improdutivas. E é desta forma que o capitalismo desenvolve-se no campo brasileiro, revelando seu caráter rentista" (OLIVEIRA, 2007).

Em vista disto, Carvalho (2005) diz que o objetivo estratégico de classe das classes dominantes é sempre o mesmo: a apropriação do espaço geográfico rural e a sua transformação em território do capital e dos especuladores de terras. 
No caso da expansão da plantação de cana, Carvalho (2008), afirma que "os impactos já são constatáveis na concentração da terra, na desagregação dos territórios camponeses, no aumento da exploração dos assalariados rurais, na contaminação e na degradação do meio ambiente; no aumento real da emissão de gás carbônico; na desnacionalização das empresas rurais e das agroindustrias; na afirmação da dependência da economia do país à exportação de commodities, além de afirmar um modelo econômico de concentração e centralização da renda e da riqueza no campo. A área plantada com cana está provocando uma reorganização do uso da terra agricultável no país, assim como exercendo forte pressão para o desmatamento dos biomas da floresta amazônica, mata atlântica, pantanal e cerrados. E, mais, irradia seu modelo de reprodução para diversos países da América Latina".

Sampaio (2003) avalia que nenhuma dessas conseqüências, econômica e socialmente indesejáveis, pode ser eliminada sem que o Estado intervenha diretamente na desconcentração da propriedade da terra, pois as relações econômicas, sociais, políticas e culturais que decorrem da estrutura agrária e condicionam o comportamento dos produtores e da população do campo são fortemente influenciadas pela forma como se distribui a propriedade da terra, e a forma como esta se distribui é o que determina a estrutura.

Nesse sentido, Carvalho (2005) observa que os denominados programas de reforma agrária do governo federal, neste passado recente da história do Brasil, tornaram-se, quando muito, políticas de caráter compensatório e populista. Segundo o autor, sequer foram implantados conforme o previsto ou, quando o foram, 
rapidamente se esvaíram pela pressão política em favor dos interesses das classes dominantes.

Ou seja, os fatos apontam para a insustentabilidade do país e longe das políticas paliativas, assistencialistas e/ou de responsabilidade social (como se convencionou chamar pelo sistema ora estabelecido) as mudanças nas atitudes da sociedade são urgentes. Principalmente no que diz respeito ao consumo, aos modelos de produção, ao grau de dependência nas relações intersetoriais, enfim aos fatores que compõe este processo de "modernização" imposto pela hegemonia do capital, os quais ocasionam a destruição da Terra.

Como destaca o Manifesto Ecossocialista (1991) a sobrevivência do planeta está colocada em risco, em função de uma sociedade que gera riqueza para poucos, miséria para muitos e degradação ambiental para todos.

Sampaio (2003) descreve que, enquanto os modelos econômicos forem voltados para a reprodução dos padrões de consumo do mundo desenvolvido, [...], com tudo o que ela significa em termos de miséria, opressão do povo da terra, crescimento insuficiente e sincopado da economia do país, deterioração do meio ambiente, dependência econômica e tecnológica.

De acordo com o autor, só será possível transformar essa terrível realidade com um modelo cujo objetivo central seja a satisfação das necessidades básicas de seus habitantes. Trata-se de organizar a economia com vistas a tornar mais homogêneo o padrão de vida da população, aumentar o grau de autonomia dos centros nacionais de decisão econômica, tornar a produção econômica compatível com o esforço de preservação do meio ambiente (SAMPAIO, 2003). 
Em vista disso, apesar do conceito de desenvolvimento sustentável fazer parte dos discursos ecológicos, Stahel (2001) salienta que nos mais diversos âmbitos de muitas nações, há que se questionar o consenso sobre tal conceito e sua aplicabilidade diante da conjuntura econômica, social e política contemporânea dos países, ou seja, se tal conceito tem algum sentido dentro do quadro institucional e econômico atual, o capitalismo.

O autor afirma que, este questionamento faz-se necessário, pois o desenvolvimento sustentável está atrelado, hoje, a um desenvolvimento capitalista "sustentável" e à sua lógica de mercado. No entanto, não se colocando a questão básica quanto à própria possibilidade de uma tal sustentabilidade, o conceito corre 0 risco de tornar-se um conceito vazio, servindo apenas para dar uma nova legitimidade para a expansão insustentável do capitalismo (STAHEL, 2001).

Sampaio (2003) confirma que a reforma agrária constitui um dos pilares para o desenvolvimento baseado nas características aqui apontadas como alternativas ao modelo vigente. Lembrando que, seus objetivos básicos são assegurar trabalho, renda, cultura e cidadania a toda a população do campo.

Logo, se reconhece que a construção de uma sociedade sustentável faz-se a partir de apontamentos que são gerados por movimentos sociais e políticos comprometidos com a produção e reprodução social, não por ficções geradas a partir de interesses limitantes deste tipo de desenvolvimento. Neste sentido, em uma perspectiva crítica, que inclui as relações contraditórias entre o campo e a cidade no espaço social "a conclusão é que a terra é mais do que terra".

Este símbolo, como destaca Balduíno (2004) se liga visceralmente à vida, é propriamente o lugar histórico dessas lutas, sucessoras das mais primitivas lutas dos 
índios, dos negros e dos camponeses que, na sofrida busca do próprio chão, foram descobrindo as outras dimensões do seu combate. "Terra é dignidade, é participação, é cidadania, é democracia”.

Portanto, destaca-se para esta trajetória de luta e resistência a formação dos assentamentos rurais, que redefinem em seu cotidiano as práticas sociais, fazendo enfrentamento ao modelo de produção hegemônico e assumindo o trabalho como categoria central para o desenvolvimento dos sujeitos.

\section{2. a) Assentamento Sepé Tiarajú}

"Quando eu era criança, esse manejo todo, que eu achava muito ruim pra capinar, já era agrofloresta. Só que não tinha esse nome. "Foi meu pai que me ensinou que numa pequena terra a gente pode colher muita variedade" (ASSENTADA, em entrevista ao REPÓRTER BRASIL em Novembro de 2007)

O assentamento "Sepé Tiarajú" é fruto de uma trajetória de ocupações realizadas pelo Movimento dos Trabalhadores Rurais Sem Terra - MST, na região de Ribeirão Preto, que se iniciou em 1999 no município de Matão, passando por Barretos até chegar à Fazenda Santa Clara (antiga Usina Nova União), que localizase entre os municípios de Serrana e Serra Azul.

Em 2000, a Fazenda Santa Clara foi ocupada inicialmente por 30 famílias, chegando a ter 100 famílias algumas semanas depois. Após duas tentativas de reintegração de posse, em agosto de 2003 a área de 797 ha foi comprada do governo do estado de São Paulo pelo Instituto Nacional de Colonização e Reforma Agrária (INCRA) e em 2004 saiu a Portaria n 46/INCRA que deu inicio ao processo de assentamento de 80 famílias no local (SCOPINHO, 2007, p. 9). (Mapa 02). 


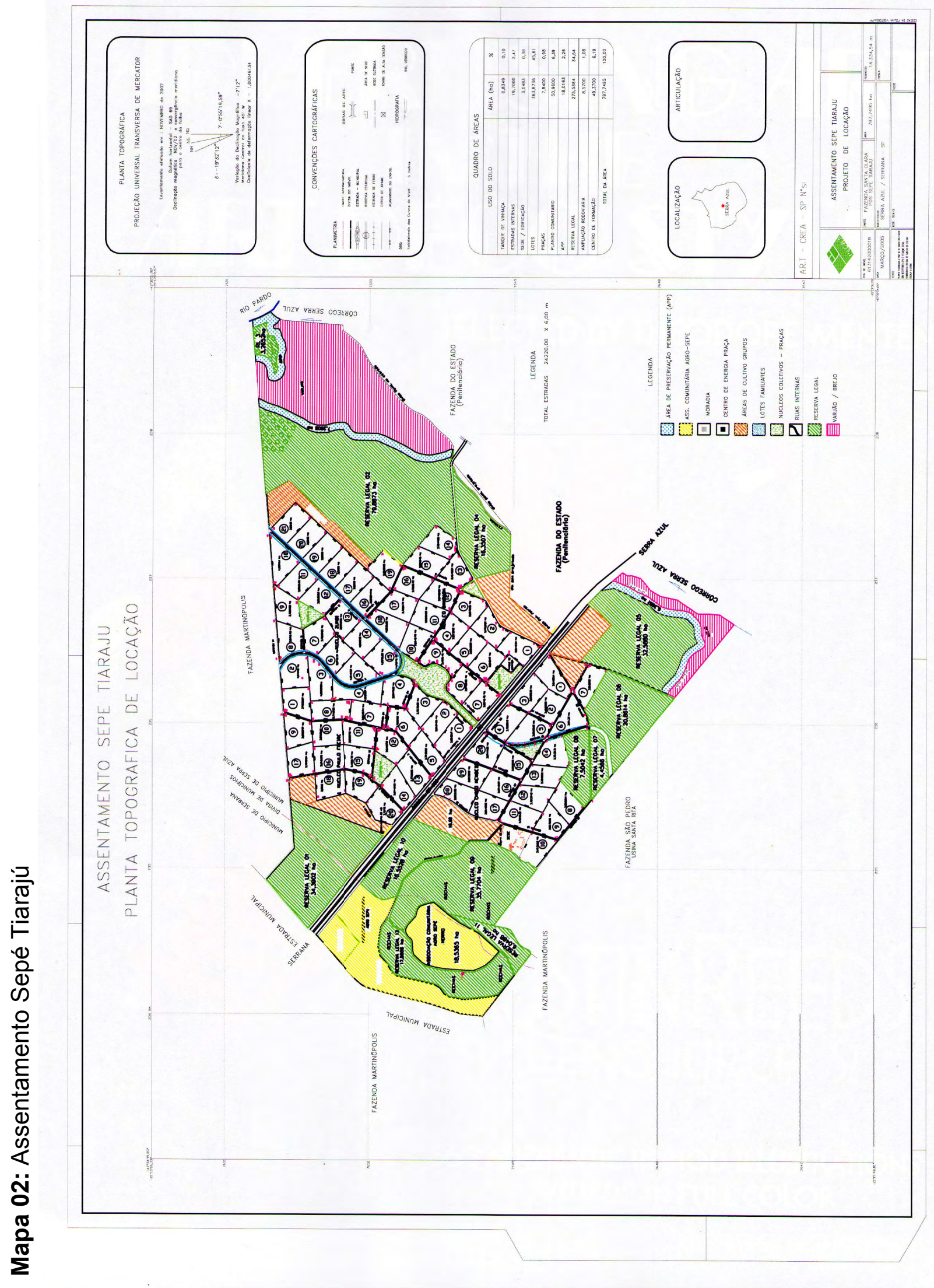

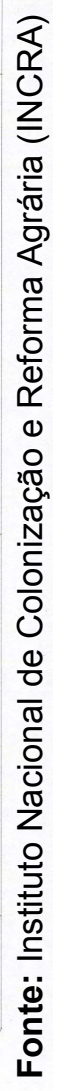


O respeito ao meio ambiente é o principal compromisso assumido pelos assentados do "Sepé Tiarajú" junto ao Ministério Público Estadual (MPE) de São Paulo, por meio de um Termo de Ajustamento de Conduta - TAC (MONTEIRO F. M., 2007). De acordo com a Agência Brasil (2007) esta foi a melhor saída para produzir naquela área de solo degradado pelo monocultivo da cana-de-açúcar. Como afirmam os assentados, desde o início o projeto de ocupação da área foi baseado na proposta da Comuna da Terra (CONCRAB, 2006).

Goldfarb (2007) sustenta que a Comuna da Terra é uma nova forma de assentamento rural idealizada pelo MST do estado de São Paulo, desde 2001, cujas principais características são: "serem constituídas por pessoas que viveram muitos anos em grandes centros urbanos como São Paulo, Campinas, ou Ribeirão Preto e que, portanto, não possuem um passado recente ligado à terra; serem implantadas em áreas bem próximas aos grandes centros urbanos; utilizarem a agroecologia e a cooperação como principais diretrizes na produção e; possuírem a Concessão Real de Uso da área no nome de um coletivo (associação ou cooperativa), e não individualmente, e nem o título de propriedade da terra, o que significa que as famílias não poderão, em nenhum momento, vender o que seria sua parcela" (GOLDFARB, 2007, p.11).

Para poder viabilizar a demanda por parte do MST em criar as comunas da terra, Goldfarb (2007) afirma que o INCRA de São Paulo utilizou-se do Projeto de Desenvolvimento Sustentável - PDS, uma modalidade de assentamento elaborado a partir das experiências das Reservas Extrativistas da Amazônia. "O PDS foi criado pelo INCRA por meio da portaria $n^{\circ} 477 / 1999$, para poder assentar pessoas que não constituem uma comunidade tradicional, em áreas relevantes para o meio ambiente, 
como remanescentes de mata atlântica, áreas da Amazônia ou do cerrado." De acordo com a autora, além de garantir a preservação de áreas ricas em vegetação nativa os Projetos de Desenvolvimento Sustentável também representam a possibilidade de recuperar áreas inseridas em regiões em que a biodiversidade de grandes extensões de terra foi sendo destruída pelo manejo predatório de monoculturas (GOLDFARB, 2007, p. 30-31).

Contudo, até hoje, poucos trabalhos expõem os prejuízos desse modelo de assentamento rural, especialmente no estado de São Paulo, de toda forma é possível apontar a fragilidade que existe em assentar cada família, como é o caso do assentamento "Sepé Tiarajú" em um área com menos de 3,5ha/lote aonde terão que viver, trabalhar e produzir (no assentamento "Mário Lago" são menos de 2ha/lote), ou seja, ainda que Ribeirão Preto possua um solo com alta fertilidade, condições de clima e relevo adequados para garantir uma produção de alimentos razoável, mesmo assim, esse modelo não assume os riscos de outras áreas que não possuam tais condições e com isso não conseguem produzir nem mesmo o alimento para o auto-consumo.

Vale a pena salientar a importância desta reflexão sobre a forma e com qual conteúdo os assentamentos no estado de São Paulo têm se desenvolvido. Não se trata apenas de assentar as famílias, mas sim de fazer a reforma agrária. Proposta esta que decididamente tanto o governo federal, quanto o próprio movimento social de luta pela terra precisam enfrentar, concomitantemente aos estudos e pesquisas realizados pela universidade. Evitando desta maneira, a realização de um projeto que esteja em oposição à efetiva política de reforma agrária, remetendo de certa forma a programas de interesse da classe dominante que caracterizam-se pelo 
controle social, como, por exemplo, o programa "Vilas Rurais", criado em 1995 pelo governador do Estado do Paraná, Jaime Lerner.

Faz-se fundamental, com já dissemos anteriormente, questionarmos que tipo de reforma queremos, para que esse tipo de programa (propagandeado como reforma agrária) não se reproduza com novos nomes mas com as mesmas expectativas e conteúdos paliativos que atendem especialmente àqueles que controlam os meios de produção.

Contudo, vale destacar que devido às qualidades que são inerentes a região de Ribeirão Preto (incluindo a área onde está localizado o assentamento "Sepé Tiarajú") e ao trabalho das famílias assentadas, hoje, no assentamento, o que pode ser visto é uma multiplicidade de lavouras e criações de pequenos animais, em um sistema agroecológico, que transforma a paisagem, contrapondo-se à homogeneidade do verde provocado pelo monocultivo da cana-de-açúcar (Foto 02).

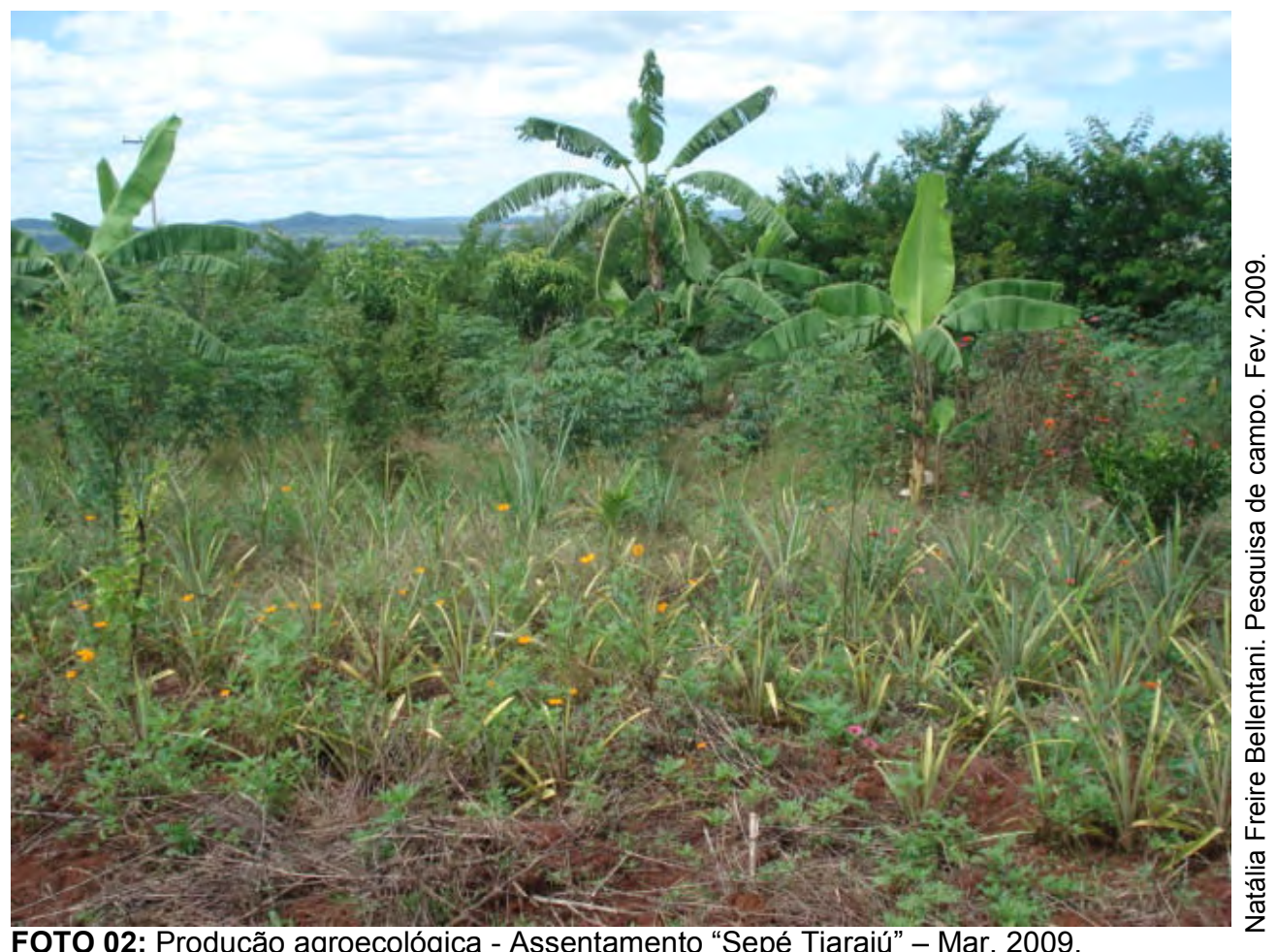

FOTO 02: Produção agroecológica - Assentamento "Sepé Tiarajú" - Mar. 2009. 
Vasquez (2009:168) revela que segundo dados do IBGE, 98\% da área agrícola de Ribeirão Preto é destinada ao plantio de cana-de-açúcar e que a região onde está localizado o assentamento se caracteriza pela monocultura de cana, para beneficiamento nas várias usinas da região, com o fim de produzir álcool.

Também, destaca-se que no que tange a infra-estrutura (água, luz, estradas, escolas, posto de saúde, etc), assistência técnica (engenheiros agrônomos, zootecnistas, veterinários e técnicos agrícola) e organização (associações, cooperativas e movimentos sociais) do assentamento há muito que ser feito e discutido para que as famílias consigam caminhar de forma completamente autônoma, no sentido efetivo da possibilidade de transformação social.

Por conseqüência, entendemos que não basta a implantação de assentamentos rurais sem que as necessidades básicas dos trabalhadores sejam atendidas, afinal uma política efetiva de reforma agrária deve promover a cidadania e concretizá-la por meio da ações transformadoras desse sujeitos históricos.

\section{2 b) Assentamento Mário Lago}

"Tudo começou em 2 de agosto de 2003, quando ocupamos um sítio perto da fazenda. Desde então moro num barraco coberto por plástico, mas não me arrependo. Hoje crio porcos e galinhas, vendo leitões e ovos, planto milho, quiabo e abóbora, e vivo da terra. E agora uma parte dela vai ser da minha família" (ASSENTADA, em entrevista ao Jornal A CIDADE, em Maio de 2007).

O Movimento dos Trabalhadores Rurais Sem Terra (MST) desenvolveu e ampliou as formas de luta nas áreas de dominação do agronegócio em Ribeirão Preto - SP. Esse processo de ocupação e resistência também se sucedeu na (antiga) Fazenda da Barra e promoveu a conquista de mais uma área que não cumpria sua função social. 
O INCRA em São Paulo recebeu em agosto de 2006 a posse da Fazenda da Barra, em Ribeirão Preto, conforme decisão judicial. A área tem 1.790,80 hectares e está ocupada pelas famílias sem terra, desde 2003 (MDA, 2006). A Fazenda da Barra, de acordo com o INCRA, foi decretada para fins de reforma agrária em dezembro de 2004, sendo classificada como grande propriedade improdutiva. Todavia, como indicou o INCRA, dois recursos e um pedido de liminar que foram atendidas geraram a suspensão do processo. Em maio de 2007, o Tribunal Regional Federal da $3^{a}$ Região concedeu a imissão de posse da Fazenda da Barra ao INCRA, mediante muita luta e resistência por parte dos movimentos sociais de luta pela terra.

Conforme aponta o Ministério do Desenvolvimento Agrário - MDA, este assentamento é o décimo PDS do estado de São Paulo, seguiram o modelo do Assentamento Sepé Tiarajú. De acordo com o MDA, o PDS garante o manejo ecológico e sustentável da terra, sendo esta uma alternativa ao modelo tradicional de agricultura, por meio de uma série de estratégias produtivas e organizativas que levam em conta a recuperação do meio ambiente (MDA, 2006).

Considerando ainda que o Assentamento "Mário Lago" localiza-se na área de recarga e afloramento do Aqüífero Guarani e a produção ecologicamente responsável desenvolvida pelos assentados, permite a sua preservação. Além disso, o projeto de assentamento aprovado entre os membros do MST, também baseado na "Comuna da Terra", prevê dentre outras coisas a posse coletiva da terra, inviabilizando desta maneira a prática do arrendamento, bem como que $35 \%$ da área seja reservada para matas (reserva legal) e que a produção agrícola seja $100 \%$ ecológica. 
Eventos que já se estabelecem no cotidiano de 424 famílias cadastradas que estão assentadas na área. Vale ressaltar que nesta área de reforma agrária de Ribeirão Preto, encontram-se dois movimentos de luta pela terra, quais sejam: Movimento dos Trabalhadores Rurais Sem Terra - MST (264 famílias); Movimento de Libertação dos Sem Terra - MLST (116 famílias); e uma associação independente de trabalhadores rurais, intitulada "Índio Galdino" (44 famílias). (Mapa 03). 


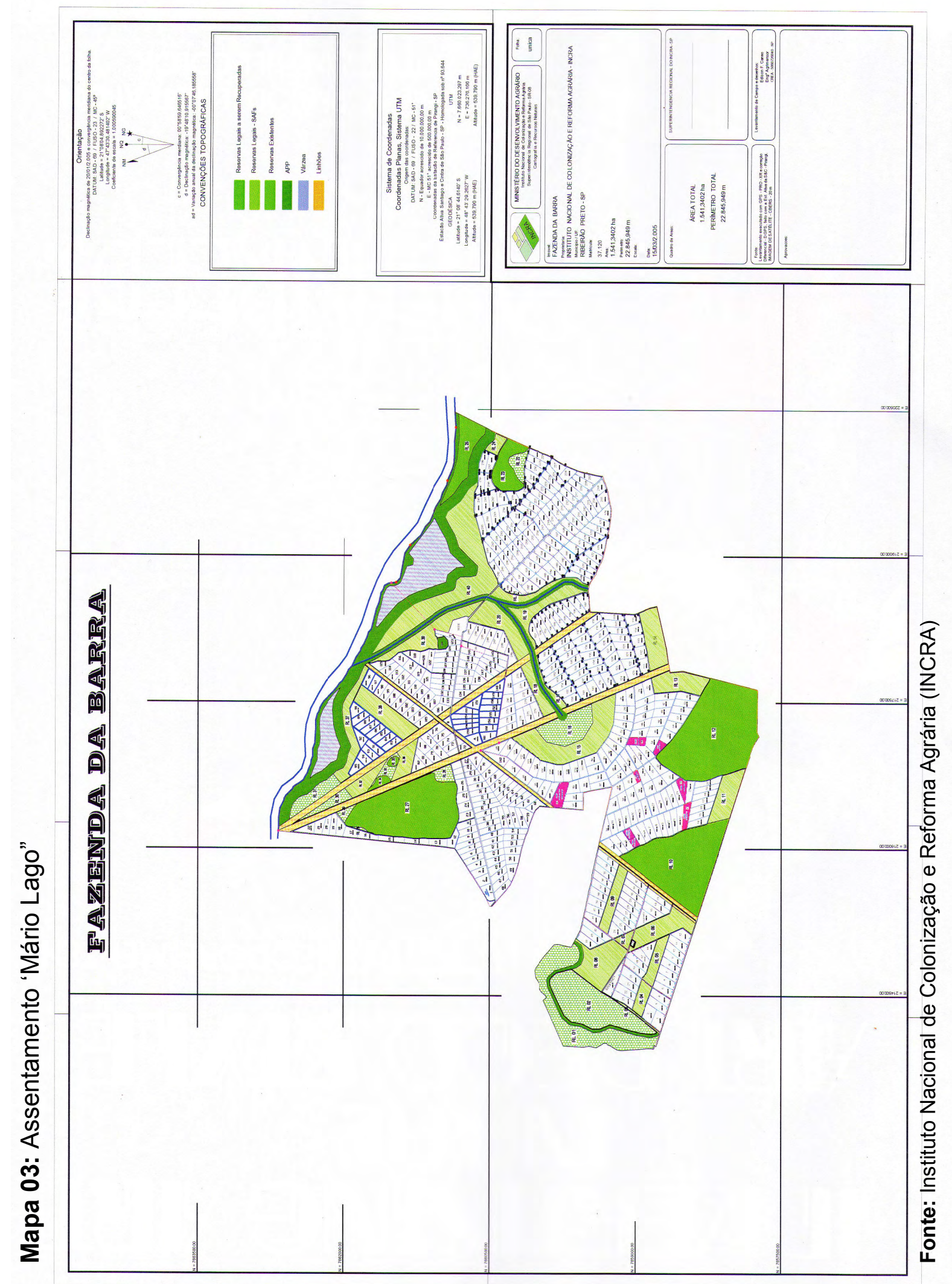


Essa configuração institucional não determina apenas diferenças perceptíveis no que tange à organização das famílias, mas também no acesso à infra-estrutura e à assistência técnica, já que as famílias que são do MLST, por exemplo, se beneficiam de forma irregular do sistema de água e energia elétrica por estarem mais próximas à cidade, enquanto que as tantas outras famílias organizadas pelo MST que estão assentadas em outra parte da antiga fazenda da Barra, mais afastadas dos bairros urbanos, deixam de captar água, tendo que esperar o serviço que vem da Prefeitura, em um caminhão pipa, para encher as caixas d'águas ou tonéis a cada 15 dias em média. No que tange à assistência técnica, as famílias que estão mais organizadas recebem os técnicos em suas reuniões e discutem coletivamente, solucionando ou não os problemas, já àquelas que estão mais isoladas normalmente demoram mais a receber o auxílio dos técnicos para encaminhar a produção.

Os conflitos são iminentes entre os distintos movimentos que estão organizados dentro do assentamento, visto que possuem divergências políticas e também organizativas. Mas, mesmo assim, todas as demandas por melhores condições, são urgentes a todos, indistintamente, visto que a morosidade na resolução de problemas concretos da área é determinante para a permanência dos sujeitos na terra.

Mesmo que com inúmeras dificuldades enfrentadas no dia-a-dia dos trabalhadores (incluindo a opção feita pelo modelo de assentamento "comuna da terra" que hoje mantém as famílias com menos de 2 ha para produzirem), este assentamento consolidou-se como um grande produtor de alimentos orgânicos, considerando que em Ribeirão Preto não há produção de alimentos que seja 
significativa. Assim, paulatinamente reconstrói-se a biodiversidade em um município devastado pela monocultura da cana-de-açúcar. Além disso, devolve-se aos sujeitos perspectiva de vida futura, pautados especialmente pelo rompimento com os grandes grupos empresariais do setor sucro-alcooleiro que controlam quase que completamente as propriedades dessa região.

Contrário à negligência do setor sucro-alcooleiro quanto ao cuidado e preservação do meio ambiente, no ano de 2009, representantes do assentamento discutiram com o Ministério Público um Termo de Ajustamento de Conduta - TAC para a área destinada à reforma agrária, procurando desta forma consolidar um processo de ocupação pautado em uma lógica promotora de um desenvolvimento de fato sustentável, comprometida com uma agropecuária ecológica.

A diversidade na produção ecológica revela também a multiplicidade da origem das famílias que vivem hoje no assentamento "Mário Lago". Muitos são migrantes, de todas as regiões do Brasil, especialmente norte, nordeste, mas também sul e sudeste. A migração é uma marca das áreas de assentamento estudadas ("Sepé Tiarajú e "Mário Lago"). Miscigenações, comportamentos e sotaques que não são semelhantes se multiplicam pelo assentamento. Os hábitos, e a socialização dos distintos conhecimentos, manifestam-se por toda a área e explicita uma relação de aprendizado entre as famílias (Foto 03). 


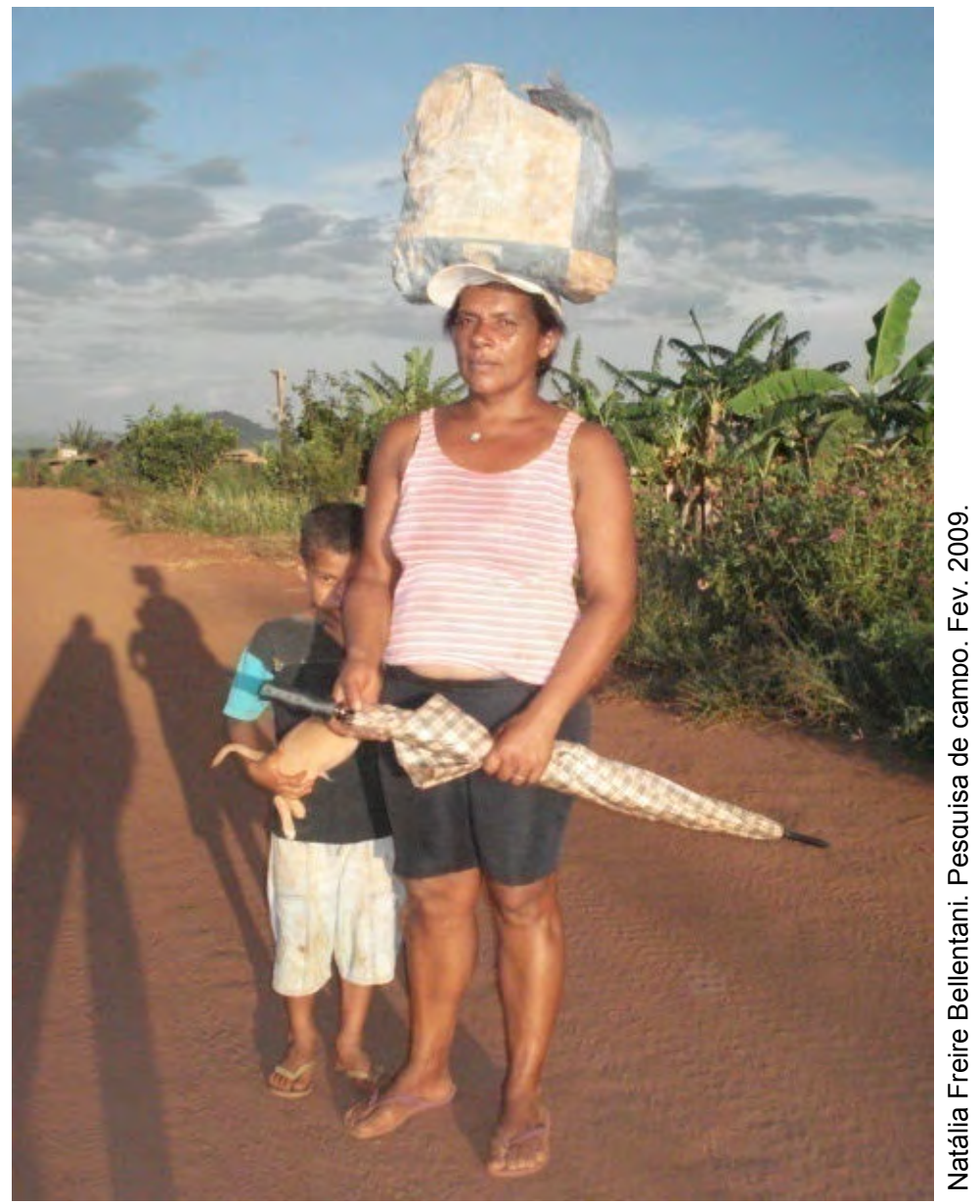

FOTO 03: Cotidiano no Assentamento "Mário Lago" - Fev. 2009.

Ainda que as origens sejam muitas vezes divergentes, as histórias de vida se repetem e pudemos observar que tanto no assentamento "Mário Lago" como no assentamento "Sepé Tiarajú" $100 \%$ dos entrevistados se definem como sendo "do campo", nenhum deles disse sentir-se como "da cidade" e justificam em suas declarações: "estou aqui todo dia, sou do campo mesmo e não tenho vergonha de dizer não"; "sou nascido(a) e criado(a) na roça"; "eu sou esse sossego do campo"; "nem me lembro da cidade"; "adoro a natureza e as coisas do campo, por isso me sinto daqui"; "cidade só da gasto, quero nem ouvir falar"; "sou do campo, mas tenho a linguagem da cidade"; "sou do campo e quero dar para os meus filhos aquilo que tive"; "quando tenho que ir à cidade, vou obrigada, a cidade dói a cabeça". 
E na periferia $95,72 \%$ dos entrevistados se definem como "da cidade" e justificaram-se dizendo, por exemplo, que: "me sinto assim, da cidade, pois é o único modo de viver que conheço". Aqueles que, na cidade, se dizem do campo, $4,28 \%$, responderam, entre outras coisas que: "estou na cidade, vivo esta realidade, mas me sinto do campo, já que fui nascido e criado na roça"; outros entrevistados além de se justificarem com o mesmo argumento ainda consideraram a possibilidade de um dia terem um pedaço de terra para trabalhar, afinal, como falou uma das entrevistadas do bairro Jardim Salgado Filho 1: "quero proporcionar aos meus filhos aquela fartura que tínhamos lá na roça”.

É importante lembrar que, nos bairros de periferia das cidades, as famílias sobrevivem próximas à marginalidade social e as trajetórias de luta e resistência dos assentados também passa por esse enfrentamento e com isso reforça a unidade de classe dos trabalhadores, no campo e na cidade. 


\subsection{A cidade: periferia}

“... a reprodução ampliada do capital também é

a reprodução ampliada das contradições sociais..."

(LEFEBVRE, 1974)

Em Spósito (2004:115) lê-se que "a urbanização brasileira contemporânea foi, marcadamente, influenciada pelas transformações econômicas, políticas, sociais e espaciais propiciadas pela intensificação e mudança nas formas de articulação do Brasil com a economia capitalista".

Ideais como liberdade, igualdade, tolerância e respeito à diferença, na ótica de Augusto (2002), são progressivamente substituídos pela fragmentação e pela separação rígida de espaços (também sociais), garantidas por uma segurança sofisticada e estruturada sobre a valorização da desigualdade. Em contrapartida, a autora assegura que "vem à tona o desrespeito à justiça e aos direitos individuais, impedindo a expansão da democracia para além das possibilidades conferidas pela participação política".

Martins (2008) afirma que é na periferia que se confirma o domínio da renda da terra na cidade. O autor considera que "a periferia é a designação dos espaços caracterizados pela urbanização patológica, pela negação do propriamente urbano e de um modo de habitar e viver urbanos".

Quando Sanchez (2006) assevera que o conceito de periferia urbana deve ser entendido de maneira mais ampla a autora se refere a uma restrição normalmente dada ao conceito e que diz respeito especialmente a dimensão "geográfica" e social, deixando de apresentar, por exemplo, uma dimensão simbólica (imaginário, representações sociais, discursos, etc.). Sanchez (2006) sugere que, para além das 
condições reais de existência (associadas às dimensões econômica, social e cultural), há também um aspecto fundamental em jogo na compreensão das áreas periféricas: "o tipo de representação construída em torno destes, e o modo como são representados na esfera pública, principalmente por meio da mídia”.

Nesse sentido, Anjos e Chaveiro (2007) ressaltam que as análises da periferia urbana englobam hoje novas modalidades como estudos da percepção, da representação, do cotidiano, do imaginário, da imagem, de narrativas. Essas modalidades partem de um pressuposto: o real é produzido também pelo modo de estabelecimento de significados. Ao fazer isso, de acordo com os autores, sujeito e objeto se aglutinam e no processo de significação o espaço se liga à vida.

Logo, Santos (2002) considera que, as grandes cidades do nosso tempo são também o lugar aonde a ética da competição e a pressão pelo status mais depressa conduzem ao individualismo aberto e possessivo, ao mesmo tempo em que a massificação termina por levar à fragmentação e à perda da individualidade. Morosidade, mau humor, hostilidades dissimuladas ou ostensivas, desordens psicológicas, violências, crimes são sintomas diversos de uma mesma síndrome e se encontram num mesmo lugar social, que é o medo. Há medos urbanos de toda natureza: objetivos e subjetivos, individuais e coletivos, ocasionais e permanentes, medos fundados e infundados. Eles habitam o cotidiano dos cidadãos e o envolvem num drama. A cidade do medo termina por criar todos os dias novos medos (SANTOS, 2002).

Assim sendo, Anjos e Chaveiro (2007:185) chamam atenção "em muitos casos, cria-se uma imagem pejorativa de determinados locais periféricos, identificando-os como dispersores da violência, sem que se compreendam os 
motivos que levaram tais sujeitos a esses lugares e a essas práticas e também sem a compreensão das outras faces dessa mesma periferia".

A área de periferia estudada nesta pesquisa refere-se a dois setores censitários (537 e 540) que compõem o sub-setor Norte 13, definição dada pelo Instituto Brasileiro de Geografia e Estatística (IBGE) em Ribeirão Preto. (Mapas 04 e 05). 
Mapa 04: Área periférica urbana do município de Ribeirão Preto - setor 537

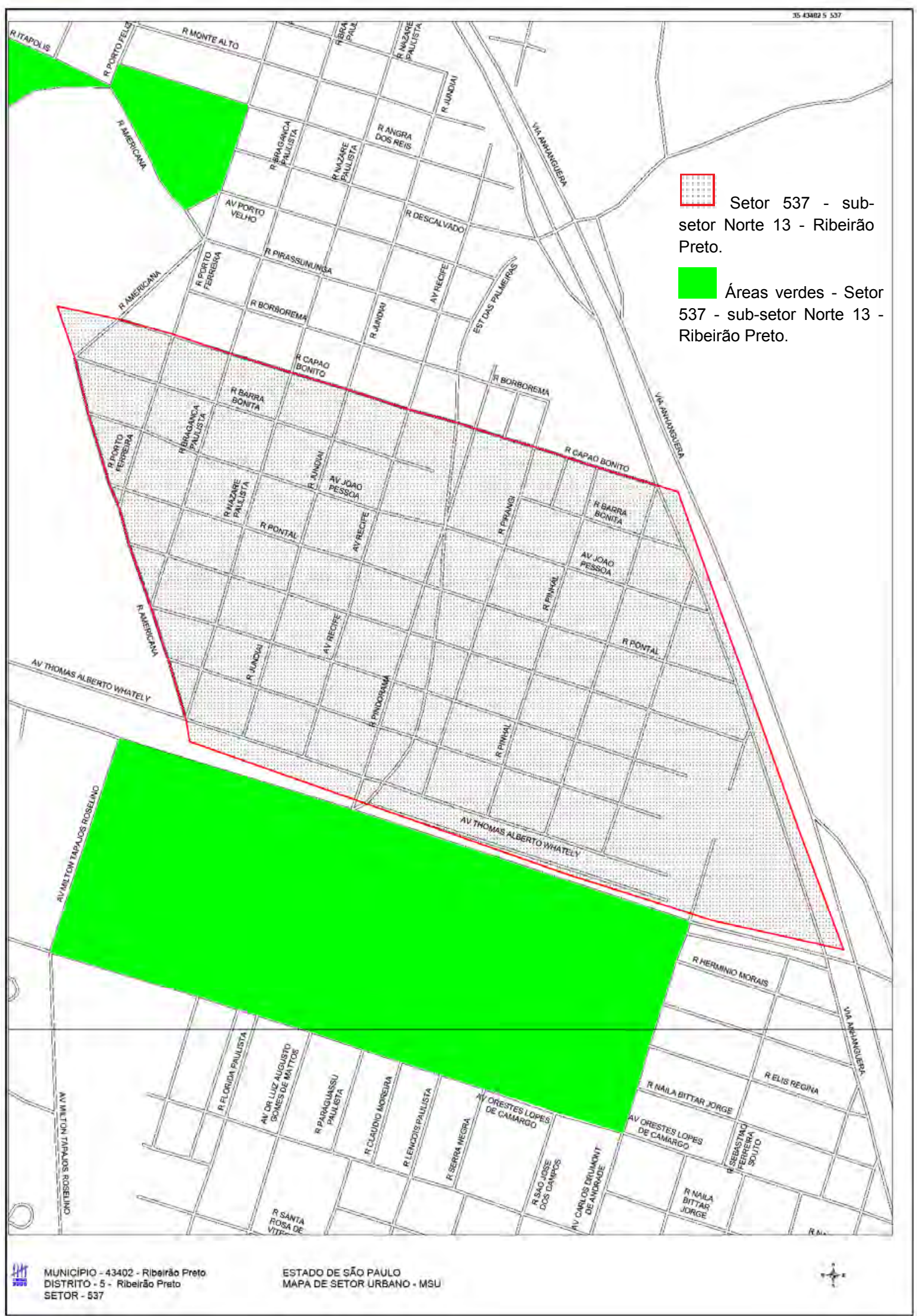

Fonte: Instituto Brasileiro de Geografia e Estatística - IBGE/Ribeirão Preto 
Mapa 05: Área periférica urbana do município de Ribeirão Preto - setor 540

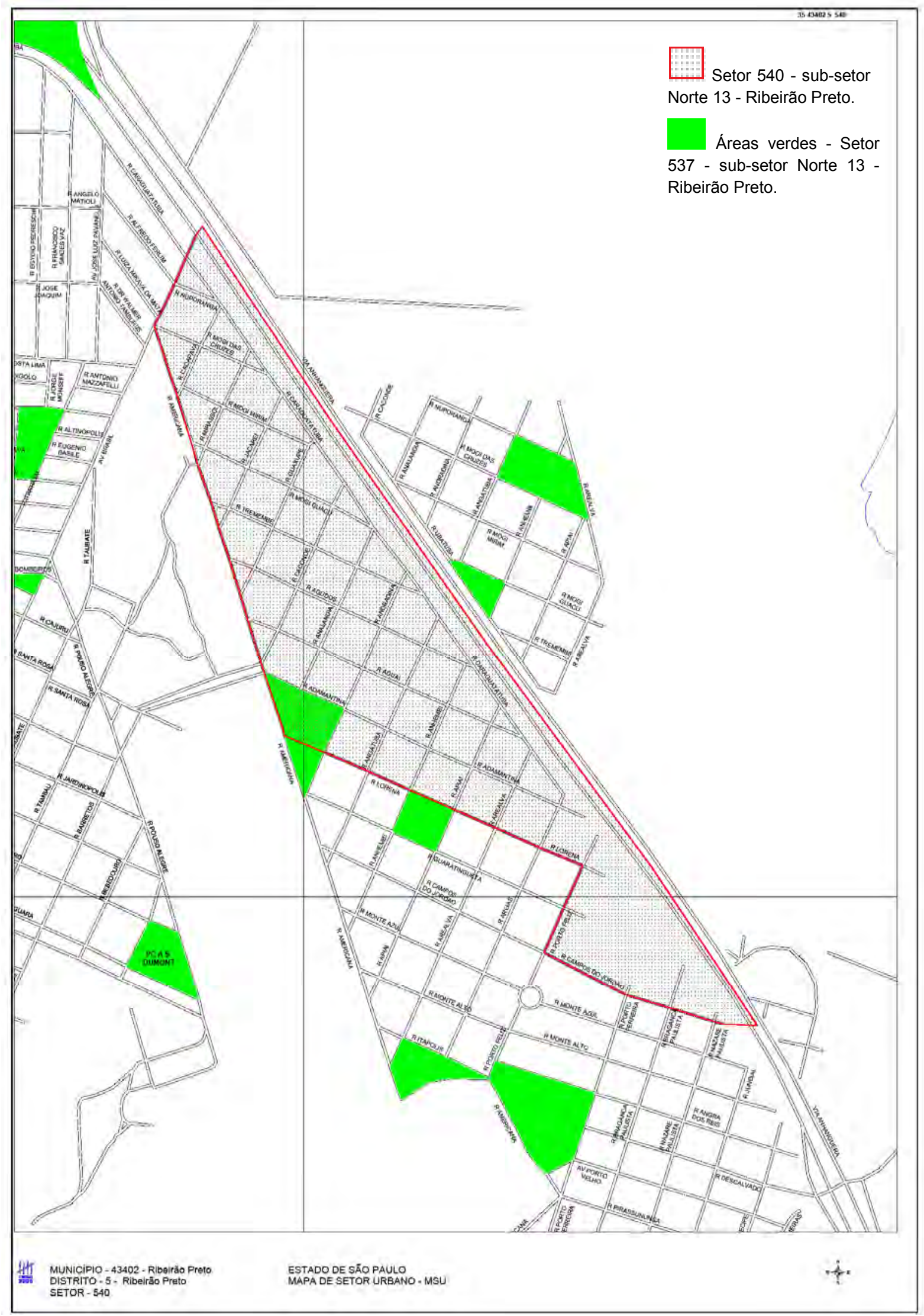

Fonte: Instituto Brasileiro de Geografia e Estatística - IBGE/Ribeirão Preto 
Esses setores recortam parte dos bairros Jardim Aeroporto e Jardim Salgado Filho 1. Bairros estes que, de acordo com o Arquivo Público e Histórico de Ribeirão Preto (2009), foram loteados na década de 1950, e estão situados nas proximidades do Aeroporto "Leite Lopes" de Ribeirão Preto.

Como expõem os arquivos, quando a Prefeitura do Município de Ribeirão Preto realizou o levantamento das terras para o projeto do bairro Jardim Aeroporto, os terrenos compreendiam uma gleba na Fazenda Palmeiras, confrontando de um lado com a estrada das Palmeiras, de outro com terras de Ruben Aloísio Moreira e outros, de outro com terras de Pascoal Gelfuso, e de outro lado com terras de Ademar Fornari. Isto significa dizer que, estes bairros estão localizados aonde os primeiros moradores da então Vila de Sebastião se instalaram, ou seja, de acordo com Lages (2009) a primeira fazenda de Ribeirão Preto foi a Fazenda das Palmeiras, local em que hoje se localiza o bairro Jardim Aeroporto.

Este conjunto de informações revela que a gênese do núcleo urbano Ribeirão Preto está dada em um local que atualmente é diametralmente oposto àquilo que se veicula como benesses da "capital brasileira do agronegócio" e, longe dos sofismas deste modelo de reprodução do capital, o que se vê nas áreas estudadas é uma persistente patologia, ora ligada ao medo, ora ao preconceito sofrido por famílias de trabalhadores que convivem cotidianamente com o tráfico de drogas que se espalha pelos bairros, associado a violência e também a prostituição.

O setor 540 compreende a 383 domicílios enquanto que o setor 537 reúne 315. As demandas por infra-estrutura, equipamentos públicos sociais e mais segurança são uma constante na rotina da população (Fotos 04 e 05). 


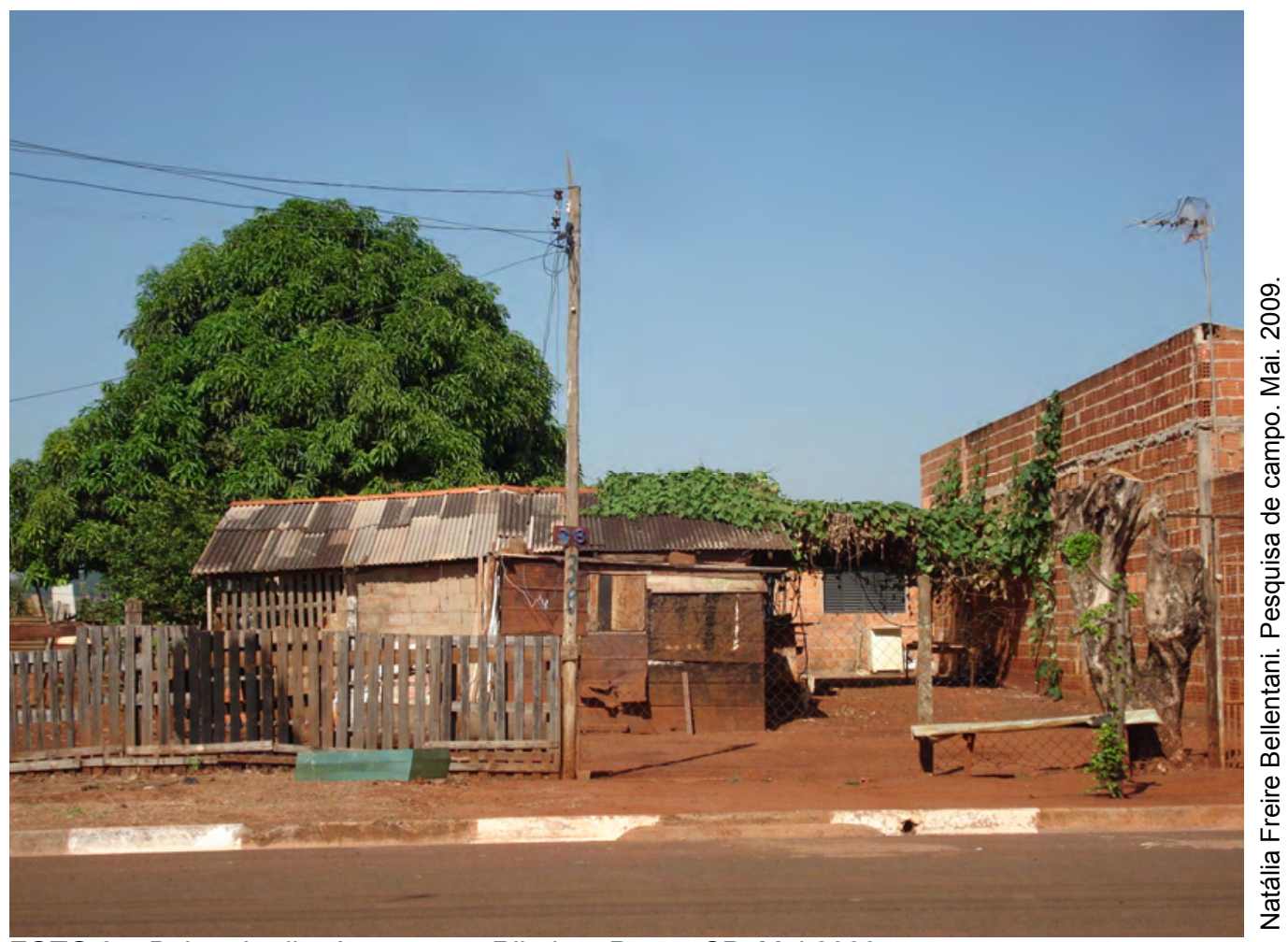

FOTO 04: Bairro Jardim Aeroporto - Ribeirão Preto -SP. Mai.2009.

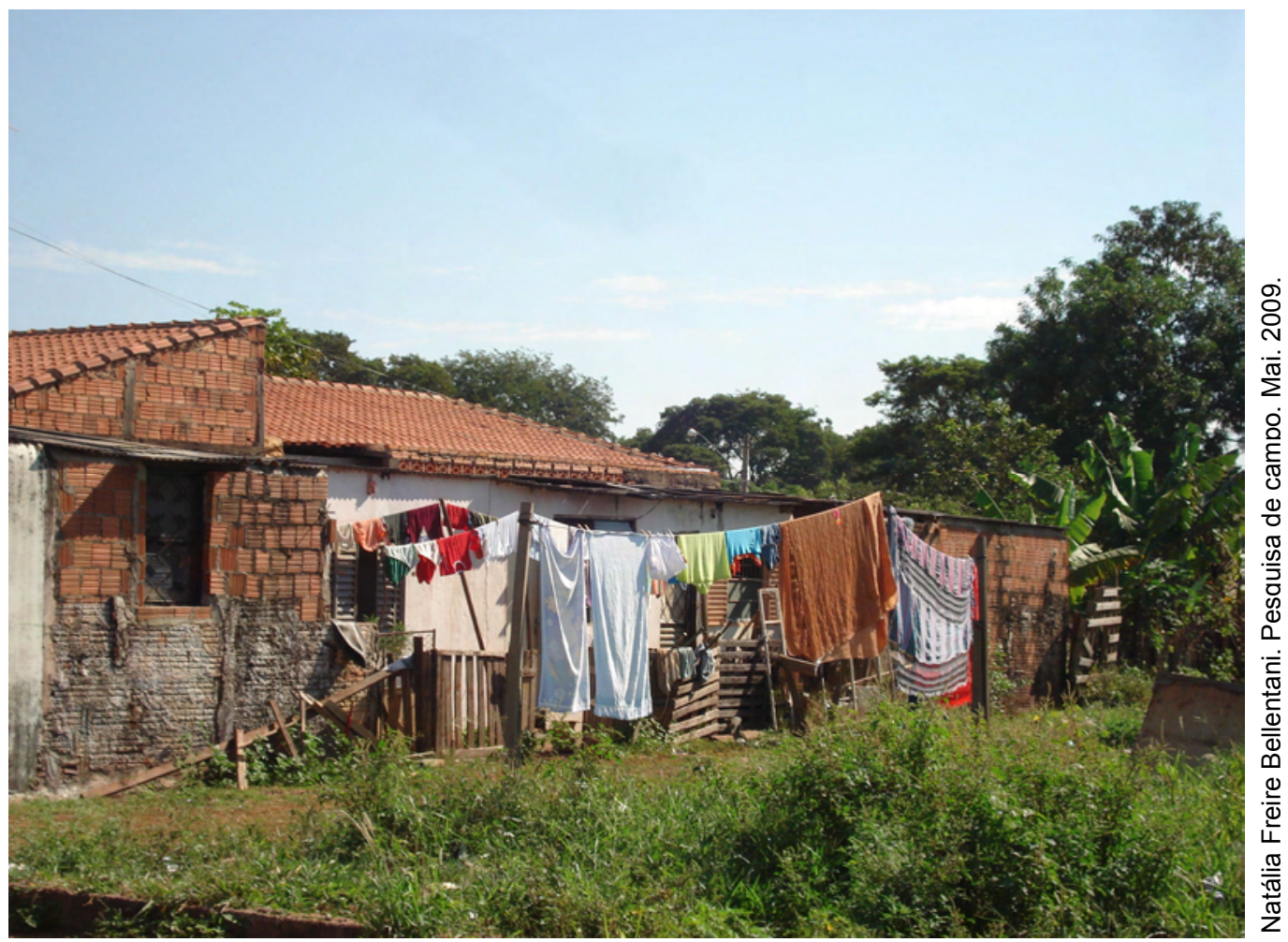

FOTO 05: Bairro Salgado Filho 1 - Ribeirão Preto -SP. Mai.2009. 
No interior desses setores existem algumas áreas de favelização, conforme indica o Relatório do Processo Investigativo da Favela da Mata e Itápolis, publicado em 2005. Nesses casos a grande preocupação da população no momento, é a ampliação do Aeroporto "Leite Lopes", pois segundo notas oficiais algumas propriedades, assim como alguns barracos serão desocupados para atender as determinações do EIA/RIMA - Estudo e Impacto Ambiental/ Relatório de Impacto sobre o Meio Ambiente. Vale ressaltar que a favela da Mata e Itápolis estão localizadas próximo ao aeroporto, uma área considerada de ruídos intensos segundo técnicos. Este mesmo relatório demonstra o crescente empobrecimento da população e desmistifica que nas favelas do município o maior número de moradores decorrem do processo migratório.

Por fim, salientamos que mesmo com todas as "lutas" e as várias manifestações, que aconteceram nos últimos anos, as famílias que residem nesses setores não apresentam qualquer tipo de articulação institucional que organize esse movimento contrário à marginalidade social em que vivem. E, normalmente esperam do poder público, ações que possam promover algum de transformação da realidade. 


\section{CAPÍTULO 3}

\section{DESENVOLVIMENTO HUMANO: UM SABER MÚLTIPLO.}

A redescoberta do desenvolvimento humano não é uma novidade. A ideia de que os arranjos sociais precisam ser avaliados pela sua eficácia em promover o "bem humano" remonta pelo menos a Aristóteles (384-322. a.C.). Ele argumentava que a "riqueza não é, evidentemente, o bem que procuramos, pois é meramente útil e existe em função de algo mais." Ele distinguia um arranjo político bom de um ruim pelos seus sucessos e fracassos em possibilitar ao povo gozar de uma "vida próspera" (HAQ, 2008, p.1).

Para Sen (2000) o desenvolvimento requer que se removam as principais fontes de privação de liberdade: pobreza e tirania, carência de oportunidades econômicas e destituição social sistemática, negligência dos serviços públicos e intolerância ou interferência excessiva dos Estados repressivos.

Essa constatação revela que o desenvolvimento humano provém de uma ação pública deliberada e efetiva, que possibilita às pessoas participarem no processo de desenvolvimento e dele beneficiar-se, desenvolver suas capacidades individuais e dar-Ihes um uso mais criativo e produtivo possível (PNUD, 2005).

De acordo com Salas (2005), a qualidade de vida não pode ser avaliada diretamente. A natureza abstrata desse objeto de estudo faz com que seja necessária a montagem de um referencial, a partir do uso de "indicadores". Os

indicadores ajudam a representá-la nos elementos e componentes que podem 
constituí-la, elementos e componentes que referem assuntos materiais e imateriais da vida dos sujeitos sociais.

Há uma tendência de reduzir os indicadores aos elementos quantitativos que configuram a discussão da qualidade de vida e desenvolvimento humano. Onde se elimina a perspectiva qualitativa e se elimina a relação objetividade-subjetividade que revela os aspectos da realidade em que se vive.

Contrapondo o genérico e unilateral indicador Produto Interno Bruto (PIB) per capita como indicador de nível de desenvolvimento sócio-econômico, diferentes pesquisadores e organismos internacionais passaram a propor e testar outros indicadores substitutos.

Dentre as várias propostas desenvolvidas, os estudos realizados nos anos 1960 no Instituto de Pesquisa e Desenvolvimento Social das Nações Unidas (UNRISD), para construção de um indicador quantitativo de nível de vida, parecem ser aqueles que mais tarde vieram influenciar de forma decisiva para definição do Índice de Desenvolvimento Humano (IDH) do PNUD, nos anos 1980. Na então proposta do método genebriano de medição de grau de satisfação das necessidades materiais e culturais da população já figuravam as dimensões sociais, forma de cômputo baseado em diferenças, na relação valores-limite e método de agregação de indicadores parciais em índices sintéticos, usados no IDH.

Vale ressaltar que as pesquisas e bancos de dados compilados por outras instituições multilaterais como Banco Mundial, Organização Mundial da Saúde e UNICEF, também foram importantes no provimento das informações básicas usadas no cômputo do IDH e nos estudos a ele associados (JANNUZZI, 2004). 
Ademais, a utilização de diversos indicadores para avaliar as condições de vida da população em unidades espaciais menores (nacional, regional e posteriormente municipal) é cada vez mais freqüente e é usada como instrumento de políticas públicas essenciais para a transformação da sociedade (NAHAS, 2002).

Neste sentido, procura-se ultrapassar um foco da passividade de objetosujeito que se quantifica, indicando qual é o número do desenvolvimento. De toda sorte não nos imiscuímos de realizar a quantificação dos dados de campo como mecanismos de estabelecer apontamentos sobre sua limitação.

\subsection{As dimensões do desenvolvimento humano no campo e na cidade}

A trajetória de análise das condições sociais de reprodução humana sempre teve como fundamento a questão econômica, não obstante o PIB se colocara como uma representação de uma riqueza monetária "distributiva" à população de um país, região ou cidade.

Como indica Torres (2003), esse entendimento de que o PIB per capita é uma medida insuficiente para avaliar a qualidade de vida das pessoas, já estava evidente na década de 50, quando em 1954 um grupo de especialistas das Nações Unidas propôs que, além da dimensão monetária, outras dimensões deveriam ser consideradas na avaliação da qualidade de vida das pessoas.

Neste sentido, Koga (2003:83) aponta que na década de 1990 a relação espaço/território e meio ambiente foram introduzidas nos estudos sobre condições de vida. Afirma ainda que, a construção pelo PNUD, em 1990, do IDH, rompeu com o tradicional índice comparativo entre os países, pautado no genérico e unilateral 
PIB per capita. Salienta Torres (2003), que como essa idéia se baseia no pressuposto de progresso de um país ou localidade não pode ser mensurado apenas pelo dinheiro que possuem (ou carecem) seus cidadãos, mas também em sua saúde, na qualidade dos serviços médicos e em sua educação. Essas medidas deverão ser consideradas não só pela disponibilidade, mas também pela qualidade dos serviços que lhes são prestados.

Da mesma forma, é necessário conhecer as condições de trabalho, quais direitos legais e políticos usufruem seus cidadãos, que liberdades possuem para conduzir suas relações sociais e pessoais, como se estruturam as relações familiares e entre os gêneros e como estas estruturas promovem ou dificultam outros aspectos da atividade humana. E, sobretudo, saber de que forma a sociedade em questão permite às pessoas imaginar, maravilhar-se e sentir emoções, o que efetivamente faz com que a vida seja mais do que um conjunto de relações comerciais (NUSSBAUM; SEN, 1998) e abarque dimensões subjetivas fundamentais a esse desenvolvimento.

No âmbito das vantagens proporcionadas pelo IDH, Guimarães e Jannuzzi (2004) destacam que "o reduzido número de dimensões utilizados na construção do índice tem servido para manter a simplicidade de entendimento do mesmo, o que tem se constituído num fator muito importante de sua transparência e de simplicidade para transmitir seu significado a um público amplo e diversificado". Ademais, segundo os autores, o IDH tem permitido a construção de modelos visuais que facilitam a comparação entre diferentes regiões ou diferentes momentos no tempo. Por fim afirmam que "o IDH também teve o mérito de sinalizar aos gestores públicos que o alcance do progresso não é sinônimo exclusivo de crescimento 
econômico, ou seja, de exclusivamente incrementar a produção de bens e serviços". Nesse contexto, foi possível introduzir o debate de que, pelo menos, a melhoria das condições de saúde e educação da população deve também ser considerada como integrante do processo de desenvolvimento (GUIMARÃES; JANNUZZI, 2004, p.4).

Logo, a discussão acerca dos indicadores sociais deve romper com uma lógica que seja restrita à mensuração do desenvolvimento humano e que por muitas vezes se exime da responsabilidade de fazer uma leitura crítica da realidade, onde condições objetivas e subjetivas estão dadas aos sujeitos em seu dia-a-dia. Desta forma os indicadores devem sim revelar o que de fato deve ser feito ou refeito no que tange especialmente às políticas públicas de educação, saúde, renda e trabalho. 


\subsubsection{A dimensão educação nos assentamentos e na periferia}

“... A educação é o ponto em que decidimos se amamos o mundo o bastante para assumirmos a responsabilidade por ele..."

(ARENDT, 1972)

Brandão (1995) afirma que, em todas as sociedades é a educação um dos mais efetivos instrumentos de controle social. "Os seus conteúdos de efeito socializador em geral conduzem mensagens que legitimam uma ordem social vigente. Isto significa que, ao ensinar alguma coisa a algumas pessoas, a educação ensina os termos de uma ordem social que deve ser reconhecida como necessária e legitima, na mesma medida em que ensina os conhecimentos e as habilitações necessárias e legitimas para que as pessoas da sociedade preservem e reconstruam, com as suas idéias (próprias, mas inculcadas pela educação) e com as suas atitudes (aprendidas, mas sob a forma de controle exercido pela sociedade através da educação), a ordem econômica, política e ideológica da sociedade" (BRANDÃO, 1995).

Para Arendt (1972: 245) o problema da educação no mundo moderno está no fato de, por sua natureza, não poder abrir mão nem da autoridade, nem da tradição, e ser obrigada, apesar disso, a caminhar em um mundo que não é estruturado nem pela autoridade nem tampouco mantido coeso pela tradição. Para a autora isso significa, entretanto, que não apenas professores e educadores, porém todos nós, na medida em que vivemos em um mundo junto à nossas crianças e aos jovens, devemos ter em relação a eles uma atitude radicalmente diversa da que guardamos um para com o outro. Cumpre divorciarmos decisivamente o âmbito da educação dos demais, e acima de tudo do âmbito da vida pública e política, para aplicar 
exclusivamente a ele um conceito de autoridade e uma atitude face ao passado que Ihe são apropriados mas não possuem validade geral, não devendo reclamar uma aplicação generalizada no mundo dos adultos (ARENDT, 1972 p. 245; 246).

Salienta-se, neste momento, a necessidade de avançar para além de uma perspectiva formal, dada à educação por Brandão (1995) e Arendt (1972), aonde a escola se apresenta como um aparelho ideológico de Estado (ALTHUSSER, 1980) e pôr-se a caminho de uma educação que respeita os saberes prévios dos sujeitos, conhecimento adquirido por meio das trocas (objetivas e subjetivas) apreendidas no cotidiano e especialmente no caráter teleológico atribuído pelos sujeitos a essa dimensão.

Isto é, para discutirmos a dimensão educação nos assentamentos e na periferia destaca-se a necessidade de entender a educação, também, enquanto um fator emancipador e nesse sentido há uma singular importância que deverá ser aferida à educação não formal - não por oposição à educação formal, mas sim como Gadotti (2005:2) afirma por uma educação mais difusa, menos hierárquica e menos burocrática - a qual assume um caráter transformador da realidade dos sujeitos.

Daí o vínculo que se pretende traçar entre o que o Índice de Desenvolvimento Humano propõe como uma análise da educação (baseado no cálculo de dois indicadores, onde o primeiro indica a taxa de alfabetização de pessoas acima de 15 anos de idade capazes de ler e escrever um bilhete simples, considerados adultos alfabetizados, e o segundo, trata-se do resultado de uma conta simples: a somatória do número de pessoas, independentemente da idade, que freqüentam a escola, dividido pela população na faixa etária de 7 a 22 anos) e aquilo que se pondera por meio de uma análise qualitativa, verificando as inter-relações que se estabelecem na 
perspectiva da educação para o desenvolvimento dos sujeitos. Nesse sentido discute-se a respeito do abandono escolar, alfabetização e inclusão digital e a importância dada pelos sujeitos à educação para seu desenvolvimento.

\section{a) Importância da educação}

A educação, de acordo com $100 \%$ dos entrevistados se apresenta como um indicador indispensável para a aferição do desenvolvimento humano, isto é, em concordância com os respondentes, tanto no campo quanto na cidade, o grau de importância dado à educação para o desenvolvimento, em uma escala de zero a dez, é dez.

Os entrevistados justificaram esta relevância dada à educação dizendo entre outras coisas que: "A educação traz tudo, da conquista do trabalho ao saber conversar com alguém, ela é o principal"; "a educação transforma as pessoas e faz com que elas se relacionem melhor com os outros". Como também disseram, "a educação vai além da formação na escola ela está firmemente unida aos valores de formação, especialmente àqueles "que se aprende em casa", isto é, "a educação que vem do berço" (Tabela 03). 
Tabela 03: Freqüência das respostas dadas à pergunta "Por que a educação é importante para o seu desenvolvimento?" nos assentamentos rurais e na área periférica urbana do município de Ribeirão Preto (\%).

\section{IMPORTANCIA DA EDUCACÃO}

LOCAL

Ass.Mario Lago

Ass. Sepé Tiarajú

Área periferia $(n-13)$
A educação traz tudo;

(da conquista do trabalho ao saber conversar com alguém, é o principal);

A educação transforma as pessoas e faz com que elas se relacionem melhor com os outros.

\section{Para aprender} os valores da vida;

(família)



\begin{tabular}{llll} 
Ass.Mario Lago & 57,1 & 23,80 & 21,4 \\
Ass. Sepé Tiarajú & 75,0 & 0,00 & 25,0 \\
\cline { 2 - 4 } Área periferia (n-13) & 60,0 & 20,0 & 34,3 \\
\hline
\end{tabular}

Fonte: Trabalho de Campo Fev - Jun 2009.

Organização: Natália Freire Bellentani

A realidade concreta e contraditória que envolve o campo e a cidade nos revela a valoração dada à educação para o desenvolvimento humano pelos entrevistados. A importância da educação está ligada a uma relação intrínseca entre o trabalho e a educação, ou seja, na área de periferia urbana há uma conexão muito imediata entre a educação e oportunidade de emprego e/ou aumento salarial; no campo, isso também ocorre em alguns casos, mas não com a intensidade que foi percebida na cidade. Nos assentamentos, o valor dado à educação muitas vezes ultrapassa essa relação trabalho-educação, se ligando diretamente às questões de valores humanos, como por exemplo, respeito, dignidade, tolerância, honestidade, solidariedade, companheirismo e responsabilidade. 
Interessante este ponto ser ressaltado, tendo em vista que no estudo preparado pelo Programa das Nações Unidas para o Desenvolvimento (PNUD) no Brasil, para a elaboração do Relatório de Desenvolvimento Humano no Brasil 2010, em uma pergunta central sobre "do que o país mais precisa para melhorar" teve como resposta: valores. De acordo com Racy (2009), o coordenador do trabalho, Flávio Comin, não escondeu a surpresa e revelou que questões como salário, saúde, emprego ou segurança perderam para menções sobre a importância de honestidade, responsabilidade, paz, valor espiritual, respeito, ausência de preconceito.

Reforçando desta maneira uma perspectiva que revela elementos (subjetivo/objetivos) que devem ser incorporados a uma discussão que envolva o desenvolvimento humano, para além de uma dimensão simplesmente matemática.

\section{b) Cálculo do IDH-Educação}

Como referido anteriormente esta dimensão do Índice de Desenvolvimento Humano - IDH é formada por dois indicadores, onde o primeiro indica a taxa de alfabetização de pessoas acima de 15 anos de idade capazes de ler e escrever um bilhete simples, considerados adultos alfabetizados, e o segundo, trata-se do resultado de uma conta simples: a somatória do numero de pessoas, independentemente da idade, que freqüentam a escola, dividido pela população na faixa etária de 7 a 22 anos (Tabela 04 e 5). 
Tabela 04: Idade (média) dos pais e filhos (com 15 ou mais) e respectiva média anual de escolarização nos assentamentos rurais e na área periférica urbana do município de Ribeirão Preto (\%).

\begin{tabular}{lllll}
\hline LOCAL & \multicolumn{2}{l}{ IDADE MÉDIA } & \multicolumn{2}{l}{ MÉDIA ANUAL DE ESCOLARIZAÇÃO } \\
\cline { 2 - 5 } Ass. Mario Lago & Pais & 50 & Pais & 05 \\
& Filhos $^{*}$ & 20 & Filhos & 10 \\
Ass. Sepé Tiarajú & Pais & 52 & Pais & 04 \\
& Filhos & 21 & Filhos & 09 \\
& & & & \\
Área periferia (n-13) & Pais & 44 & Pais & 05 \\
& Filhos & 20 & Filhos & 10 \\
\hline
\end{tabular}

* com 15 anos ou mais

Fonte: Trabalho de Campo Fev - Jun 2009.

Organização: Natália Freire Bellentani

Tabela 05: Cálculo do IDH-Educação baseado na taxa de freqüência à escola e pecentagem da alfabetização dos assentamentos rurais e na área periférica urbana do município de Ribeirão Preto.

\begin{tabular}{lccc}
\hline LOCAL & $\mathbf{F}^{*}$ & $\begin{array}{c}\mathbf{A}^{* *} \\
(\%)\end{array}$ & $\begin{array}{c}\text { IDH-Educação } \\
{[\mathbf{F + ( 2 X a ) ] / 3}}\end{array}$ \\
\cline { 2 - 4 } Ass.Mario Lago & 1,05 & 12,0 & 0.403 \\
Ass. Sepé Tiarajú & 1,12 & 8,0 & 0.453 \\
Área periferia (n-13) & 0,92 & 6,8 & 0.352 \\
\hline
\end{tabular}

$F^{*}$ : freqüência à escola (número de pessoas -de qualquer idade- que freqüentam a escola, dividido pelo número de pessoas com idade de 7 a 22 anos.)

$A^{\star *}$ : \% alfabetização (percentagem de pessoas com idade maior ou igual a 15 anos analfabetas.)

Fonte: Trabalho de Campo Fev - Jun 2009.

Organização: Natália Freire Bellentani

Os valores do indicador de educação das áreas variou entre 0,352 para os bairros de periferia e 0,453 para o assentamento "Sepé Tiarajú" sendo que para o assentamento "Mário Lago" esse foi de 0,403 , todos considerados baixos. Lembrando que em 2000 o cálculo do IDH-Educação para município de Ribeirão Preto, foi de 0,918 , índice considerado alto e o município do estado de são Paulo que apresentou menor índice foi Barra do Turvo, com IDH-E igual a 0,755 (Tabela 06). 
Tabela 06: Cálculo -referente ao ano de 2000- do IDH-Educação do município de Ribeirão Preto e municípios com maior e menor índice do estado de São Paulo (IPEA, 2000).

\begin{tabular}{lccc} 
& Ribeirão Preto & Município maior IDH-E & Município menor IDH-E \\
\cline { 2 - 4 } IDH - Educação & $\mathbf{0 , 9 1 8}$ & 0,975 & 0,755 \\
& & (S. Caetano do Sul) & (Barra do Turvo) \\
\hline
\end{tabular}

Fonte: Instituto de Pesquisa Econômica Aplicada (IPEA) 2000.

Organização: Natália Freire Bellentani

Consideramos sempre importante ressaltar que a dimensão da educação, para o IDH, é dada sob uma perspectiva que se contabiliza e procura responder a questões referentes a uma lógica formal, atribuída especialmente às escolas, não se importando com uma educação de caráter transformador da realidade, que se estabelece no interior das práticas cotidianas, por meio da educação não-formal.

No caso da periferia a educação não formal revela-se muitas vezes em meio as canções de RAP que os adolescentes, jovens e crianças aprendem uns com os outros e que com orgulho cantam juntos nas esquinas do bairro, principalmente nos horários (de saída e entrada das aulas ou durante a espera do ônibus - Foto 06) em que se reúnem nas esquinas próximas às escolas. Um exemplo concreto se configura nesse rap cantado no ônibus circular -que ia do bairro em direção ao centro- em um dos dias de trabalho de campo: "Não posso nem parar, não posso me estressar, tenho que continuar a responsa vai mostrar e provar que a consciência ainda está firmeza, a maioria na quebrada ainda é fogo na madeira, mano inteligente tipo A, [...], no mundo aí a fora eu sei RAP É COMPROMISSO!" (Garoto do bairro Jd Salgado Filho 1, 13 anos). 


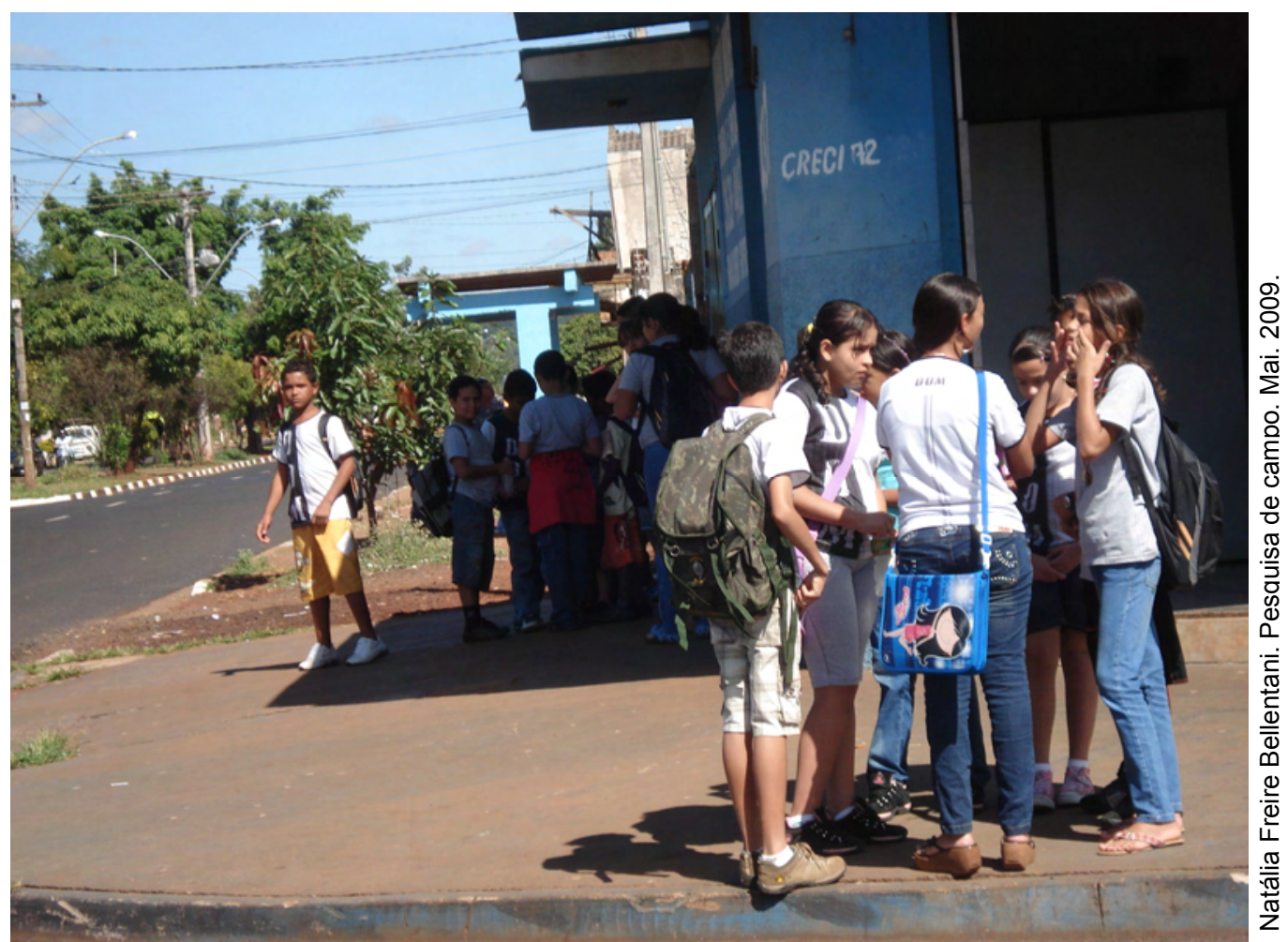

FOTO 06: O ponto de ônibus e de encontro na periferia de Rib. Preto - Mai. 2009.

Ainda nos bairros é possível verificar que a solidariedade não é aprendida nos bancos escolares, mas sim dentro das casas. Quando algo grave acontece seja com qual família for, se estabelece entre os moradores do bairro uma rede concreta de solidariedade, e eles se ajudam mutuamente e isso as crianças aprendem e também reproduzem em suas atitudes. Mesmo que em bairros com focos de violência como no Jd Salgado Filho 1 e no Jd Aeroporto, a cumplicidade e a solidariedade entre os sujeitos também são transmitidas, como um valor de formação.

Essa transmissão cultural no caso dos assentamentos se revela em meio as conversas dos mais jovens com os mais velhos, aonde é possível aprender técnicas de cultivo, "seleção massal" (a escolha das melhores plantas para guardar as melhores sementes para a próxima safra), histórias, cantorias e acordes de viola. Entre todos os aprendizados ("de fora da escola", como gostam de dizer) no 
assentamento "Mario Lago" foi possível verificar um troca singular de culturas entre as famílias, por exemplo, famílias vindas de Minas Gerais trocando experiências e vivências com a família -agora vizinha de lote- vinda do Maranhão. Para configurar de forma concreta esse exemplo podemos destacar que e erva utilizada pela primeira família para fazer o chá medicinal é utilizada pela segunda para temperar carne de porco, e assim muitas trocas e aprendizados e sementes se dão no cotidiano do lugar, pautando a educação não formal no dia-a-dia desses sujeitos.

Contudo, ressalta-se que o esforço empreendido pelos pais em relação à educação dos filhos, como mencionado anteriormente, é um fato que exprime de maneira singular a importância dada pelos sujeitos à educação.

Esta dimensão, tão cara ao desenvolvimento humano, revela elementos qualitativos que permitem considerar a educação para além de uma questão utilitarista, apontando para uma educação que permita efetivamente a emancipação dos sujeitos e, portanto a sua concreta formação.

Em vista disso, salienta-se que algumas diferenças entre as áreas só aparecem, ou aparecem de maneira mais acentuada, quando são tratadas sob uma ótica que também contemple componentes qualitativos para a averiguação do desenvolvimento humano, como é o caso, por exemplo, do abandono escolar; atividades complementares; alfabetização digital; entre outros elementos que superam a perspectiva quantitativa do índice.

\section{c) Abandono escolar}

O Relatório divulgado no ano de 2009 pelo Unicef (Fundo das Nações Unidas para a Infância) mostra que o Brasil registrou avanços importantes na educação nos 
últimos 15 anos. Cerca de 27 milhões de estudantes estão nas salas de aula, o que corresponde a $97,6 \%$ das crianças entre sete e 14 anos. Mas, o Unicef também chama a atenção para o fato de que a parcela ainda fora da escola $(2,4 \%)$ representa 680 mil brasileiros nessa faixa etária.

Segundo o documento, "as desigualdades presentes na sociedade ainda têm um importante reflexo no ensino brasileiro". O relatório alerta que são os grupos mais vulneráveis da população que enfrentam dificuldades para ter acesso à educação e concluir os estudos (UNICEF, 2009).

De acordo com Ferreira (2009) existem diferentes perspectivas na abordagem do conceito de abandono escolar, todavia, como afirma o autor considera-se abandono escolar quando um aluno deixa de freqüentar a escola, por motivos que não sejam a sua morte ou transferência para outro estabelecimento de ensino, sem o ter concluído. E ressalta ainda que, esta questão do abandono escolar não pode ser encarada apenas como uma simples desistência, mas sim como um problema social bastante complexo, tanto nas suas causas como nas suas conseqüências.

Neste sentido, para o Unicef (2009) além da baixa qualidade do ensino, uma série de fatores relacionados à pobreza e à discriminação pode levar crianças e adolescentes a deixar a escola antes da conclusão dos estudos. Salienta-se que o trabalho precoce é um sério motivo que leva crianças e adolescentes a abandonarem a escola. De acordo com a Pesquisa Nacional por Amostra de Domicílios (PNAD), do IBGE, 2007, do total de 44,7 milhões de crianças e adolescentes de cinco a 17 anos de idade, 4,8 milhões trabalham. Quase um terço $(30,5 \%)$ desse grupo trabalha pelo menos 40 horas semanais (UNICEF, 2009). 
A necessidade de trabalhar é igualmente vista pelos entrevistados tanto no campo quanto na cidade como sendo o principal motivo apontado para o abandono da escola (nos assentamentos em média $68 \%$ e na área periférica urbana 62,9\%). Mas este fator não se configura apenas por uma questão estritamente econômica, tanto que alguns motivos se completaram, como por exemplo, o fato de não dar a devida importância aos estudos (nos assentamentos em média 12\% e na área periférica urbana $20,0 \%$ ), ou ainda por ter casado, ter tido filhos (nos assentamentos em média $10 \%$ e na área periférica urbana $15,7 \%$ ), ou mesmo pelas distâncias entre onde se morava e a escola, enfim fatores que são confrontados com a questão da importância dada para a educação hoje e o esforço dos pais para que os filhos tenham antes de tudo, a educação (Tabela 07).

Tabela 07: Principais motivos de abandono escolar nos assentamentos rurais e na área periférica urbana do município de Ribeirão Preto (\%).

\begin{tabular}{|c|c|c|c|c|}
\hline \multirow[b]{2}{*}{ LOCAL } & \multicolumn{4}{|c|}{ MOTIVO ABANDONO } \\
\hline & $\begin{array}{l}\text { Mobilidade } \\
\text { (mudava com } \\
\text { freqüência; morava } \\
\text { muito longe) }\end{array}$ & $\begin{array}{l}\text { Condições pessoais } \\
\text { (casamento, filhos, perda de } \\
\text { parentes, dificuldades } \\
\text { financeiras) }\end{array}$ & Trabalho & $\begin{array}{c}\text { Não quis mais } \\
\text { (não dava } \\
\text { importância) }\end{array}$ \\
\hline Ass. Mario Lago & 14,3 & 11,9 & 69,4 & 9,52 \\
\hline Ass. Sepé Tiarajú & 37,5 & 0,00 & 62,5 & 25,0 \\
\hline Área periferia $(n-13)$ & 7,14 & 15,7 & 62,9 & 20,0 \\
\hline
\end{tabular}

Conforme o Unicef (2009) o abandono da escola em razão da necessidade de trabalhar para ajudar na renda familiar é um motivo bastante marcante. $E$ isto 
também ficou evidente quando se observa a taxa de escolarização dos adolescentes ocupados e não ocupados no Brasil. De acordo com a Pesquisa Nacional por Amostra de Domicílios, 2007, dos adolescentes de 15 a 17 anos que trabalham, apenas $21,8 \%$ estão na escola. Como vamos verificar adiante, tanto no campo como na cidade, na faixa etária entre zero a 15 anos não houve relatos de crianças e/ou adolescentes que trabalhem. O que não significaria dizer que essas criança/adolescentes não realizam tarefas domésticas ou até mesmo os trabalhos do campo que não depreciativos e que pudessem configurar qualquer tipo de exploração e/ou "trabalho infantil". Entre 15 e 30 anos, na área de periferia cerca de $31,4 \%$ dos entrevistados trabalham. Já nos assentamentos para esta mesma faixa etária o resultado apontou para $30 \%$. Em uma faixa etária maior, variando entre 31 e 60 anos, encontra-se a maior parte das pessoas que trabalham. Em média nos assentamentos $78 \%$ e na área de periferia urbana $82,9 \%$ dos entrevistados trabalham.

Tabela 08: Idade média das pessoas que trabalham nos Assentamentos Rurais e Área Periférica do Município de Ribeirão Preto (\%).

\section{$\underline{\text { LOCAL }}$}

IDADE

\begin{tabular}{lcccc}
\cline { 2 - 4 } & $\mathbf{0 \_ 1 5}$ & $>16 \_30$ & $>31 \_60$ & $>61$ \\
\cline { 2 - 5 } Ass. Mario Lago & 0,00 & 23,8 & 73,8 & 35,7 \\
Ass. Sepé Tiarajú & 0,00 & 62,5 & 100 & 25,0 \\
\cline { 2 - 4 } & 0,00 & 31,4 & 82,9 & 1,42
\end{tabular}

Fonte: Trabalho de Campo Fev - Jun 2009. 
Deve-se ressaltar também que não houve declarações referentes à ocorrência de trabalho infantil, tanto nas áreas estudadas do campo como da cidade, confirmando aquilo que foi apontado na dimensão educação do índice, que diz respeito a um esforço concreto dos pais para que seus filhos estudem e se possível trabalhem apenas depois dos 15 anos.

No entanto ressaltamos aqui que tanto nos assentamentos como na periferia as crianças trabalham, mas não constatamos que estas sejam exploradas, o que configuraria o trabalho infantil, em seu sentido estrito. Na cidade, por exemplo, elas ajudam nas atividades domésticas e no campo, além disso, também contribuem com algumas atividades do campo, como por exemplo, plantio e colheita.

Além disso, o que nos chama a atenção é o fato de que os sujeitos com mais de 60 anos nos assentamentos, em média 34\%, continuam em atividade permanente, em contraposição à cidade, onde apenas $1,42 \%$ dos respondentes trabalham. Esta diferença está relacionada ao sentido que o trabalho tem no campo, aproximando os sujeitos de suas realizações pessoais, especialmente por meio da reforma agrária. E desta forma, para essas pessoas (34\%) com mais de 60 anos, assentadas, parar de trabalhar significaria, parar de viver.

Com isso percebemos que além das atividades referentes ao ensino formal e ao abandono do mesmo houve a necessidade de abrirmos uma discussão junto às famílias acerca das atividades complementares relacionadas à educação que as mesmas desenvolvem, para isso questionamos sobre freqüência à biblioteca e hábitos de leitura; atividades complementares e alfabetização digital.

Em todos os casos, tantos nos assentamentos como na periferia, $100 \%$ dos entrevistados disseram que quando existe a oportunidade de um ou mais membros 
da família irem à biblioteca (normalmente os filhos que estão na escola) eles o fazem na própria biblioteca da escola. No assentamento "Mário Lago" 21,42\% das famílias tem ao menos um membro (ou mais) que freqüenta a biblioteca. Destes, $66,66 \%$ vão porque gostam de ler, outros 33,33\% vão porque os professores levam. No assentamento "Sepé Tiarajú" $50 \%$ das famílias que têm ao menos um membro (ou mais) que freqüenta a biblioteca, $75 \%$ vão porque gostam de ler e $25 \%$ vão porque os professores levam como podemos verificar na Tabela 09.

Tabela 09: Famílias que freqüentam bibliotecas, nos assentamentos rurais e na área periférica urbana do município de Ribeirão Preto (\%).

\begin{tabular}{|c|c|c|c|c|c|}
\hline \multirow[t]{2}{*}{ LOCAL } & \multirow{2}{*}{$\begin{array}{c}\text { No FAMÍLIAS }^{*} \\
\text { FREQUENTAM } \\
\text { BIBLIOTECA (\%) }\end{array}$} & \multicolumn{2}{|c|}{ MOTIVOS (\%) } & \multicolumn{2}{|c|}{ LOCAL (\%) } \\
\hline & & $\begin{array}{l}\text { gosta } \\
\text { de ler }\end{array}$ & $\begin{array}{l}\text { profs. } \\
\text { levam }\end{array}$ & $\begin{array}{l}\text { própria } \\
\text { escola }\end{array}$ & $\begin{array}{l}\text { biblioteca } \\
\text { municipal }\end{array}$ \\
\hline $\begin{array}{l}\text { Ass.Mario } \\
\text { Lago }\end{array}$ & $21,42 \%$ & 66,66 & 33,33 & 100 & - \\
\hline $\begin{array}{l}\text { Ass. Sepé } \\
\text { Tiarajú }\end{array}$ & $50,00 \%$ & 75,00 & 25,00 & 100 & - \\
\hline $\begin{array}{l}\text { Área periferia } \\
(n-13)\end{array}$ & $15,71 \%$ & 18,18 & 81,81 & 100 & - \\
\hline
\end{tabular}

* um ou mais membros da família freqüenta $(\mathrm{m})$ a biblioteca com freqüência regular.

Fonte: Trabalho de Campo Fev - Jun 2009.

Organização: Natália Freire Bellentani

No assentamento "Mário Lago" a freqüência das visitas é superior a seis vezes por ano à biblioteca e o grau de satisfação está em torno de nove, já no assentamento "Sepé Tiarajú a freqüência das visitas é pelo menos uma vez por mês e o grau de satisfação também está em torno de nove. Na periferia a 
freqüência das visitas é de mais de seis vezes por ano à biblioteca e o grau de satisfação está em torno de oito.

Quanto às atividades complementares praticadas pelas famílias (um ou mais membros), obtivemos respostas relacionadas à prática de esportes, dança, música, aprendizado de línguas estrangeiras e cursos de informática (Tabela 10).

Tabela 10: Famílias que praticam atividades complementares nos assentamentos rurais e na área periférica urbana do município de Ribeirão Preto (\%).

\begin{tabular}{|c|c|c|c|c|c|c|c|c|c|c|c|}
\hline \multirow[t]{2}{*}{ LOCAL } & \multirow{2}{*}{$\begin{array}{c}\text { N}^{\circ} \text { FAMÍLIAS } \\
\text { PRATICAM } \\
\text { ATIV. COMPL. } \\
(\%)\end{array}$} & \multicolumn{5}{|c|}{$\begin{array}{c}\text { O QUE PRATICA? } \\
(\%)\end{array}$} & \multicolumn{5}{|c|}{$\begin{array}{c}\text { QUEM PROMOVE? } \\
(\%)\end{array}$} \\
\hline & & 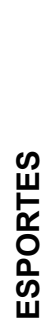 & 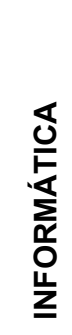 & 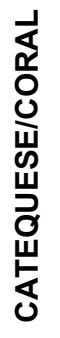 & 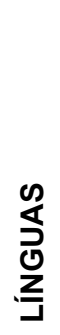 & 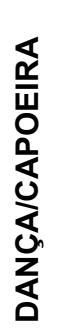 & 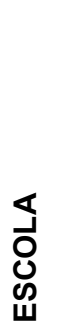 & 0 & $\stackrel{5}{\Sigma}$ & $\begin{array}{l}\overleftarrow{J} \\
\text { 崩 } \\
\underline{0}\end{array}$ & 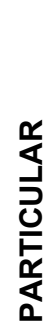 \\
\hline $\begin{array}{l}\text { Ass.Mario } \\
\text { Lago }\end{array}$ & 11,42 & $\stackrel{\sim}{N}$ & $\stackrel{\sim}{N}$ & 1 & $\stackrel{N}{N}$ & $\stackrel{\sim}{N}$ & 유 & ' & 우 & ' & ' \\
\hline $\begin{array}{l}\text { Ass. Sepé } \\
\text { Tiarajú }\end{array}$ & 25,00 & ' & 음 & ' & ' & ' & ' & ' & ' & 1 & 음 \\
\hline $\begin{array}{l}\text { Área } \\
\text { periferia } \\
(n-13)\end{array}$ & 9,52 & กู & ' & $\stackrel{10}{N}$ & ' & $\stackrel{10}{\stackrel{1}{2}}$ & ' & ชี & $'$ & $\stackrel{\sim}{N}$ & $\stackrel{10}{\stackrel{n}{2}}$ \\
\hline
\end{tabular}

No assentamento "Mário Lago" dos $11,42 \%$, pelo menos $25 \%$ praticam atividades relacionadas ao esporte, na periferia esse número chegou a $62 \%$, ou seja dos $9,52 \%$ que declaram ter ao menos um membro (ou mais) que realizam algum 
tipo de atividade complementar, 62,5\% estão relacionadas aos esporte. Ainda na periferia foi possível verificar que também nas igrejas desenvolvem-se esse tipo de atividades, seja o coral ou a catequese, chegando a $25 \%$ na relação de atividades praticadas. Além disso, tantos nos bairros periféricos $(12,5 \%)$ como no assentamento "Mário Lago" (25\%) realiza-se a prática de dança e/ou capoeira, desenvolvida ou por ONGs, no caso da periferia, ou pelo próprio movimento social no caso do assentamento. No assentamento "Sepé Tiarajú" dos $25 \%$ das famílias que tem ao menos um membro (ou mais) que praticam atividades complementares, $100 \%$ destas atividades estão relacionadas com o aprendizado da informática, no "Mário Lago" esse valor está em torno de $25 \%$ e na periferia não foi possível verificar resultados ligados à alfabetização digital (cursos esses promovidos pelas escolas ou pagos, em casos de cursos particulares). Tendo em vista que há uma forte demanda por esse tipo de aprendizagem também discutimos a respeito da alfabetização digital com as famílias e a seguir será possível verificar uma relação extremamente forte entre a escolaridade média e a alfabetização digital.

\section{d) Alfabetização digital}

O Mapa das Desigualdades Digitais (2007) registra que, no Brasil, as pessoas com computador no domicílio passaram de 12,5\% em 2001 para 18,5\% em 2005 crescimento de $38,4 \%$ da mesma forma que pessoas com Internet domiciliar passaram de $8,3 \%$ para $13,6 \%$ - crescimento de $62,9 \%$ entre essas mesmas datas.

A maior parte dos alfabetizados digitais, no Assentamento Mário Lago está na faixa etária entre 15 e 30 anos, $24 \%$, sendo que essa mesma faixa no Assentamento 
"Sepé Tiarajú" concentrou cerca de $63 \%$ e na área de periferia urbana esse número ficou próximo a 43\%. Entre 7 e 15 anos, no Assentamento Mário Lago o resultado foi de $19 \%$ e entre 30 e 60 anos apenas 2\%. Para o Assentamento Sepé Tiarajú apresentou-se um resultado de forma um pouco diferente, verificou-se $63 \%$ na faixa etária entre 7 e 15 anos e entre 30 e 60 anos foi nulo, enquanto que na periferia entre 7 e 15 anos esse valor chegou a $19 \%$ e entre 30 e 60 anos 1\%. A faixa etária com mais de 60 anos não apresentou resultados (Tabela 11).

Tabela 11: Idade média dos alfabetizados digitais nos assentamentos rurais e na área periférica urbana do município de Ribeirão Preto (\%).

\section{IDADE}

LOCAL

\begin{tabular}{ccccccc}
\hline 7_15 & esc. $\mathbf{m}^{*}$ & 16_30 & esc. $\mathbf{m}$ & 31_60 & esc. $\mathbf{m}$ & $>61$ \\
\hline 19,0 & 7 & 23,8 & 9 & 2,38 & 6 & 0,00 \\
62,5 & 7 & 37,5 & 10 & 0,00 & 5 & 0,00 \\
\hline 18,6 & 5 & 42,9 & 9 & 1,42 & 5 & 0,00
\end{tabular}

Ass. Mario Lago

Ass. Sepé Tiarajú

Área periferia $(n-13)$

18,6

Média de escolarização, de acordo com a referida faixa etária, nos assentamentos rurais e área periférica do município de Ribeirão Preto (\%).

Fonte: Trabalho de Campo Fev - Jun 2009.

Organização: Natália Freire Bellentani

Como pudemos observar existe uma relação direta entre a média de escolarização e a inclusão digital. Na área de periferia urbana, por exemplo, 42,9\% dos respondentes que tem entre 15 e 30 anos e são alfabetizados digitais, apresentaram em média nove anos de escolarização, em contraponto a 1,42\% entre 30 e 60 anos que apresentaram em média cinco anos de escolarização. 
Observa-se que no caso do assentamento "Sepé Tiarajú" o alto número das famílias que possuem membros que praticam atividades complementares, está ligado com os incentivos dados pela Secretaria da Educação de Serra Azul ao tema informática, ainda que todos sejam cursos particulares, mesmo assim há um estímulo por parte dos professores para que os alunos realizem tais cursos, de acordo com os relatos colhidos durante o trabalho de campo.

Do ponto de vista de Cabral Filho (2006) a educação para a informática precisa ser planejada desde os primeiros níveis de ensino. Sem preconceitos ou imposições, sem substituir o analógico pelo digital, mas reforçando a capacidade cognitiva dos alunos e guiando a descoberta de novos horizontes. O autor afirma ainda que "o acesso aos meios deve estimular a capacidade produtiva, apresentando os mais diferentes recursos e serviços disponíveis, sendo que, para isso, é necessária uma atualização constante dos professores, pedagogos e técnicos que trabalham com o conteúdo" (CABRAL FILHO, 2006).

Lembrando que o acesso ao meio digital se demonstra como uma alternativa que funciona para o acesso a informações e também se configura como um mecanismo de diálogo entre os sujeitos.

De acordo com o Ministério das Comunicações (2009), existe uma necessidade de ampliar a inclusão digital, reforçando a implantação de mais telecentros comunitários nas cidades espalhadas pelo território nacional e sustenta ainda que até o fim de 2010, todas as 56.720 escolas públicas urbanas do Brasil serão conectadas, beneficiando cerca de 37 milhões de estudantes, o que inclui $84 \%$ do alunado de ensino fundamental do Brasil, tendo em vista que o governo já conectou cerca de 30 mil escolas urbanas até agora. Todavia, o Mapa das 
Desigualdades Digitais (2007) sustenta que espaços que deveriam promover a democratização do acesso, como os computadores nas escolas para os alunos, e centros gratuitos de acesso para a população, beneficiam até agora, em maior medida, determinados grupos sociais, mais privilegiados economicamente. Considerando os grupos de menor renda o acesso via centros gratuitos é de $0,6 \%$, na faixa de renda desses grupos sociais mais privilegiados economicamente, esse índice ultrapassa $4 \%$. Entre os estudantes do ensino fundamental, só $2,5 \%$ dos mais pobres usaram computador na escola. Esse índice sobe para $37,3 \%$ no grupo de alunos de maior nível de renda (WAISELFISZ, 2007).

Para Cabral Filho (2006) incluir da perspectiva tecnológica envolve apreender o discurso da tecnologia, não apenas os comandos de determinados programas para a execução de determinados fins, não apenas qualificar melhor as pessoas para o mundo do trabalho, mas sim a capacidade de influir na decisão sobre a importância e as finalidades da tecnologia digital, o que em si é uma postura que está diretamente relacionada a uma perspectiva de inclusão/alfabetização digital, de política pública e de construção de cidadania, não apenas de quem consome e assimila um conhecimento já estruturado e direcionado para determinados fins (CABRAL FILHO, 2006).

Por fim, vale salientar que a defesa de uma educação que permita que os sujeitos revelem suas perspectivas de vida futura e que diga respeito não somente a uma visão utilitarista, como foi diagnosticado nos bairros de periferia, nos permitirá alcançar uma concepção qualitativa no processo de formação do desenvolvimento humano. 
Neste sentido, a importância dada pelos entrevistados à educação, bem como a realização do cálculo do índice e os elementos propostos para a superação do mesmo, nos auxilia em um processo que consolida concepções subjetivas para a qualidade de vida.

\subsubsection{A dimensão saúde (longevidade) nos assentamentos e na periferia}

Rufino Netto (1994) se refere à "boa ou excelente qualidade de vida" como aquela que ofereça um mínimo de condições para que os indivíduos nela inseridos possam desenvolver o máximo de suas potencialidades, sejam estas: viver, sentir ou amar, trabalhar, produzindo bens e serviços, fazendo ciência ou artes. Reforça ainda que, o que falta é o esforço de fazer da noção um conceito e torná-lo operativo.

Nesse sentido, a dimensão saúde na estruturação do Índice de Desenvolvimento Humano que se restringe a esperança de vida ao nascer, nesta pesquisa foi contemplada para além dos números da média de longevidade assumese um caráter qualitativo para dimensionar esta questão essencial.

Sendo assim, parte-se da expressão qualidade de vida ligada à saúde que foi definida por Auquier et al. (1997) como o valor atribuído à vida, ponderado pelas deteriorações funcionais; as percepções e condições sociais que são induzidas pela doença, agravos, tratamentos; e a organização política e econômica do sistema assistencial.

Minayo et al. (2000) reforçam que a versão inglesa do conceito de healthrelated quality of life (HRQL), em Gianchello (1996), é similar: é o valor atribuído à duração da vida quando modificada pela percepção de limitações físicas, 
psicológicas, funções sociais e oportunidades influenciadas pela doença, tratamento e outros agravos, tornando-se o principal indicador para a avaliação do resultado de intervenções.

Em vista disso, para a reflexão qualitativa da dimensão longevidade destacam-se questões centrais como: motivos dos falecimentos; de visitas médicas e freqüência; localização e acessibilidade ao médico; condições de saneamento (água, esgoto e lixo); alimentação e lazer.

De acordo com o Instituto Brasileiro de Geografia e Estatística (IBGE), em 1991, a expectativa de vida de um brasileiro era de 67 anos já em 2007 este número aumentou para 72,57 anos. Lembrando que muitas vezes estas médias se elevam em função de fatores que não são revelados, como por exemplo, o fato de que classes mais abastadas têm vivido mais, enquanto que, classes menos favorecidas continuam com a mesma expectativa de vida ou vivendo menos.

\section{a) Importância da saúde}

Como disse Coraggio (2000), a importância da expectativa de vida está na crença compartilhada de que uma vida longa é valiosa em si mesma e no fato de que vários benefícios indiretos estão associados com uma alta expectativa de vida.

Nesse sentido, de acordo com os entrevistados, pode-se dizer que a saúde bem como a educação são indicadores extremamente importantes para o desenvolvimento humano.

Tanto no campo como na cidade os respondentes quando questionados sobre o grau de importância da saúde relacionada ao seu próprio desenvolvimento aferiram nota máxima, em uma escala de zero a dez, à saúde. E ainda nos 
responderam porque consideram a saúde importante para o desenvolvimento humano (Tabela 12).

Tabela 12: Freqüência das respostas dadas à pergunta: "Por que a saúde é importante para o seu desenvolvimento?" nos assentamentos rurais e na área periférica urbana do município de Ribeirão Preto (\%).

IMPORTANCIA DA SAÚDE

LOCAL

\begin{tabular}{ccc}
\hline $\begin{array}{c}\text { PRINCIPAL } \\
\text { DA VIDA }\end{array}$ & POSSO & CAMINHA JUNTO \\
& TRABALHAR & COM A EDUCAÇÃO \\
\hline
\end{tabular}

Ass. Mario Lago

71,4

61,9

14,3

Ass. Sepé Tiarajú

62,5

87,5

0,00

Área periferia $(n-13)$

61,4

64,2

18,57

Fonte: Trabalho de Campo Fev - Jun 2009.

Organização: Natália Freire Bellentani

Dentre as respostas dadas o que mais nos chamou atenção foi o fato de que a grande maioria tanto no campo (Mário Lago: 61,9\%; Sepé Tiarajú: 87,5\%) como na cidade (Área periferia: 64,2\%), concentraram suas respostas acerca da saúde para o seu desenvolvimento relacionando-a ao trabalho. Ou seja, o grau de importância da saúde para o desenvolvimento humano que é dez - máximo- foi justificado na fala de um respondente, na periferia, dessa maneira: "Sem saúde não posso trabalhar, não ganho dinheiro e então não posso fazer nada, você sabe né, a vida do pobre não vale nada sem saúde." E essa resposta foi recorrente, a saúde atrelada a necessidade de trabalhar para obter a renda, foi sempre presente nas falas da periferia e dos assentamentos.

Porém, existe uma diferença muito significativa entre a relação dada ao trabalho e a saúde, na periferia, com aquela que foi identificada nos assentamentos. 
Isto se deve ao fato de que nos assentamentos, mesmo aqueles que responderam "que a saúde é o principal para a vida" (Mário Lago: 71,4\%; Sepé Tiarajú: 62,5\%; Área periferia: $61,4 \%$ ) e que sem a saúde não são absolutamente relacionaram essa dimensão com a necessidade de se manter saudáveis e vivos para poder trabalhar e garantir que participem de todo o processo de produção. Reforçando assim mais uma vez o trabalho como ponto fundamental do desenvolvimento.

Ainda houve quem dissesse que a saúde é importante para o desenvolvimento humano por que, caminha lado a lado da educação (Mário Lago: 14,3\%; Sepé Tiarajú: 0\%; Área periferia: 18,57\%), na opinião de um assentado: "para o nosso desenvolvimento a saúde caminha junto com a educação, nem o dinheiro é tão importante".

\section{b) Cálculo do IDH-Longevidade}

Para avaliar o desenvolvimento humano, como destacado anteriormente, no que diz respeito à longevidade, o Programa das Nações Unidas para o Desenvolvimento (PNUD) tem como variável a esperança de vida ao nascer, ou a idade média dos óbitos é o indicador fundamental para o cálculo do IDHlongevidade.

De acordo com o PNUD (2003), este indicador é uma boa forma de avaliar as condições sociais, de saúde e de salubridade por considerar as taxas de mortalidade das diferentes faixas etárias de determinada localidade.

Mas será possível determinar se sabemos alguma coisa a respeito da saúde de certa população, apenas por meio desse cálculo? 
Enfim, o cálculo do indicador longevidade que compõe o Índice de Desenvolvimento Humano foi realizado a partir dos dados coletados nos assentamentos rurais dos assentamentos rurais e na área periférica urbana do município de Ribeirão Preto (Tabela 13).

Tabela 13: Cálculo do IDH-Longevidade baseado na idade média dos óbitos nos assentamentos rurais e na área periférica urbana do município de Ribeirão Preto.

\begin{tabular}{lcc}
\hline LOCAL & MO* $^{*}$ & $\frac{\text { IDH-Longevidade }}{\text { MO-25/60 }}$ \\
\cline { 2 - 3 } & 65 & $\mathbf{0 . 6 6 0}$ \\
Ass.Mario Lago & 63 & $\mathbf{0 . 6 3 3}$ \\
Ass. Sepé Tiarajú & 64 & $\mathbf{0 . 6 5 0}$ \\
\hline Área periferia (n-13) & 63
\end{tabular}

MO*: idade média dos óbitos

Os valores do indicador de longevidade das áreas variou entre 0,633 para os para o assentamento "Sepé Tiarajú", 0,650 para os bairros de periferia e para o assentamento "Mário Lago" esse índice foi de 0,660, todos considerados médios. Lembrando que em 2000 o cálculo do IDH-Longevidade para município de Ribeirão Preto, foi de 0,823 , índice considerado alto e o município do estado de São Paulo que apresentou menor índice foi Barra do Chapéu, com IDH-E igual a 0,600 (Tabela 14) .

Tabela 14: Cálculo -referente ao ano de 2000- do IDH-Longevidade do município de Ribeirão Preto e municípios com maior e menor índice no estado de São Paulo (IPEA, 2000).

\begin{tabular}{cccc} 
& \multicolumn{1}{c}{ Ribeirão Preto } & Município maior IDH-L & Município menor IDH-L \\
\cline { 2 - 4 } IDH - Longevidade & $\mathbf{0 , 8 2 3}$ & 0,886 & 0,600 \\
& & (S. Caetano do Sul) & (Barra do Chapéu)
\end{tabular}

Fonte: Instituto de Pesquisa Econômica Aplicada (IPEA) 2000. Organização: Natália Freire Bellentani 
Compreende-se neste momento que a dimensão longevidade pautada pelo cálculo do IDH é gravemente restrita, já que se baseia apenas na esperança de vida ao nascer. A longevidade pode estar sujeita a variações que não são apreendidas pelo índice, como é o caso, por exemplo, da questão da correspondência que existe entre o nível sócio-econômico e a expectativa de vida, lembrando que em classes mais empobrecidas vive-se menos, em relação as classes mais abastadas.

Segundo o levantamento realizado nos assentamentos: "Mário Lago" e "Sepé Tiarajú", a expectativa de vida média foi 65 e 63 anos, respectivamente, enquanto que na área de periferia do município de Ribeirão Preto a longevidade média é de 64 anos (Tabela 15).

Tabela 15: Longevidade média da comunidade nos assentamentos rurais e na área periférica urbana do município de Ribeirão Preto.

LOCAL

LONGEVIDADE MÉDIA

Ass.Mario Lago

65

Ass. Sepé Tiarajú

63

Área periferia $(\mathrm{n}-13)$

Fonte: Trabalho de Campo Fev - Jun 2009.

Organização: Natália Freire Bellentani

Vale ressaltar que na área urbana pesquisada $17 \%$ dos entrevistados não tinham conhecimento acerca da origem paterna e, portanto não souberam informar a idade de óbito dos mesmos (não souberam responder se estes ainda são vivos ou mortos). Trata-se de uma interessante e importante verificação no que tange a questão da ausência paterna na formação da família, nos dias de hoje. Este fato não foi encontrado e/ou identificado nas áreas de assentamentos, sendo que todos os entrevistados destas áreas souberam responder acerca da idade e motivos dos falecimentos dos pais (Tabela 16). 
Tabela 16: Motivos dos falecimentos dos pais nos assentamentos rurais e na área periférica urbana do município de Ribeirão Preto.

causa mortis

(\%)

\section{$\underline{\text { LOCAL }}$}

Ass. Mario Lago
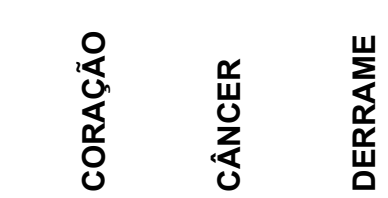

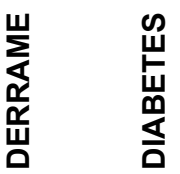

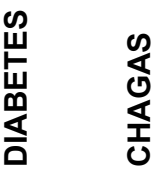

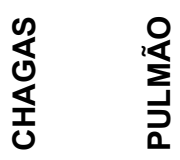

$\sum_{\substack{1 \\ 0}}^{0}$

崫

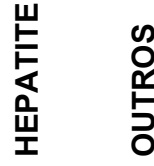

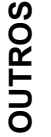

$30,95 \quad 11,90 \quad 16,66$

$9,52 \quad 9,52$

4,76

2,38

2,38

Ass. Sepé Tiarajú

25,00

12,50

12,50

12,50

25,00

Área periferia $(\mathrm{n}-13)$

10,00

8,57

2,85

1,42

4,28

5,70

4,28

2,85

2,84

Fonte: Trabalho de Campo Fev - Jun 2009.

Organização: Natália Freire Bellentani

Entre os motivos apresentados como mais comuns que provocam a morte em todas as áreas pesquisadas foram as doenças cardiovasculares - como infarto, angina, insuficiência cardíaca e problemas nas válvulas do coração (ass. "Mário Lago": 30,95\%; ass. "Sepé Tiarajú": $25 \%$ e área periférica: 10\%). Em seguida tivemos relatos sobre mortes provocadas por câncer ou derrame. Além desses fatores, a doença de chagas e as doenças pulmonares também aparecem em todas as áreas configurando o motivo da morte dos pais dos entrevistados, sejam homens, mulheres ou os dois, no caso da perda de ambos.

No que diz respeito à freqüência ao médico no Assentamento "Mário Lago" foi de três a cinco vezes por ano enquanto que as famílias entrevistadas no "Sepé Tiarajú" apresentaram uma freqüência, em média, mensal ao médico, isto significa dizer que ao menos uma vez por mês visitaram, seja o posto de saúde ou o hospital. 
$\mathrm{Na}$ área de periferia urbana esta freqüência ficou em torno de três a cinco vezes por ano.

Os motivos apresentados, além das idas de rotina ao médico, foram: problemas cardíacos; pressão; diabetes; tireóide; dor de cabeça; dentista; derrame; hipertensão; ortopedia; gravidez; gripe e febre alta.

De forma comum os entrevistados descreveram em suas falas sobre as dificuldades encontradas para marcarem as consultas, para serem atendidos ou ainda para receber os medicamentos. No caso do assentamento "Mário Lago" e "Sepé Tiarajú" não há posto de saúde dentro das áreas, as famílias precisam se deslocar até a cidade para serem atendidas. Para os assentados do Mário Lago este deslocamento muitas vezes acontece por meio de caronas, a pé, carroça ou ainda com o ônibus que leva as crianças para escola. No "Sepé Tiarajú", aonde a distância até Serra Azul ou Serrana é maior, o deslocamento nunca é feito a pé, os assentados que não possuem o veículo para se locomover, ou vão de carona com o ônibus da escola, ou pegam o ônibus circular na rodovia e assim vão até aos municípios vizinhos, incluindo Ribeirão Preto. Não há registros sobre a presença de agentes de saúde que circulem ou façam visitação em ambos os assentamentos.

O grau de satisfação das pessoas entrevistadas com o atendimento recebido, tanto no campo como na cidade, esteve em torno de sete, em uma escala de variação entre zero e dez. Lembrando que os locais de atendimento são especialmente postos de saúde localizados nos bairros e prontos socorros, excepcionalmente são atendidos em hospitais.

No que tange as questões ligadas à alimentação pode-se aferir, tanto para o campo como para a cidade, que trata-se de uma grande preocupação para as 
famílias. Muitos entrevistados, na periferia, principalmente, referiam-se a este como um ponto de fundamental importância e diziam: "se não gastamos esse tanto com as despesas no mercado, temos que vender o almoço para comprar a janta”.

No entanto, nas áreas de assentamento estabelece-se uma relação diferente com a questão da alimentação, pois, ao produzirem seu próprio alimento, muitas vezes, os assentados valorizam de forma diferente o alimento que os nutre diariamente.

Existe uma "fartura" nessas áreas, uma "fartura" que vai além do sentido restrito da nutrição. Contudo, nota-se que na cidade, onde o alimento é apenas consumido, este processo acontece de forma um pouco distinta, não que as pessoas não dêem valor ao alimento, longe disso, mas o fato de ver as plantas serem cultivadas, crescerem e se desenvolverem, os animais serem alimentados e tornarem-se alimento, gera aos assentados uma perspectiva que não é contemplada na cidade, aonde foi possível observar que existe um determinado valor dado ao alimento, mas não ao processo que envolve esta produção. Como disse um dos assentados, no "Sepé Tiarajú”: "poder oferecer pra minha família um alimento limpo, sem veneno e cheio de vida, que eu plantei, vi cresce e colhi, é o que tem de melhor nessa vida".

Isto também implica na qualidade da alimentação, ou seja, a diversidade com que os sujeitos compõem suas refeições e também a ausência de substâncias químicas nocivas ao desenvolvimento. No caso dos assentamentos estudados as famílias não fazem o uso de agrotóxicos, defensivos agrícolas, fungicidas, herbicidas ou qualquer outro tipo de veneno em suas plantações, além de não plantarem sementes transgênicas, garantindo com isso um maior valor nutricional aos seus 
alimentos e uma vida mais saudável. Sendo assim, observa-se que no campo, mesmo com inúmeras adversidades enfrentadas para produzir, como por exemplo, escassez de água e ausência de auxilio técnico adequado e suficiente para a quantidade de famílias assentadas, as famílias possuem uma alimentação mais variada e mais saudável que aquela consumida na cidade, pois colhem seus frutos, suas verduras, alimentos que muitas vezes não chegam à mesa das famílias da periferia, inclusive e prioritariamente pelo alto valor com que são comercializados no comércio varejista que abastece os bairros.

Apesar disso, devido à proximidade entre a área periférica e o assentamento "Mario Lago" não é difícil verificar em determinados dias da semana, alguma carroça com um ou dois assentados fazendo o comércio de verduras no bairro, aproximando ainda mais a cidade do campo, neste caso, trazendo ainda para mais perto a reforma agrária da luta por melhores condições de vida na cidade.

Contudo, como mencionado anteriormente, não são poucas as dificuldades encontradas para produzir nas áreas de assentamento. No "Mário Lago", por exemplo, não há, ainda, água encanada, sendo que a cada 15 dias (em média, já chegando, em alguns momentos, a quase 25 dias) as famílias recebem em seus lotes a visita de um caminhão pipa da Prefeitura Municipal que enche alguns tambores com água, para o uso geral.

Em grande parte da área também não há rede de energia elétrica, algumas famílias possuem gerador, mas a maioria usa lampião. Também não há coleta de lixo, o que faz com que grande parte das famílias juntem o lixo e levem para cidade (deixando em um bairro próximo ao assentamento), ou ainda queimem uma parte 
não reciclável e re-utilize o orgânico como fonte de adubação ou alimentação de criações.

Pelo menos $50 \%$ das famílias entrevistadas juntam o lixo reciclado para venderem e outras doam àqueles que vendem, esta ação também pode ser verificada no Assentamento "Sepé Tiarajú", bem como nos bairros de periferia. Mesmo assim, as famílias reclamam bastante sobre os valores pagos pelos materiais recicláveis, sendo que estes estão cada vez mais baixos, não significando algum tipo de incremento concreto à composição da renda, seja no campo ou na cidade.

No assentamento "Sepé Tiarajú", a maior parte da área já conta com água encanada e rede de energia elétrica, quanto ao lixo, há coleta municipal regular, todavia como acontece no Assentamento "Mário Lago", pelo menos $90 \%$ das famílias separam/reciclam o lixo e re-utilizam especialmente o lixo orgânico para a nutrição das plantas e/ou animais.

Nos bairros da periferia têm-se água encanada, tratamento de esgoto e há coleta municipal de lixo regularmente. Todavia, de acordo com as respostas dadas às perguntas relacionadas a questões ambientais, ficou declarado que não existem trabalhos para o cuidado com o meio ambiente, sejam eles realizados pelas organizações não governamentais, movimentos sociais, escolas públicas, entre outros.

Destaca-se que nos assentamentos há uma maior articulação nesse sentido já que ambas as áreas possuem uma organização realizada pelo movimento social (MST) e com isso em reuniões freqüentes e também em cursos realizados pelo próprio movimento discute-se e incorpora-se no dia-a-dia práticas para minimizar as 
conseqüências deixadas em ambas as áreas pelo monocultivo da cana-de-açúcar, com isso todas $(100 \%)$ das famílias reconhecem a necessidade prioritária do cuidado com o meio ambiente, ainda que não participem da organização do movimento social, discutem em reuniões essa temática. Já na periferia não diagnosticamos nenhum tipo de organização social, religiosa ou política que trabalhe junto às famílias as questões ambientais, aliás não houve relatos por parte dos entrevistados acerca de qualquer tipo de articulação institucional a qual fizessem parte.

Nos assentamentos rurais foi possível identificar uma rotina que envolve questões relacionadas ao meio ambiente, sustentabilidade e qualidade de vida, os assentados relataram acerca da freqüência em reuniões para discutir, além de outros assuntos, o meio ambiente, e de acordo com os entrevistados tanto no assentamento "Mário Lago", como no "Sepé Tiarajú”, a cada quinze dias ou uma vez por mês em média, eles participam das reuniões organizadas pelo movimento social de luta pela terra e conversam sobre o tema, fazendo ou não parte do movimento. Além disso, o grau de importância dado por eles ao assunto é nove, em uma escala de zero a dez.

Além dessas questões ligadas à infra-estrutura das áreas e meio ambiente destaca-se como fundamental para uma discussão acerca da saúde/longevidade, as oportunidades de lazer que os sujeitos têm. Por meio de questões que envolvem o que eles consideram que há de bom para fazer onde moram e aquilo que julgam que há de belo para ver aonde vivem, bem como àquilo que ele gostariam de fazer/ver nesses locais, procuramos conhecer e caracterizar melhor as áreas estudadas. 
O conceito de lazer numa perspectiva de qualidade de vida, para Morais (1999) esta voltado para o desenvolvimento do sujeito como pessoa e membro de uma coletividade que, por meio das relações lúdicas, insiste na longa jornada rumo ao prazer. Neste sentido, para o autor, o lazer é não apenas concebido como um tempo de viver prazer fora das obrigações da vida, ou como um tempo de nos ocuparmos com atividades que divertem, mas sim, particularmente, que a alegria é possível como fruto da conquista da liberdade ao lidar com atitudes, espaços, tempos e atividades que busquem superar os muitos dilemas sociais colocados como desafios a essas conquistas.

Neste sentido, em uma escala de zero a dez, o grau de importância dado pelos entrevistados ao lazer foi sete, significando, nas palavras de um entrevistado da cidade, "que é bom ter lazer, pois é preciso descansar a cabeça e poder respirar um pouco mais aliviado da rotina que é tão pesada."

Na seqüência será possível verificar o que foi respondido pelos assentados e moradores dos bairros de periferia de Ribeirão Preto sobre o que há de bom para ser feito e visto e o que eles gostariam de fazer e ver em suas distintas localidades (Tabelas 17, 18, 19 e 20). 
Tabela 17: Freqüência das respostas dadas à pergunta: "O que há de bom para fazer onde mora?" nos assentamentos rurais e na área periférica urbana do município de Ribeirão Preto (\%).

\section{BOM PARA FAZER}

LOCAL

\begin{tabular}{|c|c|c|c|c|}
\hline & & & & \\
\hline & TRABALHO & $\begin{array}{l}\text { CONVIVÊNCIA } \\
\text { com } \\
\text { a comunidade }\end{array}$ & $\begin{array}{l}\text { APROVEITAR } \\
\text { as caracts do lugar }\end{array}$ & $\begin{array}{c}\text { NADA } \\
\text { de bom para } \\
\text { fazer }\end{array}$ \\
\hline Ass.Mario Lago & 78,6 & 26,1 & 21,4 & 9,52 \\
\hline Ass. Sepé Tiarajú & 87,5 & 0,00 & 0,00 & 12,5 \\
\hline Área periferia $(n-13)$ & 0,00 & 17,1 & 7,1 & 75,7 \\
\hline
\end{tabular}

Entre todas as categorias, nos assentamentos, "Sepé Tiarajú" (87,5\%) e "Mário Lago" (78,6\%) os entrevistados revelam que o que há de melhor para fazer onde moram é trabalhar, isto é, esses sujeitos apresentam uma relação que se estabelece na antítese da exploração à qual eram submetidos anteriormente. E, nesse momento, o trabalho assume uma dimensão que diz respeito à satisfação e à realização desses sujeitos, diferentemente das posições apontadas pelos moradores dos bairros de periferia.

No caso dos assentamentos as respostas que indicam o trabalho como o que há de melhor para ser feito relacionam a oportunidade de viver na roça; cuidar da natureza, criação e plantação como os principais elementos que determinam o trabalho como o melhor a ser feito onde se vive.

Pode-se verificar também que conversar com os vizinhos; reunir a comunidade, promover encontros, etc. é uma característica que define entre $17 \%$ 
dos entrevistados na periferia o que há de bom para ser feito onde moram, assim como no assentamento "Mário Lago", com 26\%. Aproveitar as características do lugar como por exemplo, a calmaria , o silêncio e o sossego são qualidades que para $7 \%$ dos entrevistados da periferia definem o que há de bom para ser feito onde moram bem como para assentamento "Mário Lago" com $21 \%$.

Todavia, como Santos (2007:116) afirma, a distribuição desigual dos equipamentos educacionais e de lazer é resultado da planificação urbana capitalista combinada com o processo especulativo do mercado.

Já não há dúvidas sobre a veracidade deste processo, tendo em vista que, nas áreas de periferia mais de $75 \%$ afirmaram que "não há nada de bom para se fazer onde moram", revelando um sincero "estranhamento" ao espaço em que vivem e uma séria demanda por equipamentos sociais públicos.

Tal situação remete imediatamente àquilo que os entrevistados gostariam de fazer onde moram. Salienta-se que, quando os entrevistados foram questionados sobre aquilo que "gostariam de fazer" onde moram, a grande maioria relacionou o "fazer" com aquilo que precisavam "ter" para realizar tais atividades, especialmente ítens relacionados à prática de esportes e ao lazer (centro de convivência; campo de futebol, malha, bocha; parquinho para as crianças), mas também ligados à saúde e educação (cursos profissionalizantes; escola; creche; posto de saúde; farmácia) além de melhorias na infraestrutura pública e particular (Tabela 18). 
Tabela 18: Freqüência das respostas dadas à pergunta: "O que gostaria de fazer onde mora?" nos assentamentos rurais e na área periférica urbana do município de Ribeirão Preto (\%).

\section{GOSTARIA DE FAZER}

\begin{tabular}{lcccc}
\cline { 2 - 4 } LOCAL & $\begin{array}{c}\text { PRATICAR } \\
\text { ESPORTES, } \\
\text { ACESSO AO } \\
\text { LAZER }\end{array}$ & $\begin{array}{c}\text { ESTUDAR E/OU } \\
\text { CUIDAR DA SAÚDE }\end{array}$ & $\begin{array}{c}\text { MELHORIAS } \\
\text { PARA O } \\
\text { BAIRRO OU } \\
\text { ASSENTAMENTO }\end{array}$ & $\begin{array}{c}\text { MELHORIAS PARA } \\
\text { CASA/FAMÍLIA }\end{array}$ \\
\cline { 2 - 5 } Ass. Mario Lago & 54,8 & 50,0 & 9,52 & 2,42 \\
\cline { 2 - 5 } Ass. Sepé Tiarajú & 25,0 & 25,0 & 0,00 & 50,0 \\
\cline { 2 - 5 } & 40,0 & 37,1 & 22,9 & 0,00 \\
\hline
\end{tabular}

Fonte: Trabalho de Campo Fev - Jun 2009.

Organização: Natália Freire Bellentani

Como afirma Meszáros (2006) nas condições atuais, do capitalismo, há uma sobreposição de todos os sentidos físicos e mentais "pelo simples estranhamento de todos esses sentidos pelo sentido do ter" (p. 266). Desta feita podemos verificar que na área de periferia as respostas estiveram ligadas de forma equilibrada entre a vontade que eles têm em ter acesso aos equipamentos de lazer (campo de futebol, malha, bocha, parquinho para as crianças, cursos profissionalizantes, templo religioso) para realizar atividades de convivência e esportivas (40\%) e também aos equipamentos educacionais e de saúde $(37,14 \%)$. Além, é claro, de respostas ligadas às questões de melhorias para o bairro, como mais e melhor segurança e transporte público. Revela-se aqui, o fato de que nesses bairros que compõem a área periférica estudada, o transporte público é fundamental para um grupo preponderante de moradores, sejam os trabalhadores, sejam os estudantes, pois, a ligação entre o par centro-periferia, na maior parte dos casos, é feita por meio do 
transporte público, que de acordo com os entrevistados, é insuficiente e tem um valor alto de tarifa ( $R \$ 2,30$ o bilhete simples e $R \$ 2,50$ o bilhete integrado).

No assentamento "Mário lago", 50\% dos entrevistados, em média, e no assentamento "Sepé Tiarajú" em torno de $25 \%$ dos entrevistados também disseram sentir falta de um centro de convivência, aonde possam praticar esportes, aprender com os cursos profissionalizantes, levar as crianças para brincar ou ainda participar de cultos religiosos. A necessidade de equipamentos públicos como creches, postos de saúde, escolas e, privados como farmácia, mercado também apareceram como demandas, tanto do campo como da cidade.

Devemos aqui reforçar que em função do gênero dos respondentes podemos diagnosticar a existência de diferentes tipos de necessidades a serem atendidas, já que entre os homens e as mulheres há demandas distintas, mesmo assim como pudemos observar anteriormente há um equilíbrio entre os respondentes sendo que na periferia esta relação de gênero ficou em torno de $48,5 \%$ homens e $51,4 \%$ mulheres, no Sepé Tiarajú 45,2\% homens e 54,7\% mulheres que responderam ao questionário e para o assentamento "Mário Lago" essa diferença foi um pouco maior sendo a percentagem de respondentes homens de $37,5 \%$ e mulheres $62,5 \%$. Sendo assim, buscamos não fragmentar esta avaliação já que para a perspectiva que consideramos para o desenvolvimento humano em distintos territórios, é uma perspectiva que contempla as diversidades e trabalha para além dos pressupostos do individuo e sim do coletivo.

Ressalta-se ainda que no campo, por se tratarem de áreas de reforma agrária ainda com muitas carências (urgentes) de infra-estrutura básica, a água encanada e energia elétrica também apareceram -como itens de melhoria para a casa e família- 
que as pessoas gostariam de fazer onde moram, reforçando o sentido de "ter" para "fazer".

\section{c) Belo para ver}

Cabral (1993) define a beleza de uma paisagem como "sendo resultante da ordem que se manifesta no equilíbrio ecológico dos diversos fatores que nela atuam e na sua adequação aos interesses do homem".

Nesta perspectiva, procurou-se apreender as respostas dos entrevistados. Sendo que, nas áreas de assentamentos rurais, a totalidade inquirida afirma que o que há de bom para ser visto onde moram é a natureza, especialmente pássaros, flores, árvores, florestas, o nascer e pôr do sol, o céu, estrelas, além é claro, de suas criações de pequenos animais e as plantações. Ligado a este ponto principal eles também sustentam que a acolhida que os moradores destas localidades dão a quem chega é uma coisa bonita de ser vista, bem com como a "simplicidade do povo", como eles mesmo disseram. (Foto 7; Tabela 19). 


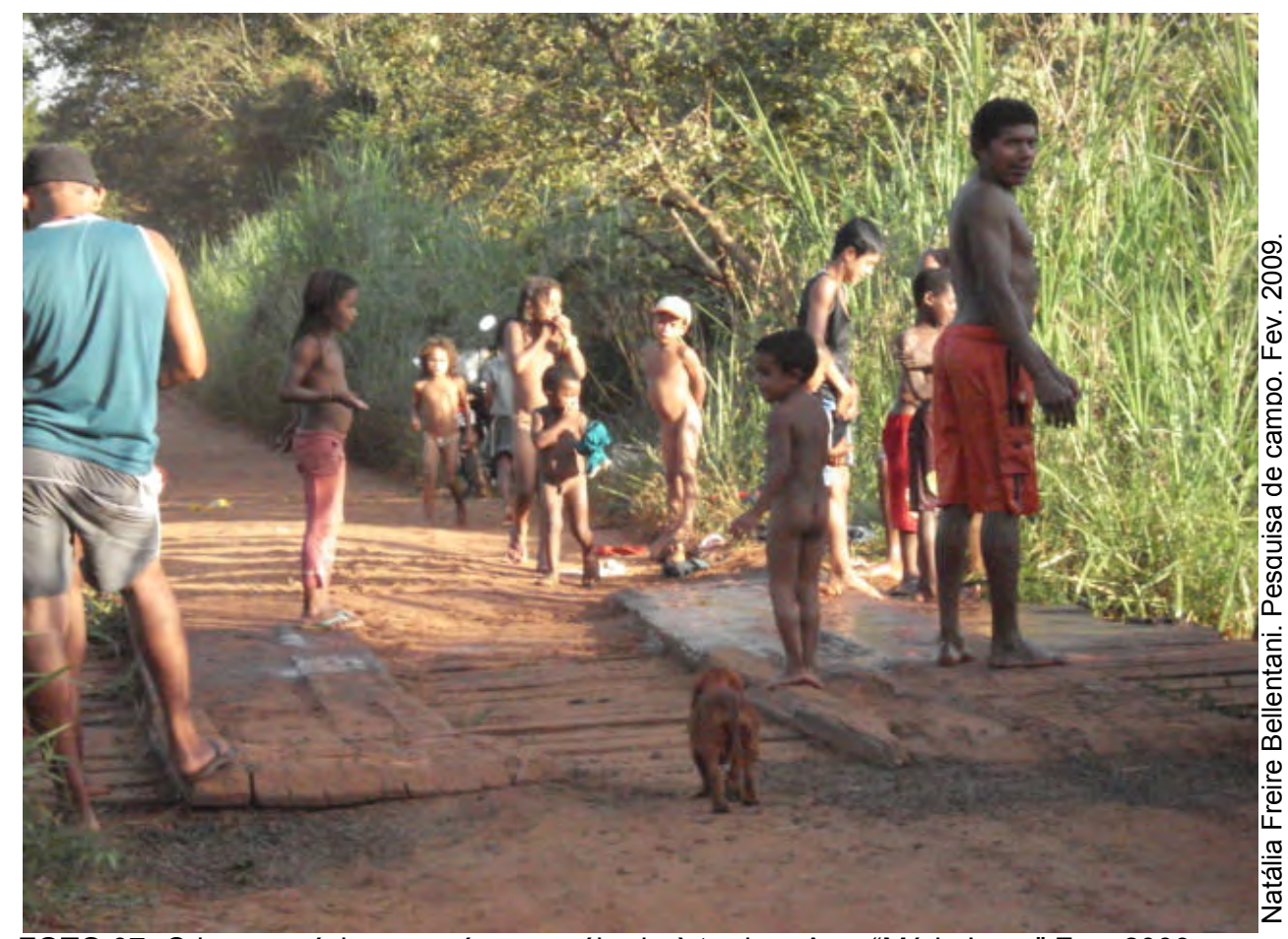

FOTO 07: O lazer, próximo ao córrego, sábado à tarde - Ass. “Mário Lago” Fev. 2009.

Tabela 19: Freqüência das respostas dadas à pergunta: "O que há de bom para ver onde mora?" nos assentamentos rurais e na área periférica urbana do município de Ribeirão Preto (\%).

\begin{tabular}{lcccc} 
& \multicolumn{4}{c}{ BELO PARA VER } \\
\cline { 2 - 5 } LOCAL & NATUREZA & COMUNIDADE & AVIÕES & $\begin{array}{c}\text { NADA } \\
\text { de bom para ver }\end{array}$ \\
\cline { 2 - 5 } & 100 & 14,28 & 0,00 & 0,00 \\
Ass. Mario Lago & 100 & 12,5 & 0,00 & 0,00 \\
Ass. Sepé Tiarajú & 0,00 & 5,71 & 4,28 & 91,4 \\
\cline { 2 - 5 } & Área periferia $(\mathrm{n}-13)$ & & &
\end{tabular}

Fonte: Trabalho de Campo Fev - Jun 2009.

Organização: Natália Freire Bellentani

Nota-se que na área periférica urbana, a grande maioria $(91,42 \%)$ diz não haver nada de bom para ser visto onde moram, mesmo assim uma pequena parcela dos entrevistados $(4,28 \%)$ declara que os aviões que circulam pelo bairro 
bem como o aeroporto, é algo agradável à vista, elemento totalmente estranho à sua interioridade, isto é, a materialidade da paisagem não permite a esses sujeitos que construam uma subjetividade própria de si.

O modo acolhedor que o povo tem de receber as pessoas que chegam e a forma simples de viver é algo que aparece como bonito para ser visto, tanto nos assentamentos ("Mário Lago" 14,28 \% e "Sepé Tiarajú 12,5\%), como na periferia de Ribeirão Preto $(5,71 \%)$.

Desta feita, avançamos com esta discussão, propondo que os respondentes dissessem sobre o que gostariam de ver na localidade onde moram, considerando as dimensões subjetivas e objetivas do sujeito, ou seja, aquelas ligadas ao desenvolvimento humano (Tabela 20).

Tabela 20: Freqüência das respostas dadas à pergunta: "O que gostaria de ver onde mora?" nos assentamentos rurais e na área periférica urbana do município de Ribeirão Preto (\%).

\section{GOSTARIA DE VER}

$\underline{\text { LOCAL }}$

\begin{tabular}{cccc}
\hline $\begin{array}{c}\text { EQUIPAMENTOS } \\
\text { PÚBLICOS }\end{array}$ & $\begin{array}{c}\text { CASA } \\
\text { PRÓPRIA }\end{array}$ & $\begin{array}{c}\text { ÁREAS } \\
\text { DE LAZER }\end{array}$ & $\begin{array}{c}\text { PRODUÇÃO } \\
\text { AGROECOLÓGICA }\end{array}$ \\
\hline 21,4 & 11,9 & 16,7 & 59,5 \\
12,5 & 37,5 & 0,00 & 75,0 \\
\hline 50,0 & 0,00 & 54,3 & 0,00 \\
\hline
\end{tabular}

Área periferia $(\mathrm{n}-13) \quad 50,0$

Organização: Natália Freire Bellentani

Durante o diálogo sobre o que gostariam de ver nas áreas onde moram, fazendo alusão a um futuro próximo, um grupo preponderante no campo ("Mário Lago" $59,75 \%$ \% e "Sepé Tiarajú $75 \%$ ) respondeu que ver a horta produzindo, o pomar formado, a criação se reproduzindo e ter água/luz em abundância para fazer 
tudo isso, ou seja, a produção agroecológica e os meios para produzir, seria o que há de mais belo para ser visto em suas áreas de moradia. Em relação às questões relacionadas à casa própria (reforma da casa; melhorar as condições da casa; construir a minha própria casa, etc.) nos assentamentos aparecem como algo que os entrevistados gostariam de ver, seja no "Mário Lago" 12\% ou no "Sepé Tiarajú" em torno de $37 \%$.

Já na área de periferia as respostas concentraram-se em torno dos equipamentos públicos e nesse sentido a vontade de "ver mais escola, postos de saúde, farmácias, mercados, creches, transporte melhor, praças, terrenos limpos e as crianças longe da violência", foram os exemplos mais marcantes relatados pelos moradores da área de periferia (50\%). Além disso, em torno de $54 \%$ dos respondentes da periferia disseram querer ver mais áreas de lazer para que as crianças tenham aonde brincar, para os jovens e adultos praticarem esportes e também para realizar cursos profissionalizantes para as mulheres.

$\mathrm{Na}$ foto abaixo podemos dizer que ainda que haja uma grande expectativa em torno daquilo que "gostariam de ver", todos, sem exceção, ainda que tenham receio de deixar as crianças pela rua (por conta da violência), gostam de vê-las brincando pelas calçadas e árvores da vizinhança (Foto 08). Há sempre um sinal de esperança nos olhos de cada um quando as crianças brincam e os fazem esquecer, ainda que por um rápido instante, da realidade muito difícil em que (sobre) vivem. 


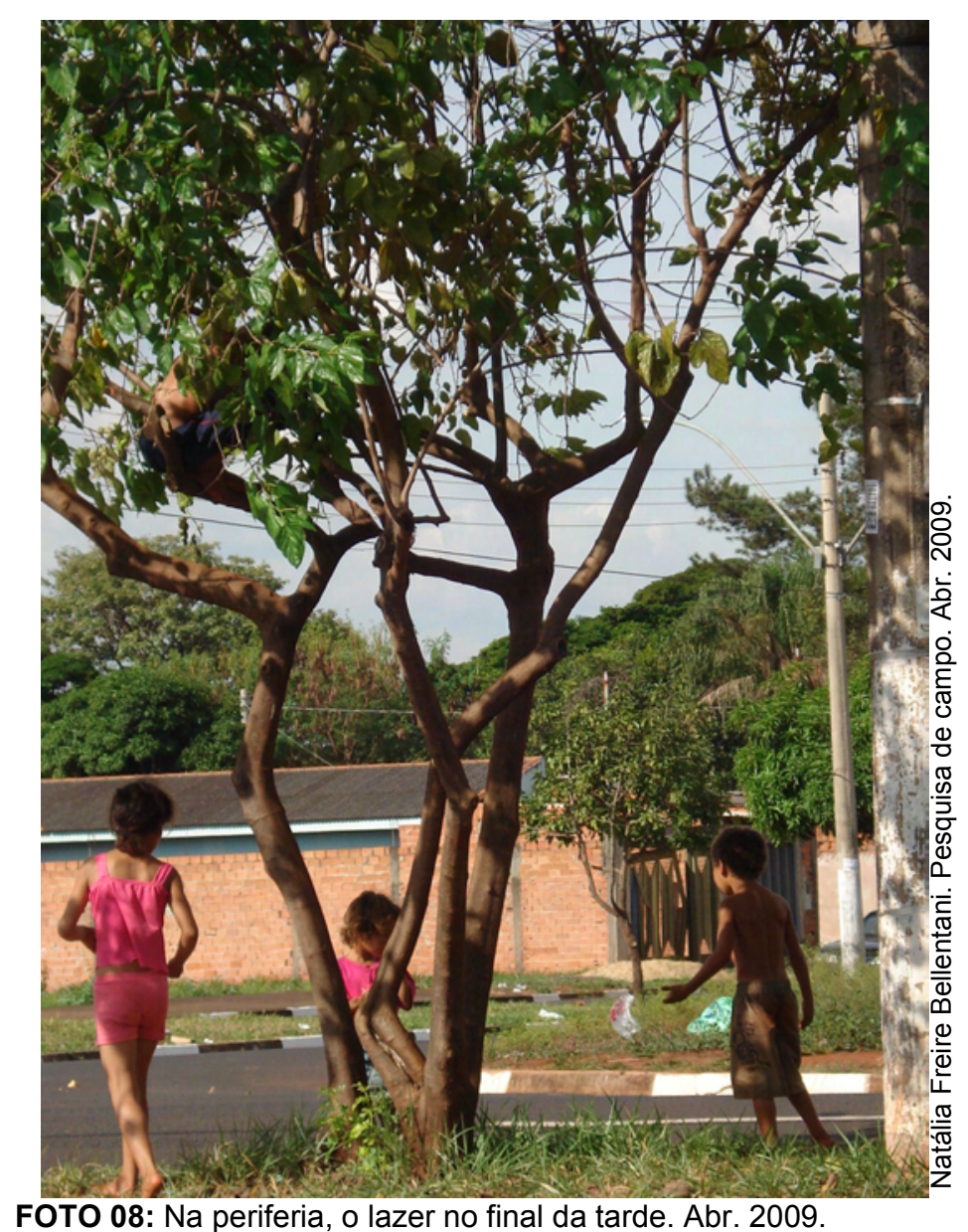

FOTO 08: Na periferia, o lazer no final da tarde. Abr. 2009.

Sendo assim, pudemos observar que do ponto de vista quantitativo as diferenças aparecem de forma bastante diminuta (IDH-Longevidade: Mário Lago: 0.660; Sepé Tiarajú: 0.633; Área periferia: 0.650), não revelando ponderações de fato significativas. O lazer, por exemplo, foi apontado tanto pelos assentados, como para os moradores das áreas de periferia urbana, como uma questão de fundamental importância para o aumento da expectativa de vida. Sendo que na periferia esse elemento qualitativo aparece vinculado à exterioridade do sujeito, marcando uma relação mais forte com o objeto do que com o próprio sujeito em seu processo de desenvolvimento. 
A dimensão saúde relaciona-se com diferentes matérias, inclusive quando os assentados se referiram àquilo que tinham de bom para fazer, afirmaram que era no trabalho que se realizavam, isto é, dimensões que poderiam ser tratadas de formas distintas ou fragmentadas, estão atreladas, revelando que algumas diferenças só serão compreendidas do ponto de vista qualitativo.

Neste sentido, cabe afirmar que um repensar mais vasto sobre esta aferição que é dada à saúde pelo IDH torna-se indispensável, pois a realização do sujeito e sua expectativa de vida estão intensamente ligadas aos componentes qualitativos que são anulados do ponto de vista matemático.

\subsubsection{A dimensão renda nos assentamentos e na cidade}

A respeito da dimensão renda, terceiro e último indicador que compõe o Índice de Desenvolvimento Humano, destaca-se, a princípio, as respostas dos entrevistados acerca da importância da renda e do trabalho, bem como o cálculo oficial do IDH-Renda. Em seguida, será apresentada a composição dos gastos e rendimentos das famílias dos assentamentos e da periferia na cidade de Ribeirão Preto além de uma discussão sobre os rendimentos não-monetários (que são gerados, especialmente, por meio da produção de bens agrícolas nas áreas de reforma agrária). E por fim estende-se a discussão relatando uma questão apontada pelos entrevistados como central para a composição da renda, que trata dos benefícios e aposentadorias recebidos pelos mesmos. 


\section{a) Importância da renda}

A renda e o trabalho são uma dimensão apontada pelos respondentes desta pesquisa como muito relevante para o desenvolvimento humano. Nos assentamentos rurais e na área periférica, em uma escala de zero a dez, o grau de importância dado sobre a renda e o trabalho, foi dez, pelos respondentes.

Os entrevistados justificaram esta relevância dada ao trabalho e a renda dizendo, entre outras coisas, que: "o trabalho e a renda que é gerada, é o que nos mantém vivos, o trabalho é sinônimo da nossa vida". Um entrevistado do assentamento "Mário Lago" salientou que: "receber a renda é como ver crescer e poder colher aquilo que plantei”. Afirmação que demonstra o valor aferido, no âmbito concreto e abstrato, ao trabalho, cuja satisfação evidencia a prioridade dada a essa categoria pelos assentados.

Na periferia, mais de $40 \%$ dos entrevistados disseram que "a renda melhora as condições de vida e dá oportunidade de atenderem as necessidades da família" (Tabela 21). 
Tabela 21: Freqüência das respostas dadas à pergunta: "Por que a renda e o trabalho são importantes para o seu desenvolvimento?" nos assentamentos rurais e na área periférica urbana do município de Ribeirão Preto (\%).

\begin{tabular}{|c|c|c|c|c|}
\hline LOCAL & $\begin{array}{l}\text { Melhora nossas } \\
\text { condições de vida } \\
\text { e atende as } \\
\text { necessidades da família. }\end{array}$ & $\begin{array}{l}\text { Para nos } \\
\text { mantermos vivos; } \\
\text { O trabalho é a } \\
\text { vida da gente }\end{array}$ & $\begin{array}{l}\text { Importante } \\
\text { assim como a } \\
\text { saúde e a } \\
\text { educação }\end{array}$ & $\begin{array}{l}\text { É importante, } \\
\text { mas não é o } \\
\text { primordial. }\end{array}$ \\
\hline
\end{tabular}

Ass. Mario Lago

Ass. Sepé Tiarajú

Área periferia $(\mathrm{n}-13)$

Fonte: Trabalho de Campo Fev - Jun 2009.

Organização: Natália Freire Bellentani
21,4

37,5
61,9

62,5

34,3
9,52

0,00
0,00

7,14

5,71

Por meio das respostas dadas pelos entrevistados no que tange à renda e o trabalho fica claro que os mesmos os consideram como mecanismos fundamentais para o desenvolvimento humano. Ainda assim, registra-se que nas áreas de reforma agrária, assentamentos rurais, o sentido do trabalho foi apontado com uma importância relevante para a realização dos sujeitos, e esta dimensão se conectou diretamente à questão da longevidade, traduzindo o trabalho para as pessoas com mais de 60 anos, por exemplo, como uma condição fundamental para reprodução social.

O valor dado ao trabalho pelos assentados é distinto daquele aferido pelos respondentes da cidade. Na periferia, o trabalho está mais atrelado às questões materiais e menos ao valor que se tem realizando as atividades.

Contudo, antes de colocar em oposição trabalhadores do campo e trabalhadores da cidade e com isso ampliar a dicotomia entre campo-cidade, reconhece-se que a articulação realizada pelo movimento social no campo é determinante para que haja esse tipo de organização social e reconhecimento do 
trabalho enquanto um fator fundamental para a possibilidade de transformação social e desenvolvimento humano.

\section{b) Cálculo do IDH-Renda}

Para a avaliação da dimensão renda, de acordo com o PNUD (2008), deve-se utilizar o indicador renda per capita média obtido a partir da fórmula demonstrada a seguir: IDH-R= (log de renda média municipal per capita - log do valor de referência mínimo) / (log do valor de referência máximo - log do valor de referência mínimo), onde os limites inferior e superior são equivalentes a $R \$ 3,90$ e $R \$ 1560,17$, respectivamente.

Estes limites correspondem aos valores anuais de PIB per capita de US\$100 ppp e US\$ 40.000, segundo o critério de Paridade do Poder de Compra, utilizados pelo PNUD no cálculo do IDH-Renda dos países, convertidos a valores de renda per capita mensal em reais através de sua multiplicacão pelo fator (R\$297/US\$7625 ppp), que é a relação entre a renda per capita média mensal (em reais) e o PIB per capita anual (em dólares ppp) do Brasil em 2000. (PNUD, 2008)

Tabela 22: Cálculo do IDH-Renda baseado na renda média anual per capita $(\mathrm{R} \$)$ nos Assentamentos Rurais e Área Periférica do Município de Ribeirão Preto.

\begin{tabular}{lccc}
\hline LOCAL & $\begin{array}{c}\text { Renda Média } \\
\text { Anual Per Capita } \\
\text { (R\$) }\end{array}$ & $\begin{array}{c}\text { Renda Média } \\
\text { Mensal Per Capita } \\
\text { (R\$) }\end{array}$ & $\begin{array}{c}\text { IDH-Renda } \\
\text { (logRM*-log3.9) / (log1560.17-log3.9) }\end{array}$ \\
\cline { 2 - 4 } Ass.Mario Lago & $4.826,76$ & 402,23 & $\mathbf{0 , 7 7 3}$ \\
$\begin{array}{l}\text { Ass. Sepé } \\
\text { Tiarajú }\end{array}$ & $3.336,48$ & 278,04 & $\mathbf{0 , 7 1 2}$ \\
$\begin{array}{l}\text { Área periferia (n- } \\
\text { 13) }\end{array}$ & $4.205,17$ & 350,43 & $\mathbf{0 , 7 5 0}$ \\
$\begin{array}{l}\text { RM*: renda média mensal per capita (renda monetária e não monetária) } \\
\text { Fonte: Trabalho de Campo Fev - Jun 2009. } \\
\text { Organização: Natália Freire Bellentani }\end{array}$
\end{tabular}


Os valores do indicador de renda das áreas variou entre 0,773 para o assentamento "Mário Lago", 0,750 para os bairros de periferia e para o assentamento "Sepé Tiarajú" esse índice foi de 0,712 , todos considerados médios. Lembrando que em 2000 o cálculo do IDH-Renda para município de Ribeirão Preto, foi de 0,823 , índice considerado alto e o município do estado de São Paulo que apresentou menor índice foi Itapecerica da Serra, com IDH-R igual a 0,554 (Tabela 23) .

Tabela 23: Cálculo -referente ao ano de 2000- do IDH-Renda do município de Ribeirão Preto e municípios com maior e menor índice no estado de São Paulo (IPEA, 2000).

\begin{tabular}{cccc} 
& Ribeirão Preto & Município maior IDH-R & Município menor IDH-R \\
\cline { 2 - 3 } IDH - Renda & $\mathbf{0 , 8 2 3}$ & 0,918 & 0,554 \\
& & (Águas Sta Bárbara) & (Itapecerica da Serra)
\end{tabular}

Fonte: Instituto de Pesquisa Econômica Aplicada (IPEA) 2000.

Organização: Natália Freire Bellentani

Da mesma forma que quando trabalhamos com as dimensões educação e saúde, a questão da renda e do trabalho também se comportam como uma matéria bastante atrelada aos elementos qualitativos incluídos nesta dimensão.

Para exemplificar, veremos que nas áreas de assentamento de reforma agrária, atualmente, as famílias respondem a uma menor dependência de políticas assistenciais, enquanto que na periferia $12 \%$ dos entrevistados dependem exclusivamente desta renda para viver. Pode-se também inferir, nesta perspectiva qualitativa, o quanto a dimensão do trabalho dentro de uma área de assentamento é distinta daquela apreendida nas áreas de periferia e assim, vale a pena lembrar que a renda no campo tem um componente não-monetário, que diz respeito ao auto- 
consumo e que está diretamente vinculado à reprodução social. Mesmo assim é muito importante ressaltar a dependência que as famílias tanto nos ao benefícios e aposentadorias. Sendo que nos assentamentos este fato deve ser refletido ainda com mais atenção, tendo em vista que um projeto de reforma agrária que aponta para novas perspectivas da melhoria das condições de vida destas populações e destaca a autonomia e alteridade como elementos fundamentais na construção cidadã, ainda mantém as pessoas sob uma condição de extrema carência, a ponto de ser necessário receber determinados tipos de auxilio para a mantença da vida. Certamente faz-se necessário uma reavaliação por parte do movimento social do tipo de assentamento que tem proposto -como é o caso da comuna da terra- e por parte do Estado, fazer de fato a reforma agrária e não uma simplicíssima política de assentamento que não promove a transformação social, afinal para além da pobreza material, o foco deve estar na trajetória da vida futura dessas pessoas.

\section{c) Renda / despesas}

Na área periférica urbana, a composição da renda se dá, especialmente, pelo recebimento de salários mínimos, seja pelo trabalho formal ou informal, além das aposentadorias, caracterizando desta forma a base da renda na cidade. Nos assentamentos rurais a base da renda está vinculada a produção agropecuária, aos benefícios sociais e salários mínimos recebidos por meio de algumas atividades que são realizadas na cidade.

Nos assentamentos rurais "Mário Lago" e "Sepé Tiarajú", a pesquisa revela que a renda média anual per capita esteve em torno de $\mathrm{R} \$ 4.826,76$ e $\mathrm{R} \$ 3.336,48$, 
respectivamente; enquanto que na área periférica urbana, a renda média anual per capita apresentou-se com o valor de $\mathrm{R} \$ 4.205,17$.

As despesas nas áreas de assentamentos rurais estão ligadas, especialmente, aos gastos com a produção (horas máquina, sementes, etc.), supermercado, transporte, telefone, água, luz, ajuda aos familiares, entre outros. $\mathrm{Na}$ periferia basicamente são os mesmo gastos, excluindo os gastos com produção e incluindo as despesas com aluguel (Tabela 24).

Tabela 24: Cálculo das despesas anuais/pessoa e \% das despesas na renda média anual/pessoa, nos assentamentos rurais e na área periférica urbana do município de Ribeirão Preto.

\begin{tabular}{lccc}
\hline LOCAL & $\begin{array}{c}\text { DESPESAS/ } \\
\text { ANO/ PESSOA } \\
\text { (R\$) }\end{array}$ & $\begin{array}{c}\text { RENDA MÉDIA/ } \\
\text { ANO/ PESSOA } \\
\text { (R\$) }\end{array}$ & $\begin{array}{c}\text { DESPESAS NA RENDA } \\
\text { (\%) }\end{array}$ \\
\cline { 2 - 4 } Ass. Mario Lago & 2337,02 & $4.826,76$ & 48,41 \\
Ass. Sepé Tiarajú & 1457,13 & $3.336,48$ & 43,67 \\
Área periferia (n-13) & 1974,59 & $4.205,17$ & 46,95 \\
\hline
\end{tabular}

Fonte: Trabalho de Campo Fev - Jun 2009.

Organização: Natália Freire Bellentani

Nos bairros investigados da periferia de Ribeirão Preto, há em 13\% das famílias entrevistadas, membros que também trabalham no setor informal, estes se dividem entre essas atividades e o trabalho formal, além de desempenharem, principalmente, no caso das mulheres, os afazeres domésticos, concomitantemente junto às demais atividades.

Como podemos verificar nas fotos abaixo muitas jornadas de trabalho realizam-se no cotidiano dessas famílias, configurando dessa forma um território de trabalhadores no município de Ribeirão Preto. Na primeira, observaremos uma senhora que trabalha como cozinheira para uma empresa de marmitas, no bairro Jd. 
Aeroporto, além disso, vende salgados na rua e, ainda cuida dos netos para o filho durante as folgas do serviço. Na segunda foto, é possível verificar na fachada da casa os anúncios de trabalhos, que compõem a renda de uma das famílias entrevistadas no bairro Jd Salgado Filho 1 (Foto 09 e 10).

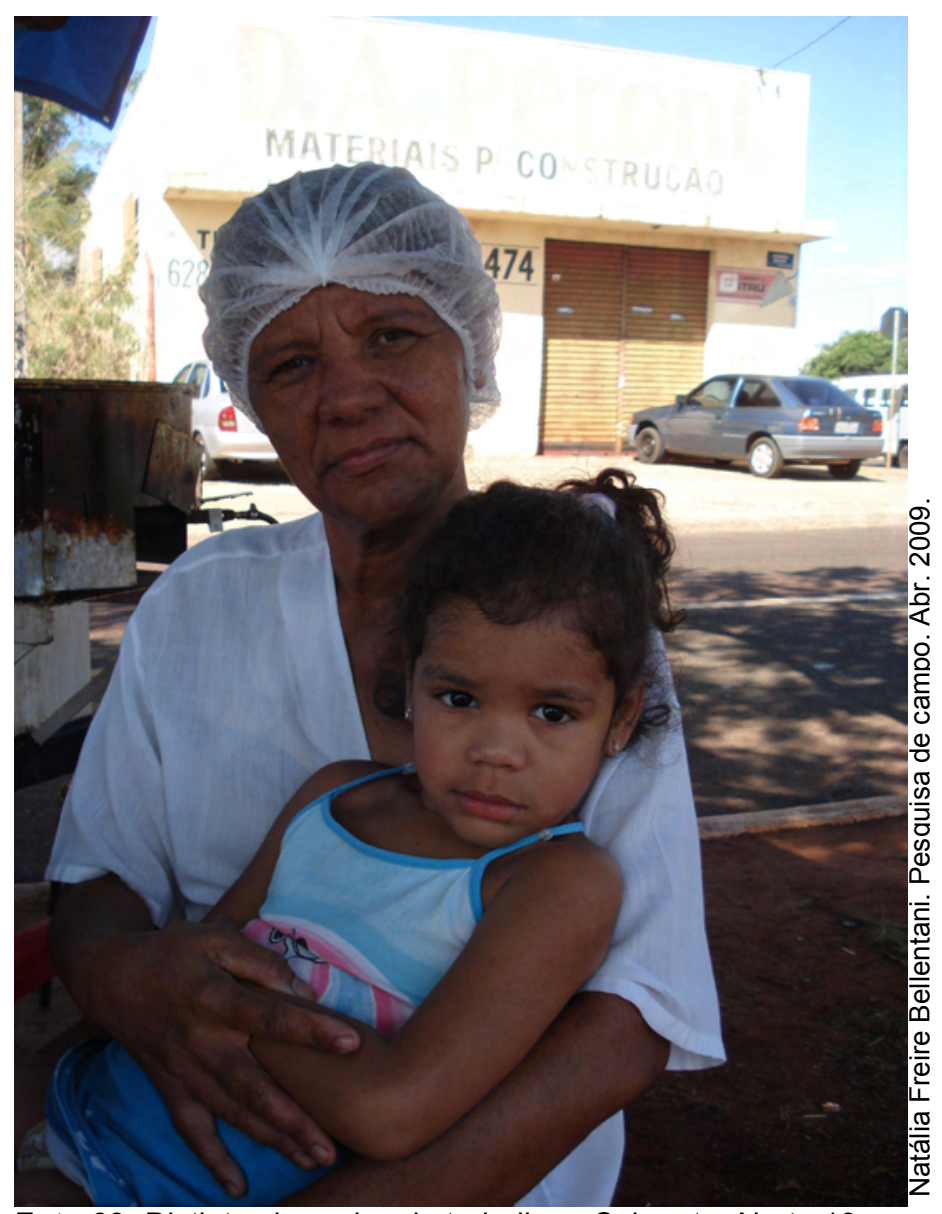

Foto 09: Distintas jornadas de trabalho - Sub-setor Norte 13 


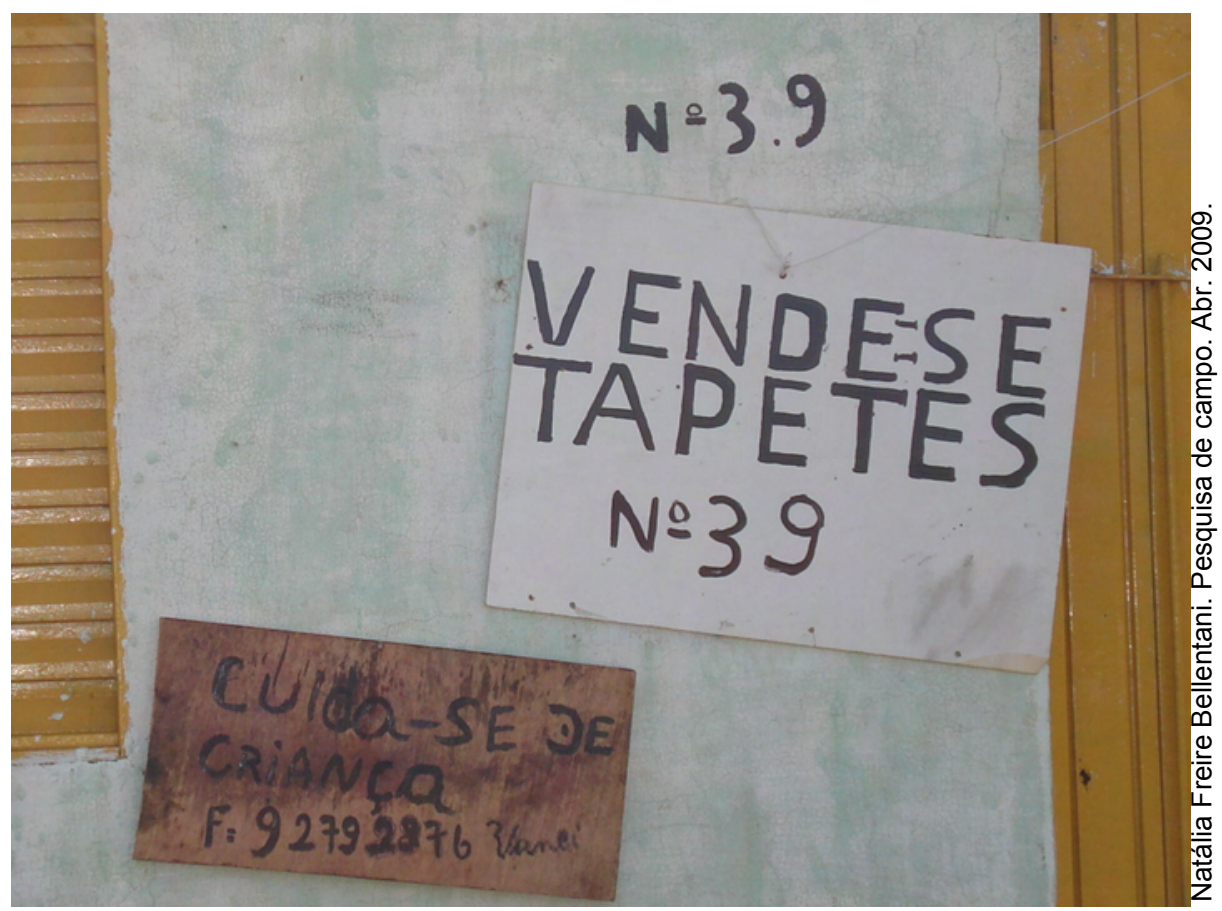

FOTO 10: Anúncios de "muito trabalho". Sub-setor Norte 13 - Rib. Preto

É muito interessante também destacar algumas particularidades na composição da renda no campo, ou seja, salientar as outras atividades desenvolvidas pelos membros da família assentada e que compõem a renda familiar, além da atividade agropecuária.

A seguir apresenta-se na Tabela 25 a percentagem das famílias que vivem exclusiva/e com renda da produção agropecuária; lembrando que $75 \%$ das famílias entrevistadas no assentamento "Sepé Tiarajú" e 64\% no assentamento "Mário lago", estão vinculadas ao Programa de Aquisição de Alimentos - PAA e fazem suas vendas exclusivamente pelo PAA. Deste total $75 \%$ dos entrevistados no assentamento "Sepé Tiarajú" e 55\% no assentamento "Mário lago" fazem suas vendas de forma direta (atacado ou varejo) e também pelo programa de forma combinada; por fim, $25 \%$ no assentamento "Sepé Tiarajú" e $30 \%$ no assentamento "Mário lago" fazem suas vendas apenas de forma direta e não fazem parte do PAA. 
De acordo com a Companhia Nacional de Abastecimento (CONAB), o Programa de Aquisição de Alimentos - PAA foi Instituído pelo Art. 19 da Lei nº10. 696, de 02 de julho de 2003, e regulamentado pelo Decreto $n^{\circ} 6.447$, de 07 de maio de 2008 e tem como finalidade precípua o apoio aos agricultores familiares, por meio da aquisição de alimentos de sua produção, com dispensa de licitação.

Medeiros (1994) destaca que a política pública de reforma agrária neste processo deixa de ter um caráter exclusivo de distribuição de terras e passa a ter uma perspectiva de desenvolvimento com reflexos diretos no campo e na cidade. Tal perspectiva se refere à produção alimentar, à ocupação no campo, à preservação ambiental e à diversidade técnica e produtiva. Garantindo assim modos diferenciados de produção e reprodução humana. (MEDEIROS, 1994).

Daqueles que não vivem exclusivamente da produção do campo, as outras atividades estão relacionadas a serviços de motorista, funilaria, pedreiro, fábrica, faxineira, colheita de laranja, restaurante, ajudante em mercado ou mercearia ou auxiliar de serviços gerais. Além disso, a renda também apresenta um componente que diz respeito às aposentadorias e benefícios, tal como bolsa família.

Deve-se ressaltar que as áreas de assentamentos estudadas possuem área média dos lotes individuais variando entre 1,5 ha para o assentamento "Mário Lago" e 3,5 para o assentamento "Sepé Tiarajú", como ressaltamos anteriormente, o que em termos de produção, não é extremamente significativo; embora difícil para conquistar a reforma agrária em Ribeirão Preto, acontece de forma bastante incipiente. E provoca conflitos entre os diferente grupos que ocupam as áreas, como é o caso do assentamento "Mário Lago", que conta com três diferentes movimentos sociais e disputam as melhores faixas de terra e áreas aonde o acesso à água seja 
facilitado. Esses conflitos implicam na formação de um território que dispõe de características ímpares que ratificam os avanços e retrocessos na reprodução social dos sujeitos e afetam com isso seu desenvolvimento humano.

Desta feita, os membros da família justificam-se sobre o fato de buscarem alternativas para a composição da renda, suscitando o fato de que não são todos os membros que se ausentam, sempre um fica responsável pela produção, o que pode ser demonstrado pela questão da renda "não-monetária", ou seja, aquilo que produzem e não precisam comprar, especialmente produtos de origem animal e vegetal. Além, é claro, de evitar o absenteísmo, acontecimento muito comum na área rural de Ribeirão Preto, assim como em todo estado de São Paulo, provocado nos últimos anos, principalmente, pelo avanço do setor sucroalcooleiro, que tem como prática habitual o arrendamento de terras e cultivo da monocultura da canade-açúcar, fatores que provocam uma grave conseqüência no que diz respeito à permanência das famílias no campo.

Tabela 25: Famílias que vivem exclusivamente com a renda da produção agropecuária nos assentamentos rurais* (\%).

LOCAL

Famílias que vivem exclusivamente com a renda produção agropecuária (\%)

Ass. Mario Lago

21,4

Ass. Sepé Tiarajú

25,0

\footnotetext{
* Na cidade não há registro de famílias que vivam exclusivamente com renda de produção agropecuária. Fonte: Trabalho de Campo Fev - Jun 2009.

Organização: Natália Freire Bellentani
} 


\section{d) Renda não-monetária}

Embora a variável renda seja uma dimensão de difícil apreensão, considerando desde a coleta dos dados até os cálculos e discussão, é fundamental fazê-lo, tendo em vista que este conceito de renda como afirma Santos (2005) normalmente é orientado por um enfoque econômico centrado, exclusivamente, nas relações monetárias insumos-produto e voltados para oportunidades de mercado. Contudo, quando trabalhado em uma perspectiva menos fragmentada e reducionista pode-se incorporar a este conceito como Leite (2003) salienta, os rendimentos nãomonetários (auto-consumo) que são gerados por meio da produção de bens agrícolas, seguidos da produção pecuária. O auto-consumo confere uma importante complementação nos rendimentos monetários, tendo uma importante participação na composição dos rendimentos totais das famílias. (LEITE, 2003).

Neste aspecto, em que pese se tratar comumente de renda, os dados para os assentamentos devem ser considerados como receita agropecuária bruta. A formação de dados de renda em áreas rurais é de difícil apreensão e se necessita de estudos mais detalhados que possam demonstrar os custos efetivos a fim de indicar uma renda total ou mesmo renda monetária líquida média. No caso de assentamentos rurais, a receita agropecuária bruta constitui-se em um indicador médio de renda, uma vez que o consumo intermediário é extremamente reduzido o que garante, este dado, representar significativamente as condições sociais locais. (BELLENTANI; SOUZA, 2006).

Nos assentamentos pesquisados, conjuntamente ao consumo dos produtos agrícolas, tais como: abóbora, abobrinha, berinjela, tomate, pimenta, mandioca, 
milho verde, caxi, banana, mamão, maracujá, pimenta, manga, tangerina, feijão e verduras, realiza-se o abate de um ou dois frangos por mês, ou por semana, bem como de um porco por mês, ou a cada dois, três ou seis meses, representando com isso a formação de uma renda "não-monetária" (auto-consumo e autoabastecimento) das famílias.

Quando calculamos o IDH relativo à renda, retirando dos rendimentos mensais a renda de auto-consumo (não-monetária), identificamos valores ainda menores para o IDH-Renda nos assentamentos. Ainda que considerados médios no aspecto quantitativo, sob a ótica qualitativa, essa variação dos valores revela uma profunda diferença vivida no dia-a-dia dos assentados, que consomem aquilo que cultivam e garantem a autonomia no trabalho nessas áreas de reforma agrária. (Tabela 26 e 27)

Garcia Jr. (1983 e 1994) destaca que a inclusão dessa noção do autoconsumo é vital para a compreensão das formas e situações em que se dá a reprodução da agricultura familiar.

Tabela 26: Valores da renda média anual/pessoa, renda "não-monetária" anual/pessoa e \% renda não monetária na renda média anual/pessoa nos assentamentos rurais de Ribeirão Preto.

\section{LOCAL}

Renda média anual/pessoa

(R\$)

A $4.826,76$

$3.336,48$
Renda não monetária Renda não monetária Participação da renda anual*/pessoa

(R\$)

B

C

(R\$) média anual/pessoa (\%)

\begin{tabular}{|c|c|c|c|c|}
\hline Ass.Mario Lago & $4.826,76$ & 469,01 & 39,08 & 9.71 \\
\hline $\begin{array}{l}\text { Ass. Sepé } \\
\text { Tiarajú }\end{array}$ & $3.336,48$ & 856,50 & 71,37 & 25.67 \\
\hline
\end{tabular}


Tabela 27: Cálculo do IDH-Renda baseado na renda média anual per capita $(R \$)$, desconsiderando a renda não monetária nos Assentamentos Rurais e Área Periférica do Município de Ribeirão Preto.

\begin{tabular}{|c|c|c|c|c|}
\hline LOCAL & $\begin{array}{l}\text { Renda Média } \\
\text { Mensal Per Capita } \\
\text { (R\$) }\end{array}$ & $\begin{array}{c}\begin{array}{c}\text { Renda não } \\
\text { monetária } \\
\text { mensal//pessoa } \\
(\mathrm{R} \$)\end{array} \\
\end{array}$ & $\begin{array}{c}\text { IDH-Renda } \\
\left(\log M^{*}-\log 3.9\right) / \\
(\log 1560.17-\log 3.9)\end{array}$ & $\begin{array}{c}\text { IDH-Renda } \\
\left(\log R M^{* *}-\log 3.9\right) / \\
(\log 1560.17-\log 3.9)\end{array}$ \\
\hline Ass.Mario Lago & 402,23 & 39,08 & 0,773 & 0,757 \\
\hline Ass. Sepé Tiarajú & 278,04 & 71,37 & 0,712 & 0,663 \\
\hline
\end{tabular}

$\mathrm{RM}^{*}$ : renda média mensal per capita (renda monetária + não monetária)

$\mathrm{RM}^{\star *}$ : renda média mensal per capita (renda monetária - não monetária)

Fonte: Trabalho de Campo Fev - Jun 2009.

Organização: Natália Freire Bellentani

Como pudemos identificar no assentamento "Sepé Tiarajú" cerca de $25 \%$ da renda média anual das famílias entrevistadas é composta pelos rendimentos não monetários e no caso do assentamento "Mário Lago" esse valor é de 9,7\%. As diferenças (mais significativas) que configuram a distância entre esses valores de cada área estão ligadas ao tempo de formação de cada assentamento e mais uma vez a questão do tamanho de cada lote, sendo que no "Sepé Tiarajú" os lotes tem em média 3,5 ha e no "Mário Lago" este número em média é de 1,5 ha.

São valores relativamente baixos, considerando que estes rendimentos poderiam (se houvesse uma política efetiva de reforma agrária) configurar a maior parte da renda desses trabalhadores.

Contudo, percebe-se a tentativa e a realização de uma alternativa à realidade contemporânea, onde o individualismo, a violência e a miséria são paulatinamente transformados em solidariedade, abundância e autonomia, re-afirmando com isso um compromisso de manter a terra em condições adequadas para que outras gerações possam nela trabalhar e dela retirarem o sustento. (Foto 11 e 12). 


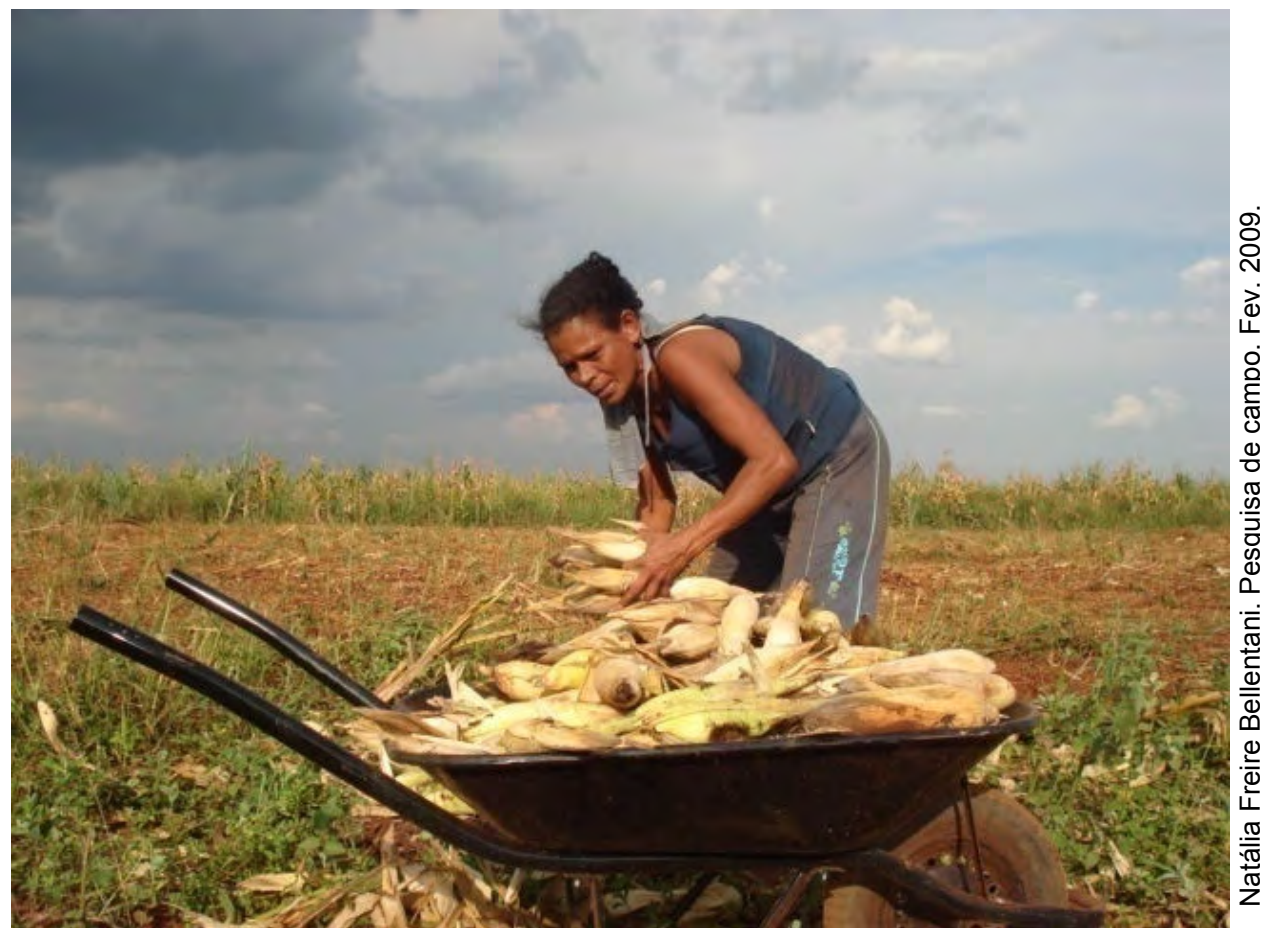

FOTO 11: Assentada recolhendo o milho da colheita (Ass. "Mario Lago")

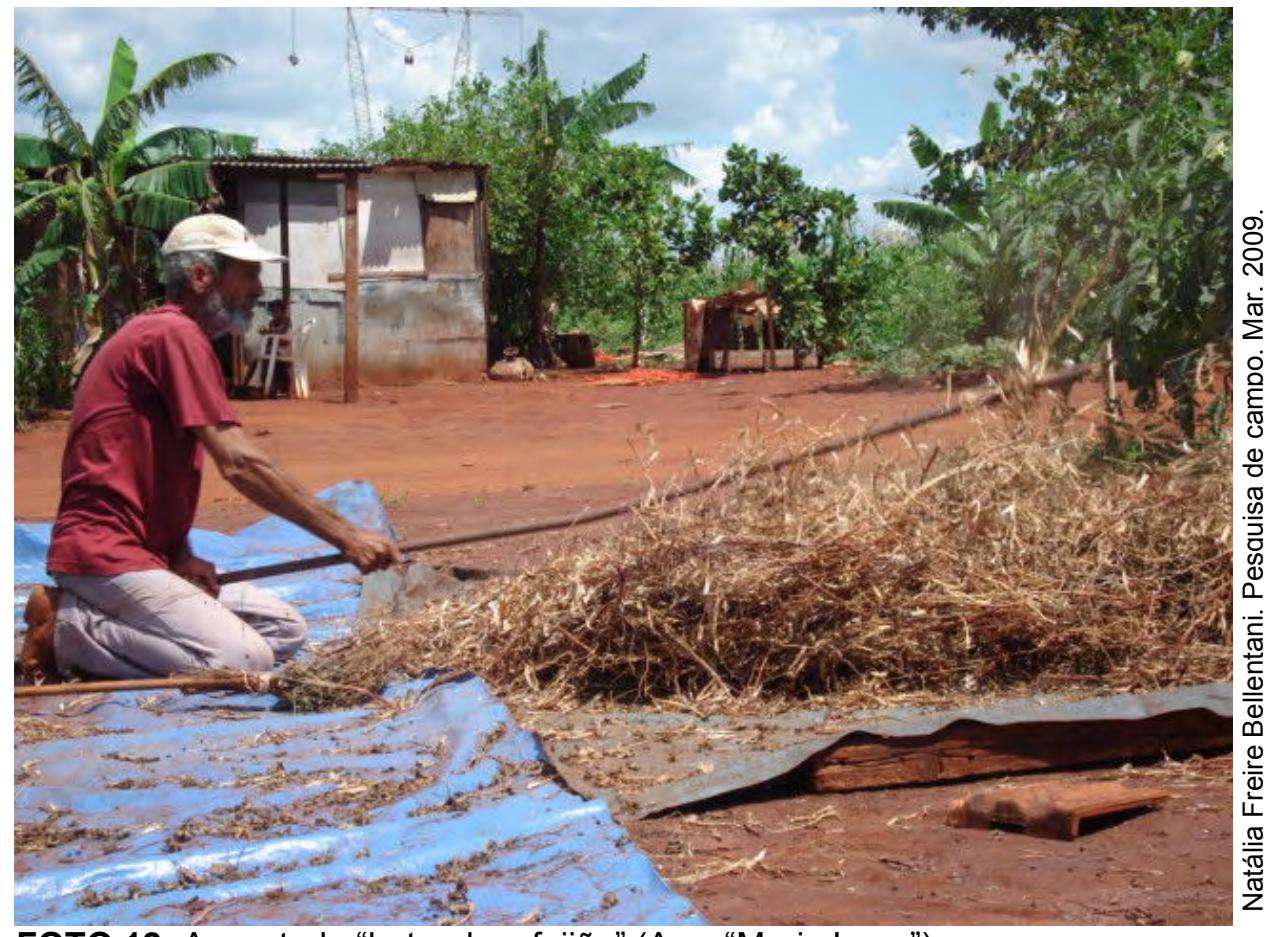

FOTO 12: Assentado "batendo o feijão" (Ass. "Mario Lago") 


\section{d) Aposentadorias e auxílios}

Como Hoffmann (2009) declara, o rendimento de aposentadorias e pensões é uma parcela importante dos rendimentos declarados no Brasil, tendo aumentado de 15,2\% em 1997 para 18,5\% em 2001 e 19,8\% em 2003 e 2005. Na Pesquisa Nacional por Amostra de Domicílios (PNAD) de 2007, as aposentadorias e pensões representam $19,4 \%$ da renda total dos domicílios. As aposentadorias e pensões pagas por instituto de previdência estadual ou pelo governo federal são as predominantes, representando $14,1 \%$ de toda a renda declarada dos domicílios em 1997; 17,1\% em 2001; 18,5\% em 2003 e 17,9\% em 2007 (HOFFMANN, 2009).

As famílias entrevistadas, tanto no campo quanto na cidade, em sua grande maioria, são assistidas por políticas de assistência social e recebem este incremento mensal na renda, seja no caso das aposentadorias, seja no caso das bolsas de auxílio à família.

No que diz respeito aos Programas Sociais do governo federal tem-se hoje, entre outros, o Programa de Atenção à Pessoa Idosa, Programa de Atenção Integral à Família, Atenção às Pessoas Portadoras de Deficiência, Fome Zero, Bolsa Família, Programa de Combate à exploração Sexual de Crianças e adolescentes, Atenção à Criança de Zero a Seis Anos, Programa de Erradicação do Trabalho Infantil e Programa Agente Jovem de Desenvolvimento Social e Humano (BRASIL, 2006).

O Ministério do Desenvolvimento Social e Combate à Fome - MDS (2006) revela quais são os objetivos de determinados Programas Sociais como, por exemplo, Bolsa Família; Atenção às Pessoas Portadoras de Deficiência; e Programa 
de Atenção à Pessoa Idosa. Programas estes que são, entre outros, os que atendem parte da população entrevistada dos assentamentos rurais e área de periferia urbana de Ribeirão Preto-SP.

Bolsa Família: Este programa unificou todos os benefícios sociais (Bolsa Escola, Bolsa Alimentação, Cartão Alimentação e o Auxílio Gás) do governo federal num único programa. De acordo com o MDS, a medida proporcionou mais agilidade na liberação do dinheiro a quem precisa, reduziu burocracias e criou mais facilidade no controle dos recursos, dando assim mais transparência ao programa. Este é um programa de transferência de renda destinado às famílias em situação de pobreza, com renda per capita de até $\mathrm{R} \$ 100$ mensais, que associa à transferência do benefício financeiro o acesso aos direitos sociais básicos, como por exemplo, saúde, alimentação, educação e assistência social (BRASIL, 2006).

Programa de Atenção à Pessoa Idosa: Este programa tem como objetivo assegurar os direitos sociais do idoso, criando condições para promover sua autonomia, integração e participação efetiva na sociedade, conforme preconizam a Lei Orgânica da Assistência Social - LOAS (Lei 8742, de 07.12.1993) e a Política Nacional do Idoso (PNI). O MDS afirma que se trata de um apoio técnico e financeiro a serviços de proteção social básica e especial, a programas e projetos executados por Estados, municípios, Distrito Federal e entidades sociais, destinados ao atendimento aos idosos com 60 anos (ou mais) vulnerabilizados pela pobreza. Conforme estabelece a Lei 8742, de 07.12.1993, Art.2, inciso V há a garantia de um salário mínimo de benefício mensal à pessoa portadora de deficiência e ao idoso 
que comprovem não possuir meios de prover a própria manutenção ou de tê-la provida por sua família (BRASIL, 2006).

Atenção às Pessoas Portadoras de Deficiência: Este programa tem por objetivo assegurar os direitos sociais da pessoa com deficiência, criando condições para promover sua autonomia, inclusão social e participação efetiva na sociedade, por meio de ações de prevenção de deficiências, habilitação e reabilitação, equiparação de oportunidades e proteção social. Os Serviços de Proteção Socioassistencial à Pessoa com Deficiência são executados de forma direta pelos governos estaduais e municipais ou, de forma indireta, pelas entidades e organizações sociais que integram a rede de proteção social. Segundo o MDS, pessoas com deficiência vulnerabilizadas pela situação de pobreza ou de risco pessoal e social recebem apoio técnico e financeiro a Estados, municípios, Distrito Federal e instituições para o desenvolvimento de ações de proteção social e inclusão das pessoas com deficiência e de suas famílias.

Em conformidade com o MDS, há diferentes modalidades de atendimento: Reabilitação na comunidade; Atendimento domiciliar; Centros-dia; Residência com famílias acolhedoras; Residência em casas-lar; Atendimento em abrigo para pequenos grupos; Apoio à reabilitação; Prevenção das deficiências; Tratamento precoce; Habilitação e reabilitação/atendimento integral; Habilitação e reabilitação/atendimento parcial; Distúrbio comportamental; Bolsa manutenção.

São financiados, também, projetos de manutenção, construção, ampliação e modernização de centros de atendimento a pessoas com deficiência, que visam à 
permanente melhoria da qualidade de vida e do atendimento, e à efetiva inclusão e proteção social (BRASIL, 2006).

Como Soares et al. (2006) destacam que os programas brasileiros de transferência direta de renda à população de baixa renda são importantes porque sem eles dificilmente a erradicação da pobreza e a redução da desigualdade a níveis toleráveis serão possíveis dentro de um horizonte de tempo razoável. Embora estes programas seguramente não constituam uma solução única e permanente para os problemas sociais do país, não há dúvida que esses programas devem fazer parte de qualquer proposta séria de promoção de uma sociedade mais justa.

No caso dos assentamentos rurais onde a percentagem de beneficiários dos programas sociais é alta, sendo $43 \%$ e $50 \%$ para os assentamentos "Mário Lago" e "Sepé Tiarajú", respectivamente, a percentagem de participação desses benefícios na renda familiar é de $51,77 \%$ no assentamento "Mário Lago", e 20,63\% "Sepé Tiarajú". Ressaltando a idade média dos pais nos assentamento "Mário Lago" é de 50 anos. No "Sepé Tiarajú" são 52 anos, enquanto que na área periférica urbana esta idade apresentou-se em torno de 44 anos.

Neste sentido, a percentagem de participação dos programas assistenciais na composição da renda familiar revelou-se como um indicador da demanda por políticas assistenciais e de inclusão. Por sua vez, nas áreas em que são geradas oportunidades de ocupação, trabalho e renda, tais políticas apresentam-se de forma integrativa e reduzem suas ações prioritárias na formação de renda dos cidadãos. Daí a importância da produção de políticas públicas de desenvolvimento nas áreas urbanas e rurais e, principalmente, revela o papel da reforma agrária como política de inclusão (BELLENTANI; SOUZA, 2006). 
Na área periférica urbana de Ribeirão Preto, a percentagem de beneficiários dos programas sociais é de $38 \%$, sendo que o incremento deste benefício na renda das famílias é de $56,85 \%$. Ressalta-se o triste fato de que $12 \%$ da comunidade entrevistada na periferia têm sua renda dependente exclusivamente dos programas sociais (aposentadorias e bolsa família, principalmente) o que confirma a necessidade de oportunidade de emprego e trabalho digno para estas pessoas (Tabela 28).

Tabela 28: Beneficiários de Programas Sociais, Participação na Renda Familiar e de Beneficiários Dependentes nos assentamentos rurais e na área periférica urbana do município de Ribeirão Preto.

\begin{tabular}{|c|c|c|c|c|c|}
\hline$\underline{\text { LOCAL }}$ & $\begin{array}{l}\text { Benef. } \\
\text { Prog. } \\
\text { sociais } \\
(\%)\end{array}$ & $\begin{array}{c}\text { Renda } \\
\text { média anual/ } \\
\text { pessoa (R\$) }\end{array}$ & $\begin{array}{c}\text { Renda } \\
\text { média de } \\
\text { aposentad. } \\
\text { e auxílios } \\
\text { anual/pessoa } \\
(\mathrm{R} \$)\end{array}$ & $\begin{array}{l}\text { Participação das } \\
\text { aposentad. } \\
\text { e auxílios na } \\
\text { renda média } \\
\text { anual/pessoa (\%) }\end{array}$ & $\begin{array}{c}\text { Beneficiários } \\
\text { dependentes } \\
\text { exclusiva/e das } \\
\text { aposentad. } \\
\text { e auxílios } \\
(\%) \\
\end{array}$ \\
\hline $\begin{array}{l}\text { Ass. Mario } \\
\text { Lago }\end{array}$ & 43 & $4.826,76$ & $2.499,00$ & 51,77 & - \\
\hline $\begin{array}{l}\text { Ass. Sepé } \\
\text { Tiarajú }\end{array}$ & 50 & $3.336,48$ & 688,43 & 20,63 & - \\
\hline $\begin{array}{l}\text { Área periferia } \\
(n-13)\end{array}$ & 38 & $4.205,17$ & $2.390,74$ & 56,85 & 12 \\
\hline
\end{tabular}

*aposentadorias (invalidez, idade); e bolsa família.

Fonte: Trabalho de Campo Fev - Jun 2009.

Organização: Natália Freire Bellentani

Os valores recebidos por cada família nos assentamentos e na periferia pelo programa bolsa família variaram entre $R \$ 22,00$ a 92,00 dependendo da renda, idade e número de filhos. Quanto as aposentadorias os valores variaram entre 1 salário mínimo $(R \$ 465,00)$ até $R \$ 1.100,00$.

O que nos chama a atenção é o fato de que não só na periferia aonde as oportunidades de trabalho e autonomia dos sujeitos aparecem claramente com 
menos expressão que nos assentamentos, mas também nas áreas de reforma agrária há uma dependência expressiva dos benefícios e aposentadorias, ainda que não tenhamos identificado pessoas que vivam exclusivamente com esses rendimentos como no caso da periferia, certamente esta não é uma condição que possa configurar de fato a emancipação dos sujeitos por meio da reforma agrária (Tabela 29).

Tabela 29: Tipos de benefícios recebidos (\%) nos assentamentos rurais e na área periférica urbana do município de Ribeirão Preto.

\begin{tabular}{|c|c|c|}
\hline \multirow[b]{2}{*}{$\underline{\text { LOCAL }}$} & \multicolumn{2}{|c|}{ TIPO DE BENEFÍCIO (\%) } \\
\hline & BOLSA FAMÍLIA & APOSENTADORIAS \\
\hline Ass. Mario Lago & 19,04 & 35,71 \\
\hline Ass. Sepé Tiarajú & 50,00 & 12,50 \\
\hline Área periferia $(n-13)$ & 18,57 & 21,42 \\
\hline
\end{tabular}

Fonte: Trabalho de Campo Fev - Jun 2009.

Organização: Natália Freire Bellentani

Vale ressaltar que de acordo com Secretaria Municipal de Assistência Social (2009) em Ribeirão Preto o número de famílias atendidas está em torno de 11.000 e há uma fila de pelo menos três mil famílias a espera para integrarem o programa bolsa família. Segundo Quezada (2009) as famílias que aguardam pela vaga estão cadastradas na prefeitura do município de Ribeirão Preto e atendem as exigências para o recebimento do auxílio (manter cadastro atualizado; filhos com vacinação em dia; freqüência escolar mínima de $75 \%$ para crianças e $85 \%$ para adolescentes). No entanto, conforma afirma a autora, as famílias precisam aguardar para serem chamados pelo governo federal. 
Desta feita, para encerrar esta análise acerca dos aspectos de ordem qualitativa e quantitativa, tanto objetivos como subjetivos, que complementam o conceito de qualidade de vida (sob o olhar das próprias famílias que compõem o universo da pesquisa), buscamos conhecer os sonhos e também os ideais utópicos destas famílias entrevistadas tanto no campo como na cidade. 


\subsection{Sonhos}

"À medida que a necessidade se encontra socialmente sonhada, o sonho se torna necessário..."

(DEBORD, 2000)

Em meio as respostas apreendidas em torno daquilo que os entrevistados afirmaram ter como sonho e/ou projeção de vida futura, foram descritas diversas aspirações acerca de melhores condições de vida; realizações pessoais/familiares; infra-estrutura, entre outros (Tabela 30).

Para facilitar a exposição dos resultados foram definidas três categorias principais que correspondem às questões materiais (Consumo); reprodução social (Trabalho); e questões individuais e familiares (Indivíduo).

Tabela 30: Sonhos nos Assentamentos Rurais e Área Periférica do Município de Ribeirão Preto (\%).

SONHOS* $(\%)$

LOCAL

CONSUMO TRABALHO INDIVIDUO

Ass. Mario Lago

23,80

90,00

26,20

Ass. Sepé Tiarajú

25,00

100,0

25,00

Área periferia $(n-13)$

82,90

7,14

10,00

* os entrevistados puderam responder livremente essa questão e por vezes descreveram mais de um sonho, portanto há valores maiores que $100 \%$.

Fonte: Trabalho de Campo Fev - Jun 2009.

Organização: Natália Freire Bellentani

Os sonhos relacionados ao "consumo" referem-se, fundamentalmente, ao desejo de ter uma casa boa e/ou melhor, vinculado ao sonho da casa própria e ao veemente desejo de obter melhores condições de vida. 
Mas, do que se tratam estas melhorias nas condições de vida dos sujeitos? Em suas respostas, os entrevistados deixam claro tratar-se de elementos como, por exemplo, "ter mais dinheiro; benfeitorias no bairro; mais segurança; menos violência; e mais lazer". Neste tema, a área de periferia registrou dos $82,9 \%$ dos sonhos relativos às questões materiais sendo que, mais da metade $(44,3 \%)$ se referiam à questão da moradia. Estes sonhos relatados pelas famílias na periferia comumente vinculavam-se a falas como dessa moradora do bairro Jardim Salgado Filho 1: "ter a casa é a garantia de futuro que posso deixar para a vida dos meus filhos", neste e em outros relatos identifica-se um forte vínculo entre o consumo e a perspectiva do desenvolvimento enquanto algo que se tem, não do que se é.

Já, os sonhos relacionados ao "trabalho" referem-se à questão da reprodução social. Incluem-se nessa categoria, de acordo com os próprios entrevistados, sonhos que têm relação com a autonomia e trabalho (na periferia: "meu sonho é ser livre e não precisar mais trabalhar para os outros"); a conquista da terra; produção de alimentos de origem animal e/ou vegetal; alimentação garantida e saudável (sem veneno). Sendo assim, no assentamento "Sepé Tiarajú" em torno de $90 \%$ e no assentamento "Mário Lago" 100\%, disseram ter seu sonho realizado, relacionando, em alguns casos, esta realização a outros anseios que permitam a permanência dos mesmos no campo com condições dignas de trabalho e lazer. Na área de periferia urbana esta perspectiva, foi replicada por cerca de $7 \%$ das famílias.

Prosseguindo, apresentamos os sonhos relacionados ao "individuo" que se referem às questões sonhadas de forma (estritamente) individual e que também nos revela que "as necessidades do homem como membro da sociedade não se tornaram necessidades interiores no verdadeiro indivíduo, mas permaneceram 
externas a ele, como necessidades da sociedade (...) se fossem 'necessidades interiores' do homem, então não haveria necessidade de impô-las externamente." (MÉSZÁROS, apud BARROCO, 2003, p. 59)

Esta dimensão abrange sonhos que dizem respeito à realização pessoal ou da família dos sujeitos, como por exemplo, o fato de ver todos vivendo bem e realizados; os filhos criados/educados/formados; e a vontade de permanecer longe da criminalidade/violência. Sonhos estes que, no assentamento "Sepé Tiarajú" apareceram com uma percentagem em torno de $26 \%$, no assentamento "Mário Lago" esse valor chegou a $25 \%$ e na área de periferia urbana esta perspectiva de vida futura, foi em média respondida por $10 \%$ das famílias.

Paulo Freire (1992) nos afirma que "sonhar não é apenas um ato político necessário; mas, também uma conotação da forma histórico-social de "estar sendo" de mulheres e homens." Faz parte da natureza humana que, dentro da história, acha-se em permanente processo de tornar-se [...] Não há mudanças sem sonhos; como não há sonhos sem esperança (FREIRE, 1992, p. 91).

Deste modo, quando as famílias foram inquiridas a respeito do que "precisa ser feito" para que estes sonhos se realizem, em ambos os casos (campo e cidade) a resposta esteve fortemente ligada à necessidade de trabalhar e lutar para conquistar os sonhos (Tabela 31).

Vale ressaltar que não se trata de "dar um número" ao sonho e com isso reproduzir aquilo que criticamos sobre os indicadores sociais, pretende-se sim reconhecer e elucidar questões que fundamentam a percepção dos sujeitos sobre seu desenvolvimento e também sobre as formas de consolidação do mesmo. 
Tabela 31: Freqüência das respostas dadas à pergunta: "O que você precisa para realizar seus sonhos?" nos Assentamentos Rurais e Área Periférica do Município de Ribeirão Preto (\%).

\begin{tabular}{lcccc}
\hline & \multicolumn{4}{c}{ O que precisa para realizar seus sonhos? } \\
\cline { 2 - 5 } LOCAL & TRABALHO & FÉ & SAÚDE & $\begin{array}{c}\text { ORGANIZAÇÃo } \\
\text { SOCIAL }\end{array}$ \\
\cline { 2 - 5 } & 90,5 & 2,38 & 0,00 & 7,14 \\
Ass. Mario Lago & 100 & 0,00 & 0,00 & 0,00 \\
Ass. Sepé Tiarajú & 58,6 & 37,1 & 2,85 & 11,4 \\
\hline Área periferia $(\mathrm{n}-13)$ & Fonte: Trabalho de Campo Fev - Jun 2009. & & &
\end{tabular}

Fonte: Trabalho de Campo Fev - Jun 2009.

Organização: Natália Freire Bellentani

Associada à questão do trabalho para a conquista dos sonhos, nos assentamentos quase a totalidade dos respondentes disseram (90,5\% no "Mário Lago" e 100\% no "Sepé Tiarajú") que somente por meio do trabalho é possível realizar seus sonhos, na fala de uma assentada do "Mário Lago" que diz: "não há outra possibilidade para conquistar seus sonhos, senão por a mão na massa e ir à luta", podemos identificar a perspectiva emancipatória que o trabalho revela na possibilidade de reprodução social.

Já na área de periferia, as respostas dentro dessa categoria, se vincularam à necessidade de ter ajuda do Estado para concretizar aspirações, reforçando a questão das políticas públicas que são recebidas e não demandadas. A necessidade de organizar-se para realizar os sonhos, também foi reforçado pelos entrevistados, no Jardim Aeroporto, um aposentado respondeu que é preciso "ter maior e melhor organização das pessoas na comunidade, para conseguir as coisas"; "ter saúde" também aparece como motivação para realização dos sonhos na periferia; e, por 
fim, os respondentes, principalmente na periferia $(37,1 \%)$, relacionaram a possibilidade de realizar seus sonhos com uma possível sujeição paciente às contrariedades da vida, ou seja, "resignar-se, ter fé e sofrer" foram elementos apontados de forma considerável por eles, ressaltando uma relação muito íntima com a questão da religião que cada um reverência e respeita, participando e/ou cultuando, como poderemos verificar a seguir .

Em suma, pode-se aferir que, a realização de um sonho não diz respeito tão somente a um caminho que é trilhado ou a um futuro que deverá ser vivido, mas, a realização de um sonho está fortemente ligada às atitudes do agora, do presente concreto e objetivo/abstrato e subjetivo. 


\subsection{Religião} “... A angústia religiosa é ao mesmo tempo a expressão da dor real e o protesto contra ela.
A religião é o suspiro da criatura oprimida, o coração de um mundo sem coração, tal como o é
o espírito de uma situação sem espírito. É o ópio do povo..."

(MARX, 1969).

No decurso de nossas indagações acerca dos sonhos dos sujeitos assentados e moradores dos bairros de periferia, nos deparamos com um fato que nos chama a atenção, a questão da religião. Fato esse que se relaciona à subjetividade dos entrevistados, mas também as ações concretas que se materializam no cotidiano das áreas. Especialmente na área de periferia urbana, aonde mais de $37 \%$ dos respondentes relacionaram a possibilidade de tornar real o sonho desejado com a necessidade de ter fé e uma religião. Esta é uma diferenciação muito acentuada em relação aos assentamentos rurais, aonde o trabalho é o elemento determinante para a realização do sonho.

Nesse sentido, ainda que exista uma unidade entre as áreas pesquisadas, ou seja, a classe aonde todos são trabalhadores, elementos como a resignação, sofrimento e fé, nos fazem refletir acerca da possibilidade de emancipação dos sujeitos, sendo que a religião é uma externalidade na subjetividade e faz com que as famílias esperem por algo que deve chegar por meio da religião e não demandem pela transformação de sua realidade.

Na obra intitulada "O livro das religiões" Hellern, Notaker e Gaarder (2000), afirmam que "um rápido olhar para o mundo ao redor mostra que a religião desempenha um papel bastante significativo na vida social e política de todas as partes do globo". E como Marx (1964) salientou "o homem não é um ser abstrato, agachado fora do mundo. O homem é o mundo do homem". 
Mas se este é o caso, como sustenta Löwy (2007) o elemento chave deste novo método para a análise da religião é aproximar-se dela como uma das diversas formas de ideologia - ou seja, da produção espiritual de um povo, da produção de idéias, representações e consciência, necessariamente condicionadas pela produção material e as correspondentes relações sociais (LÖWY, 2007, p.3).

Neste sentido, conforme Hellern et al (2000) "o respeito pela vida religiosa dos outros, por suas opiniões e seus pontos de vista, é um pré-requisito para a coexistência humana".

Desta feita, o complexo, porém, concreto tema da religião também foi investigado nas áreas de assentamentos e rurais e periferia urbana, como forma de compreender como se comportam esses valores instituídos, sejam quais forem, pelas religiões, no dia-a-dia das famílias e em qual medida isto faz parte do desenvolvimento, considerado pelas próprias famílias como humano.

Tabela 32: A diversidade religiosa nos assentamentos rurais e na área periférica urbana do município de Ribeirão Preto (\%).

\begin{tabular}{lcccc}
\hline & \multicolumn{4}{c}{ RELIGIÃO (\%) } \\
\cline { 2 - 5 } LOCAL & CATÓLICOS & EVANGÉLICOS & OUTRAS & "SEM RELIGIÃO" \\
\cline { 2 - 5 } & 52 & 43 & 3 & 2 \\
Ass. Mario Lago & 25 & 75 & 0 & 0 \\
Ass. Sepé Tiarajú & 31 & 58 & 0 & 11 \\
\cline { 2 - 5 } & & & &
\end{tabular}

De acordo com os resultados do Censo IBGE 2000, entre 1991 e 2000, a percentagem de católicos caiu de $83,3 \%$ para $73,9 \%$, a dos evangélicos cresceu de 
9\% para $15,6 \%$ e a dos "sem religião" subiu de $4,7 \%$ para $7,4 \%$.

Antoniazzi (2006) afirma que, a diminuição da percentagem de católicos está associada ao rápido crescimento populacional que neste mesmo período (entre 1991 e 2000) foi de $15,4 \%$, e afirma ainda que "não foram os fiéis que abandonaram a igreja católica, mas que esta deixou sem o devido acompanhamento pastoral importantes grupos da população".

No que tange ao aumento da percentagem dos evangélicos no Brasil, Mendonça, 2004, aponta para a extrema diversidade das igrejas evangélicas, lembrando que estas igrejas estão classificadas geralmente em dois grandes grupos: as tradicionais ou históricas e as pentecostais. De acordo com o Atlas da Filiação Religiosa (2003) entre as igrejas evangélicas tradicionais incluem-se os luteranos, batistas, presbiterianos e metododista e adventistas. Já no segundo grupo (pentecostais) incluem-se as igrejas: Assembléia de Deus; Congregação Cristã do Brasil; Igreja Universal do Reino de Deus; Evangelho Quadrangular; Deus é Amor; entre outras.

Na classificação do IBGE, as "outras religiões" em 1991 representavam 3,6\%, em 2000 esse número caiu para 3,2\%. Neste grupo incluem-se as religiões neocristãs; afrobrasileiras; orientais; e os espíritas.

A pesquisa apresentou uma pequena percentagem em relação a "outras religiões", sendo que nas áreas de assentamentos esse número não passou de 3\% para o Assentamento Mário Lago, onde $52 \%$ são católicos e $43 \%$ evangélicos e foi nula para o Assentamento Sepé Tiarajú, o qual concentrou seus dados entre $25 \%$ de católicos e $75 \%$ de evangélicos. Enquanto que na área de periferia urbana os resultados apontaram para $31 \%$ católicos e $58 \%$ evangélicos, o que chama atenção 
nessa área são $11 \%$ dos entrevistados "sem religião", como apontado anteriormente, no Brasil entre 1991 e 2000 esse número subiu de 4,7\% para 7,4\%. Como expõe Antoniazzi (2006) os "sem religião" são majoritariamente homens, de idade entre 16 e 30 anos de todas as raças, com instrução fraca, com empregos modestos e salários também não elevados. O autor ainda afirma que "nas regiões metropolitanas, os "sem religião" geralmente estão nas periferias e alcançam percentagens muito acima da média geral de 7,4\%".

Como explica Antoniazzi (2006:48), "sem religião" significa abandono das práticas religiosas e dos vínculos com as igrejas, não significa necessariamente ateu.

Vale ressaltar que durante a pesquisa nenhum dos entrevistados, definiu-se como ateu, no Brasil cerca de 1\% declaram-se ateus (IBGE, 2000).

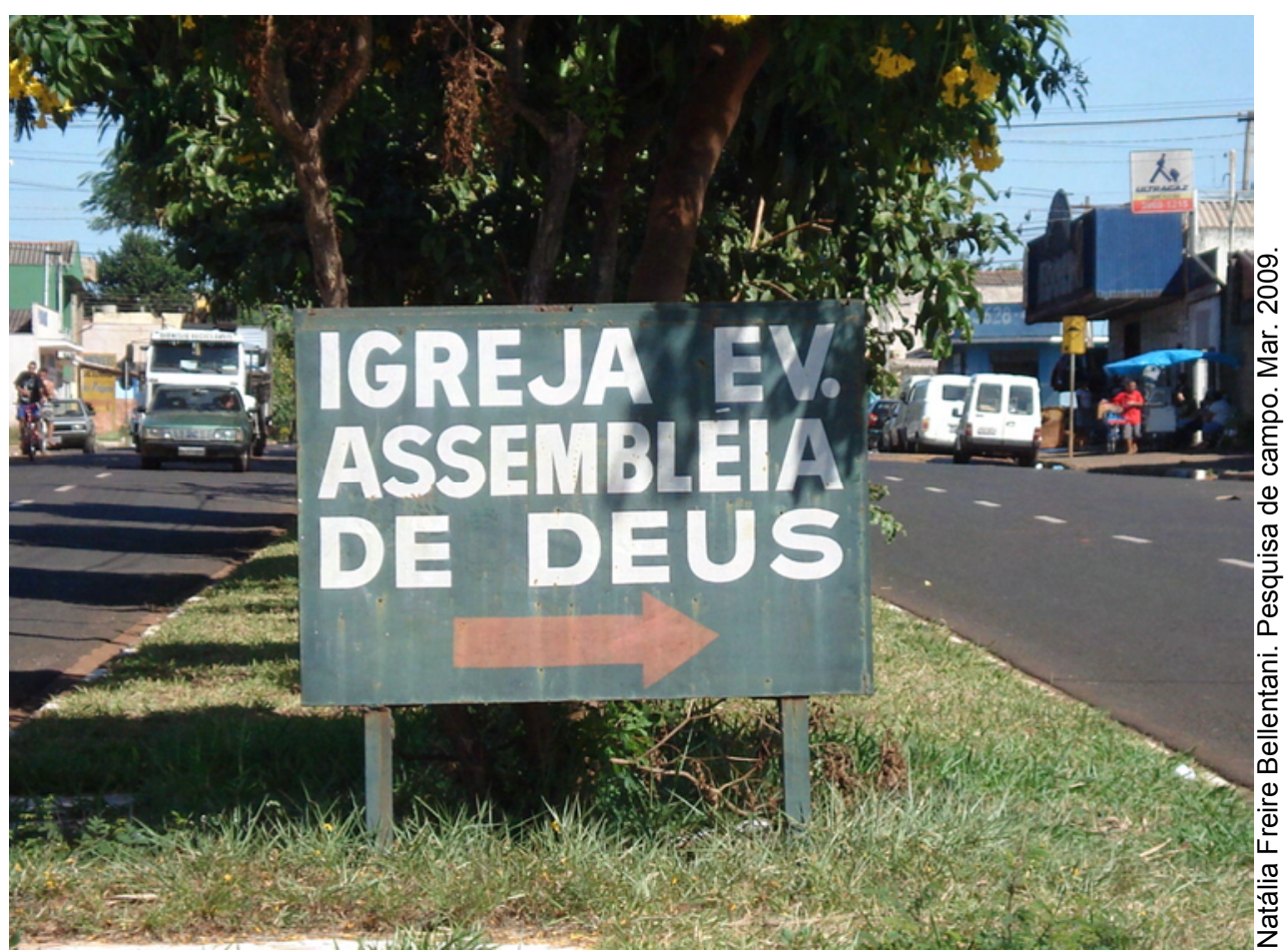

FOTO 13: O caminho está indicado. Bairro Jardim Aeroporto - Abr. 2009. 
Um dos entrevistados disse "buscar na religião a paz que não encontra na realidade vivida cotidianamente no bairro onde mora (Salgado Filho 1) e que por meio da leitura dos textos sagrados pode aprender o que o "Pai" nos ensinou, e assim se tornar um homem melhor". No assentamento "Mário Lago" uma senhora que freqüenta uma Igreja Evangélica do Bairro Jardim Aeroporto (Foto 14) nos contou que "depois que passou a ouvir a palavra do Senhor sua vida e de todos da família mudou muito", ela acrescenta, "meus filhos não gostam muito não, mas eu levo junto comigo para que não entortem nesse mundão."

Esses comentários nos fazem compreender algumas situações e sensações que presenciamos e sentimos repetidas vezes, durante o trabalho de campo, características de cada lugar ou território.

$\mathrm{Na}$ área periférica estudada, por exemplo, algumas "marcas" talvez sejam inconfundíveis para os próprios moradores bem como para os que estão de passagem. O fato da polícia, por exemplo, marcar presença com sua ronda ("tipo passeio", de acordo com alguns moradores) é relevante, tendo em vista que o crime organizado, que também está presente nesses bairros, estabelece normas de convívio e submete os moradores a uma espécie de silêncio "diplomático". Tudo o que é visto, ouvido ou dito, deve ser mantido entre os próprios moradores, neste caso, quando a polícia passa, há uma forte tensão sobre todos, já que se forem questionados sobre qualquer assunto, terão "obrigatoriamente" que silenciar. Ainda que para algumas mulheres (especialmente mães) que foram entrevistadas o fato da polícia "pass(e)ar" ainda é uma maneira de minimizar a marginalidade ou criminalidade, ou ainda, como uma moradora manifestou: "é uma forma de fazer com que meu filho não entorte, já que na igreja eu já desisti de levá-lo, ele não vai”. 


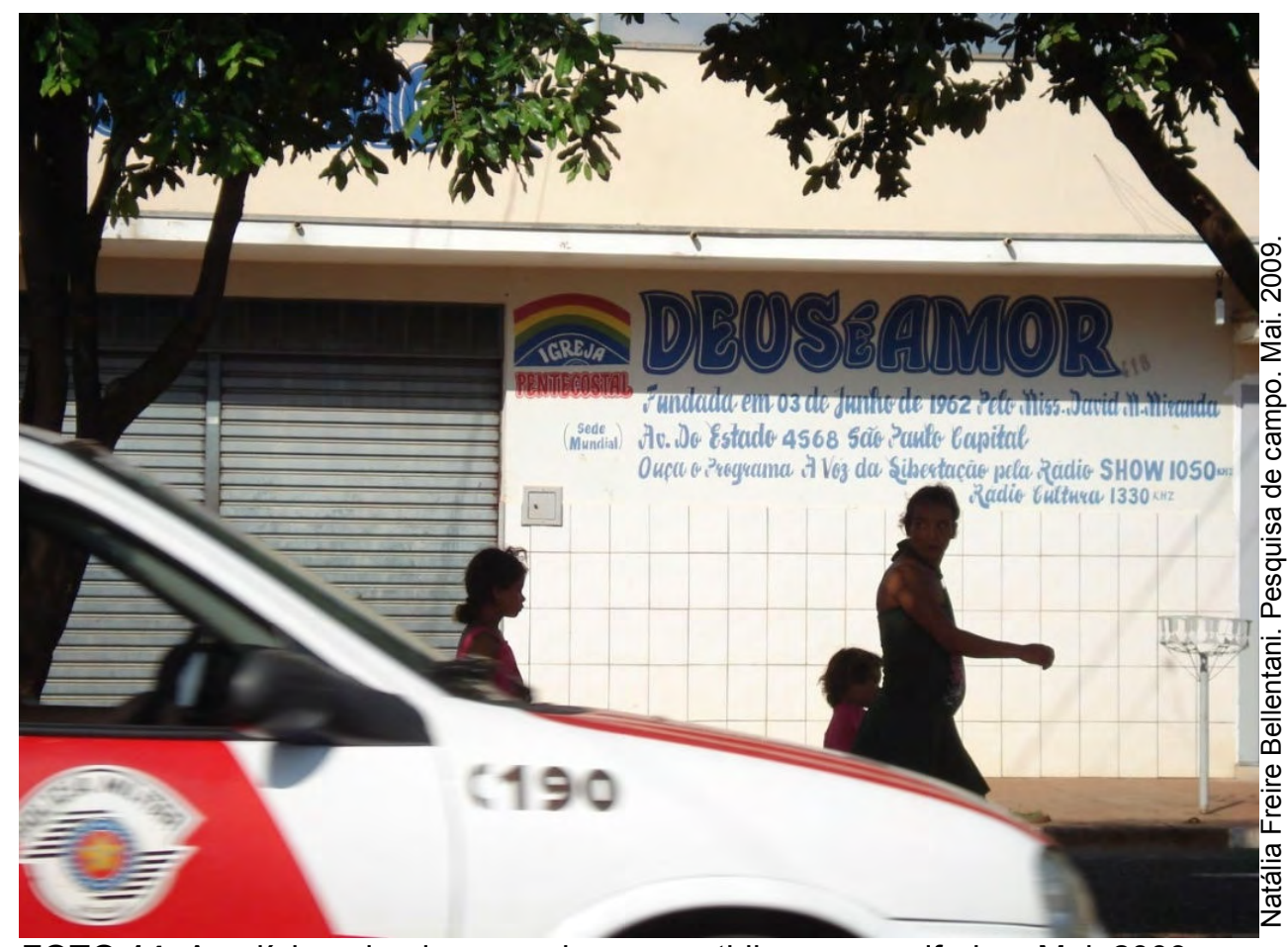

FOTO 14: A polícia, a igreja e as crianças: cotidiano na periferia - Mai. 2009.

De toda forma, a questão da religião e da violência aparece frequentemente de forma articulada, como podemos observar na Foto 14, as pessoas reagem com olhares aflitos, passos rápidos e quase sempre cabeças baixas ao ver a polícia passar. Alguns relatos podem ilustrar esta situação:

Referindo-se às dificuldades e limitações que coexistem com a oportunidade de ensinar e fazer as crianças aprenderem, uma professora do Bairro Jardim Salgado Filho 1, nos contou que certa vez "uma mulher apanhava do marido em casa, quando ela chamou a polícia para ajudá-la e eles chegaram, aproveitaram para também fazer uma 'batida' nos barracos daqueles que traficam droga". E a professora reitera: "isso foi o suficiente para ela ser desmoralizada em sua própria comunidade, até hoje ela sofre as conseqüências, afinal de contas quem chamou a polícia foi ela". 
Fatos assim foram relatados com freqüência em nossas entrevistas na periferia, chamando a atenção inclusive para a questão do território que pontuamos anteriormente, visto que as relações sociais estão submetidas a um poder paraestatal e as contradições e conflitos estão presentes revelando condições que os números dos indicadores possivelmente não dariam conta de explicar.

Outra preocupação dos moradores, no que tange a violência diz respeito aos equipamentos públicos, não raro, de acordo com os relatos, professores das duas escolas que estão localizadas nos bairros pesquisados, são ameaçados pelo "tráfico", particularmente, àqueles que dão aulas de ciências e biologia, por discutirem temas como drogas e educação sexual.

Esta questão também foi apontada para o uso e a demanda do posto de saúde local já que também o "tráfico" pode controlar aquilo que entra (ou quem entra) e sai do posto de atendimento.

Sendo assim, esse emaranhado de relações marcadas pelo poder estatal e para-estatal revela um território em que a sociedade, ou parte dela, que lá reside é a todo o momento subjugada e espoliada de sua autonomia e liberdade. Esta realidade apreendida por meio de uma avaliação qualitativa, dificilmente seria apreendida pelo cálculo do Índice de Desenvolvimento humano, adotado em uma lógica restritiva e expressa por números. 


\subsection{O cálculo do IDH}

A partir dos indicadores de educação, longevidade e renda pode-se calcular o IDH e apresentar como resultados uma variação de zero a um; lembrando que a classificação do índice acontece da seguinte forma: quando o IDH está entre zero e 0.499, é considerado baixo; entre 0.500 e 0.799 , médio e quando está entre 0.800 e um, é considerado alto (SESPA, 2006).

Como mencionado anteriormente, o Brasil entre os anos de 1980 a 2007 sofreu uma evolução do índice de desenvolvimento humano e passou, nos últimos anos, a ser classificado como um país com alto IDH, variando entre 0,805 em 2005 a 0,813 em 2007. (Tabela 33)

Tabela 33: Tendências do índice de desenvolvimento humano no Brasil (1980-2007).

\begin{tabular}{lccccccc}
\hline & \multicolumn{8}{c}{ ANO } \\
\hline \multirow{2}{*}{ IDH Brasil } & 1980 & 1985 & 1990 & 2000 & 2005 & 2006 & 2007 \\
\cline { 2 - 8 } & 0.685 & 0.694 & 0.710 & 0.734 & 0.805 & 0.808 & 0.813
\end{tabular}

Fonte: Relatório de Desenvolvimento Humano 2009 - Ultrapassar Barreiras: Mobilidade e desenvolvimento humanos. Organização: Natália Freire Bellentani

Todavia, no mesmo último Relatório de Desenvolvimento Humano, publicado em 2009 pelo PNUD, aonde o Brasil aparece com alto IDH e comemora-se a posição do país no "ranking do IDH", também aparecem medidas relativas à desigualdade econômica e social e certamente nesse quesito o país não tem tanto o quê comemorar. Por meio do Índice de Gini foi calculada a desigualdade social dos países e o Brasil apresentou uma medida de desigualdade igual a 55, sendo que para este índice o valor zero representa igualdade absoluta e cem a desigualdade 
absoluta. Apenas oito outros países dos 182 estudados pelo PNUD, apresentaram medidas mais altas de desigualdade que o Brasil, como é o caso de Honduras 55,3; Bolívia 58,2; Colombia 58,5; Angola 58,6; Haiti 59,5; Botsuana 61,0; Comores 64,3 e por fim Namíbia 74,3 (RDH, 2009).

Com esse panorama mais uma vez é possível observar a fragilidade e a restrição do Índice de Desenvolvimento Humano, sendo que elementos fundamentais não se revelam e desta forma não revelam também a percepção dos sujeitos sobre o desenvolvimento e as formas de sua consolidação no território.

No caso dos assentamentos rurais e área periférica urbana de Ribeirão PretoSP, para fazer frente aos indicadores oficiais, foi realizado o cálculo do Índice de Desenvolvimento Humano (IDH). (Tabela 34)

Tabela 34: Cálculo do IDH baseado no IDH-Educação, IDH-Longevidade e IDHRenda dos Assentamentos Rurais e Área Periférica do Município de Ribeirão Preto.

\section{LOCAL}

Ass. Mario Lago

Ass. Sepé Tiarajú

Área periferia $(\mathrm{n}-13)$

E: educação; L: longevidade;R: renda

Fonte: Trabalho de Campo Fev - Jun 2009

Organização: Natália Freire Bellentani

$\mathrm{IDH}=\mathrm{E}+\mathrm{L}+\mathrm{R} / 3$

0.612

0.599

0.584

A partir deste cálculo do IDH realizado por meio dos dados coletados na área de periferia urbana de Ribeirão Preto-SP e nos assentamentos rurais, "Mário Lago" e "Sepé Tiarajú", evidencia-se que uma perspectiva que privilegia dimensões métricas, revelando para todas as localidades estudadas, um Índice de Desenvolvimento Humano considerado médio, variando entre 0.584 para a área de periferia urbana, 
0.599 para o assentamento "Sepé Tiarajú" e 0.612 para o assentamento "Mário Lago".

Recordando que no ano de 2000, de acordo com o Instituto de Pesquisa Econômica Aplicada (IPEA), o cálculo do IDH para município de Ribeirão Preto, foi de 0,855 , índice considerado alto e o município do estado de São Paulo que apresentou menor índice foi Itapirapuã Paulista, com IDH igual a 0,645 (Tabela 35). Ou seja, nem mesmo o município com menor índice em todo estado de São Paulo está próximo ao valor calculado para as áreas de assentamentos $(0.599$ e 0.612$)$ e menos ainda para os bairros de periferia do município (0.584). Expressando mais uma vez a lógica contraditória demonstrada pelo índice que nega a perspectiva da marginalidade social a qual Ribeirão Preto também está exposta.

Tabela 35: Cálculo -referente ao ano de 2000- IDH do município de Ribeirão Preto e municípios com maior e menor índice no estado de São Paulo (IPEA, 2000).

\begin{tabular}{ccc} 
Ribeirão Preto & $\begin{array}{c}\text { Município maior IDH-E, } \\
\text { IDH-L, IDH-R e IDH }\end{array}$ & $\begin{array}{c}\text { Município menor IDH-E, } \\
\text { IDH-L, IDH-R e IDH }\end{array}$ \\
\cline { 2 - 4 } IDH $^{*} 0,855$ & 0,919 & 0,645 \\
& (S. Caetano do Sul) & (Itapirapuã Paulista) \\
\hline
\end{tabular}

${ }^{*} \mid \mathrm{DH}-\mathrm{E}+\mathrm{DH}-\mathrm{L}+\mathrm{IDH}-\mathrm{R} / 3$

Fonte: Instituto de Pesquisa Econômica Aplicada (IPEA) 2000.

Organização: Natália Freire Bellentani

Quando avançamos para uma perspectiva qualitativa que não restrinja ou reduza a percepção dos sujeitos sobre determinado estágio de desenvolvimento e nem mesmo as formas de sua consolidação, aponta-se para diferenças suficientemente acentuadas entre as áreas pesquisadas. Quer seja nas relações que permeiam a dimensão de longevidade e educação, quer seja naquela que diz respeito à renda e ao trabalho. 
Deste modo os componentes qualitativos devem ser tomados como referência para a elaboração de políticas públicas, aproximando elementos concretos de elementos abstratos, bem como a objetividade da subjetividade. Questão que está muito vinculada à reprodução social e a realização dos sujeitos que efetivamente reclamam por melhores condições de vida nos territórios envolvidos.

Neste sentido, deve-se re-afirmar que esta dimensão do sujeito, em verdade, é reveladora de uma lógica em que as políticas públicas que alteram efetivamente sua condição de vida não são recebidas, mas demandadas.

\subsubsection{Para você, o que é desenvolvimento humano?}

Em uma perspectiva que diz respeito à sociabilidade e a reprodução social, questionamos os entrevistados sobre aquilo que eles entendem como "desenvolvimento humano" e todos tiveram a oportunidade de responder livremente a essa pergunta sendo que, em muitos momentos, mais de uma resposta foi dada para esta mesma interpelação (Tabela 36). 
Tabela 36: Freqüência das respostas dadas à pergunta: "O que é Desenvolvimento Humano para você?" nos Assentamentos Rurais e Área Periférica do Município de Ribeirão Preto (\%).

O QUE É DH PARA VOCÊ?

\begin{tabular}{lccc}
\cline { 2 - 4 } LOCAL & $\begin{array}{c}\text { POLÍTICAS } \\
\text { PÚBLICAS }\end{array}$ & $\begin{array}{c}\text { FORMAÇ̃̃o } \\
\text { SOCIAL }\end{array}$ & $\begin{array}{c}\text { QUESTÕES } \\
\text { PESSOAISI } \\
\text { INDIVIDUAIS }\end{array}$ \\
\cline { 2 - 4 } Ass. Mario Lago & 57,1 & 50,0 & 52,0 \\
Ass. Sepé Tiarajú & 58,0 & 50,0 & 48,0 \\
Área periferia $(n-13)$ & 78,6 & 20,0 & 25,7 \\
\hline
\end{tabular}

Fonte: Trabalho de Campo Fev - Jun 2009.

Organização: Natália Freire Bellentani

Para a sistematização dos dados foram definidas três categorias que buscam apreender todas as informações coletadas, quais sejam: Políticas Públicas; Formação social; e Questões pessoais e individuais.

Na primeira "categoria" foram incorporados os temas ligados às demandas por políticas públicas, fossem estas relacionadas à educação, saúde e/ou trabalho (geração de renda).

Vale ressaltar que estas demandas, no caso da periferia, estão muito mais vinculadas, nas respostas dos sujeitos, a uma visão da utilidade particular que se têm por meio destas ações do que propriamente a valoração da formação dos sujeitos.

A educação nas áreas de periferia, por exemplo, esteve mais relacionada à obtenção de títulos para a conquista de um espaço no mercado de trabalho do que propriamente ao processo de formação em si e, em alguma medida esta educação 
também está vinculada com a necessidade de acompanhar a tecnologia e ter acesso aos equipamentos sociais públicos que possibilitem este desenvolvimento.

Os respondentes também indicaram questões ligadas à saúde e ao trabalho, com especial destaque para o acesso aos direitos fundamentais. Destaca-se que foi nesta categoria que o maior parte das respostas se concentraram (Mário Lago: 57,0\%; Sepé Tiarajú: 58,0\%; Área periferia: 78,6\%).

Na segunda "categoria" foram incorporadas as matérias vinculadas à reprodução social e realização dos sujeitos. Particularmente nesta categoria podemse destacar questões ligadas a dimensão do trabalho enquanto uma resposta ao que se espera do ser humano para sua plena realização e, neste aspecto, apareceram definições que relacionam o trabalho com a necessidade de estar organizado e trabalhar coletivamente, fazendo uma alusão ao fato de que "sozinho ninguém faz nada", como foi destacado por um assentado no "Mário Lago". Além disso, apontamentos sobre a escola/educação, nas áreas de assentamentos, apareceram relacionados tanto à projeção de vida futura como às perspectivas de reprodução social dos sujeitos.

Nos assentamentos em torno de $50 \%$ dos respondentes quando interpelados sobre o desenvolvimento humano se manifestaram fazendo referência a formação social e na periferia esse número esteve perto de $20 \%$. Um dos moradores do Bairro Jardim Salgado Filho 1 nos respondeu que: "o desenvolvimento humano é o trabalho e a liberdade que se tem para trabalhar, é isso que desenvolve o ser, para isso não basta ter diploma, tem que ser educado, educado para romper com as paredes que vão crescendo na frente da gente no dia a dia, e mais importante disso tudo é que 
você não faz nada disso sozinho, respeitar quem tá do seu lado e crescer junto, é isso."

Para a definição da terceira "categoria" denominada "Questões pessoais e individuais" foram incorporadas as respostas relacionadas aos valores individuais, como por exemplo, equilíbrio e amor próprio; conhecimento das coisas de Deus; fé; determinação, coragem; ter objetivo na vida e força de vontade. Nesta categoria, as respostas no assentamento "Mário Lago", concentraram-se em torno de 52,0\%; no assentamento "Sepé Tiarajú": 48,0\% e na área de periferia: 25,7\%.

Esses elementos para os respondentes são o principal significado para o desenvolvimento humano, de acordo com uma moradora do Bairro Jardim Aeroporto "primeiro preciso ter amor próprio para me desenvolver e para alcançar os objetivos que tenho para minha vida". Nesta categoria o sentido do ter, normalmente sobrepõe-se ao ser, mesmo que em algumas respostas o inverso tenha se manifestado, ainda assim, estas estão relacionadas aos valores individuais do ser humano, implicando em uma perspectiva fragmentada em relação à sociabilidade e reprodução social.

Para compreender estas categorias formuladas a partir das definições e respostas dadas pelos entrevistados, como já foi dito por Aleixo; Bellentani e Souza (2008) é necessário rompermos com esta perspectiva de que o "moderno" é melhor e, reconhecermos suas limitações, significando com isso, essencialmente, criar novas estruturas, pautadas em uma lógica de eqüidade e sustentabilidade, para além da massificação que ocorre. Apontando desta forma para uma nova possibilidade de desenvolvimento humano pautada na autonomia e alteridade dos sujeitos. 
Por conseqüência, para pensar o ser humano em seu pleno desenvolvimento faz-se necessário pensar em um conjunto de dimensões indissociáveis (social, política, econômica, cultura e ambiental) onde as questões humanas, em essência, determinam a relevância das ações do ser social, indicando mudanças concretas para a sociedade. Tendo como ponto de partida a não fragmentação do conhecimento e estabelecendo um diálogo constante entre esta unidade dialética campo/cidade - e a realidade em rápido movimento, entendida em suas múltiplas determinações, para então tratarmos da totalidade, amparados por um senso de realidade que nos envolve e deve ser ampliado pelo conhecimento. 


\section{CONSIDERAÇÕES FINAIS}

Parafraseando Marx, afirmou Lefebvre (1991:145) que a humanidade só levanta problemas que ela mesma pode resolver. "Atualmente, alguns acreditam que os homens só levantam problemas insolúveis. Esses desmentem a razão". Todavia, o autor relembra que "talvez existam problemas fáceis de serem resolvidos, cuja solução está aí bem perto, e as pessoas não levantam".

Corroborando com esta citação percebemos que a dificuldade que está dada ao entendimento do conceito da qualidade de vida e desenvolvimento humano está muito mais relacionada a uma perspectiva reducionista e fragmentada que é aferida ao conceito de desenvolvimento do que propriamente às múltiplas dimensões que do ponto de vista teórico e metodológico apreendem o que se entende por uma efetiva melhoria das condições de vida.

Como pudemos verificar os indicadores das formas de produção e reprodução da vida, particularmente, o Índice de Desenvolvimento Humano (IDH), de fato, não devem ser considerados como mecanismos que restrinjam e ou reduzam a percepção dos sujeitos sobre determinado estágio de desenvolvimento e nem mesmo as formas de sua consolidação.

Logo, observamos que os indicadores de Desenvolvimento Humano em áreas de reforma agrária e periferia urbana em Ribeirão Preto - SP apresentaram-se muito diferentes dos valores que são aferidos ao IDH do município. Se por um lado Ribeirão Preto é conhecida como uma cidade de alto índice de desenvolvimento humano e por isso, muitas vezes, deixa de receber e atender demandas sociais, por 
outro, revela uma realidade de profunda desigualdade e que dificilmente os números dão conta de apreender.

Ainda que os números indicados pelos resultados do cálculo do índice de desenvolvimento humano possam parecer muito semelhantes, entre as áreas estudadas, considerados de desenvolvimento médio, em uma leitura sob os aspectos de ordem qualitativa, tanto objetivos como subjetivos, eles revelam profundas contradições entre as espacialidades pesquisadas.

Podemos destacar, por exemplo, a centralidade que o trabalho assume na reprodução social dos sujeitos nas áreas de reforma agrária e o principal elemento destacado pelos sujeitos na periferia para o desenvolvimento humano: a mercadoria. Da mesma forma destacamos a visão utilitarista que a educação assume na periferia e a valorização que os assentados dão a essa dimensão, tornando-a um valor de vida. Relações contraditórias do campo e da cidade que nos revelam a unidade dialética desse par.

Assim, ao analisarmos os dados concluímos que "só quando o trabalho for efetiva e completamente dominado pela humanidade e, portanto, só quando ele tiver em si a possibilidade de ser" não apenas meio de vida “, mas o" primeiro carecimento da vida", só quando a humanidade tiver superado qualquer caráter coercitivo em sua própria autoprodução, só então terá sido aberto o caminho social da atividade humana como fim autônomo." (LUKÁCS, 1997, p. 40)

Sobre a concepção de autonomia em Marx, destacamos tal afirmação: "Um ser só se tem por autônomo desde que se ergue nos seus próprios pés, desde que a si mesmo deve a sua existência. Um homem que viva da graça de outro se considera como um ser dependente. Mas eu vivo completamente da graça de um 
outro se não lhe dever apenas o sustento da minha vida, mas também se, além disso, ele ainda tiver criado a minha vida." (MARX, 1993, p.102)

Logo, seja no campo ou na cidade, a base para a transformação dos sujeitos, versados hoje como objetos, está na capacidade que cada um apresenta (objetiva ou subjetivamente, individual ou coletivamente) de superar esta lógica opressora que gera a concentração fundiária e está baseada na monocultura e na agroquímica determinando a degradação do ambiente por meio de seu padrão concentrador da propriedade, da renda, da riqueza e do poder político.

Por conseqüência, o grau de autonomia e alteridade que os sujeitos manifestam em meio a construção e transformação do território em que se desenvolvem, revela a possibilidade e a capacidade de melhorar as condições de vida e nesta questão há um extenso terreno para ser semeado, assumindo que uma matéria dialógica que alcança revelações por meio das diversas áreas do conhecimento, configura uma compreensão sobre o desenvolvimento humano mais próxima da realidade e em incontestável movimento. 


\section{"ALEGRIA DE CON-VIVER."}

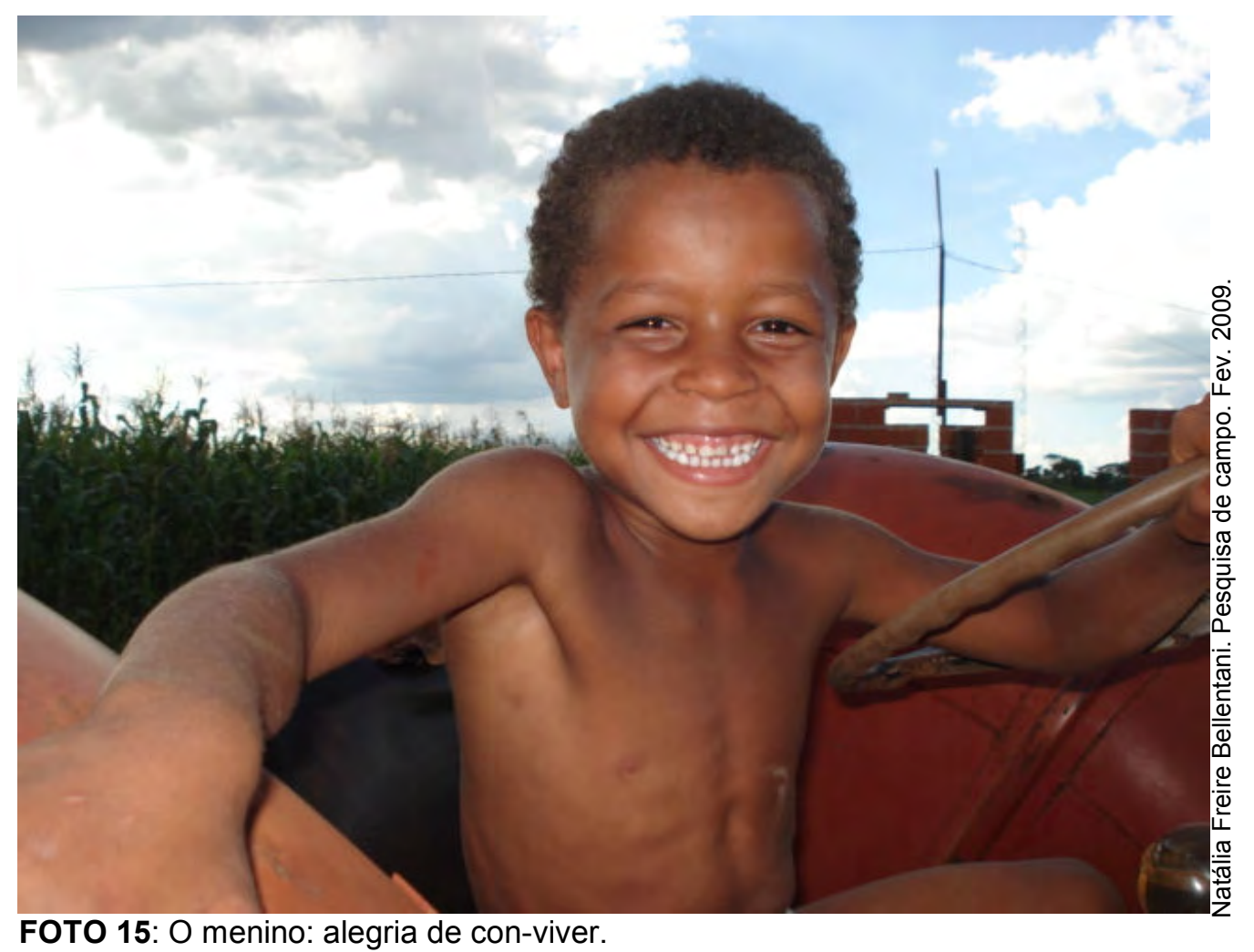

Obrigada! 


\section{REFERÊNCIAS}

ALEIXO, S. S.; BELLENTANI, N. F.; SOUZA, J. G. O aspecto ontológico da tecnologia: possibilidade de autonomia e alteridade dos sujeitos. In: Anais XV ENG: O Espaço não pára. Por uma AGB em movimento, 2008, São Paulo.

ALMEIDA, S. et al. Revista Agriculturas, experiência em agroecologia gerandoriquezas e novos valores. Rio de Janeiro: AS- PTA, v. 2, 2005.

ANDRADE, C. D. de. O Homem; As viagens. As impurezas do Branco. Rio de Janeiro, José Olympio, 1973.

ANJOS, A. F.; CHAVEIRO, E. F. A Periferia Urbana em questão: um estudo socioespacial de sua formação. Boletim Goiano de Geografia, v. 27, p. 181-197, 2007.

ANTONIAZZI, A. Por que o panorama religioso no Brasil mudou tanto? 3. Ed. Paulus: São Paulo, 2006.

ARENDT, H. Entre o passado e o futuro. São Paulo: Perspectiva, 1972, p. 234-247.

AUGUSTO, M. H. O. Cidade de muros: crime, segregação e cidadania em São Paulo. Rev. bras. Ci. Soc., São Paulo, v. 17, n. 48, Feb. 2002 . Disponível em $<$ tttp://www.scielo.br/scielo.php?script=sci_arttext\&pid=S0102-

69092002000100017\&Ing=en\&nrm=iso>. Acesso em: Jan. 2009.

AUQUIER P.; SIMEONI M. C.; MENDIZABAL H. Approches théoriques et méthodologiques de la qualité de vie liée à la santé. Revue Prevenir 33:7786.1997.

BALDUÍNO, T. O Campo no Século XXI: Território de vida, de luta e de construção da justiça social. In: Oliveira, A. U. Marques, M.I.M. (Org.). O Campo no Século XXI. $1^{a}$ ed. São Paulo: Paz e Terra/Casa Amarela, 2004, p. 19-25.

BARROCO, M. L. Ética e Serviço Social . 2.ed. São Paulo: Cortez, 2003.

BELLENTANI, N. F.; SOUZA, J. G. Indicadores de Desenvolvimento Humano em assentamentos rurais e periferia urbana: estudo de caso dos assentamentos de Córrego Rico (Jaboticabal-SP), Reage Brasil (Bebedouro-SP) e área periférica urbana (Jardim Alvorada) Jaboticabal-SP. In: Anais XLIV Congresso Brasileiro de Economia e Sociologia Rural, 2006, Fortaleza-CE. Anais do XLIV Congresso Brasileiro de Economia e Sociologia Rural. Fortaleza-CE: UFCE/SOBER, 2006. v. 1

BONATO, J. A. Delegacia Regional do Trabalho registra 416 mortes, maioria por acidentes - Gazeta de Ribeirão - Julho 2006 - sexta-feira 7 de julho de 2006. 
Disponível em <http://74.125.93.132/search?q=cache:ywZYbPn3A38J:www.sucreethique.org/Mortes-no-campo-sao-416.html+bonato+mortes+cana\&cd=1\&hl=ptBR\&ct=clnk\&gl=br>. Acesso em Set. de 2008.

BRANDÃO. C. R. O que é educação, 33ª Ed. Brasiliense, São Paulo. 1995.

BRASIL. MINISTÉRIO DO DESENVOLVIMENTO SOCIAL E COMBATE À FOME. Disponível em: <http://www.mds.gov.br/programas/programas.asp>. Acesso em maio de 2006.

CABRAL, F. Fundamentos da Arquitetura paisagista. Instituto de Conservação da Natureza, Lisboa, 1993.

CABRAL FILHO, A. V. Sociedade e tecnologia digital: entre incluir ou ser incluída. Liinc em Revista, v. v2, p. 1, 2006.

CARLOS, A. F. A. A questão da cidade e do campo. Teorias e políticas. Mercator, Fortaleza-CE, v. 5, p. 8-13, 2004.

CARLOS, A. F. A. A (re)produção do espaço urbano. São Paulo: Edusp, 1994. $270 p$.

CHAUÍ, M. Convite à Filosofia. Unidade 7. As ciências. Cap. 4. As ciências humanas. Ed. Ática, São Paulo, 2000.

CONAB - Companhia Nacional de Abastecimento Programa de Aquisição de Alimentos - PAA: $O$ que é O PAA? Disponível em <http://www.conab.gov.br/conabweb/agriculturaFamiliar/paa_o_que_e.html>. Acesso em maio de 2009.

CORAGGIO, J.L. Desenvolvimento humano e educação: o papel das ONGs latino-americanas na iniciativa da educação para todos. 3.ed. São Paulo: Cortez, 2000. 277 p.

DEBORD, G. A sociedade do espetáculo; tradução Estela dos Santos Abreu. $2^{a}$ reimpressão, maio de 2000. Rio de Janeiro: Contraponto.

DEMO, P. Avaliação qualitativa: polêmicas do nosso tempo. 7. Ed. ver. Campinas, SP: Autores Associados, 2002. 109p.

DICCIONARIO SOVIÉTICO DE FILOSOFÍA. Crítica del Programa de Gotha. Ediciones Pueblos Unidos, Montevideo 1965. Disponível em < http://www.filosofia.org/enc/ros/critica.htm>. Acesso em Julh 2009.

DOWBOR, L. Estamos falando de um assalto. Entrevista por Fernando Taquari Ribeiro. Revista Desafios do Desenvolvimento, IPEA, São Paulo, 2009. 
ELIAS, D. Meio Técnico-Científico-Informacional e urbanização na região de Ribeirão Preto (SP). São Paulo : FFLCH-USP, 1996. 274p. (Tese de dourado em Geografia) - Faculdade de Filosofia, Letras e Ciências Humanas - Departamento de Geografia. Universidade de São Paulo - USP, São Paulo.

ENGELS,F. A Origem da Família, da Propriedade Privada e do Estado, Rio, Ed. Civilização Brasileira, 1981.

FERREIRA V. S. O conceito de abandono escolar. (Jan 2009) Disponível em: $<$ http://www.ajic-assoc.com/index.php?paginas=22\&id_cod=31> Acesso em Abr 2009.

FERNANDES, M. E. (Org.); VALENCIANO, M. C. M. (Org.); CAMPOS, M. S. V. de O. (Org.); ADAS, S. (Org.). A cidade e seus limites: as contradições do urbano na California Brasileira.. 1. ed. São Paulo/SP: Annablume/FAPESP, 2004. v. 1. 347 p.

FIGUEIREDO, G. C. Experiência e luta pela terra: o assentamento Sepé Tiaraju e o MST. Ribeirão Preto, 2009. 397 p. : il.; $30 \mathrm{~cm}$. Tese (doutorado) apresentada à Faculdade de Filosofia, Ciências e Letras de Ribeirão Preto / USP - Dep. de Psicologia e Educação. Ribeirão Preto, SP. 2009.

FREITAS, E. P. De. Metamorfoses socioespaciais: os dilemas da modernização agrícola na região de Ribeirão Preto (SP). Anais $1^{\circ}$ SIMPGEO/SP, Rio Claro, 2008.

FREIRE, P. Educação com prática da liberdade. 11ed. Rio de Janeiro: Paz e Terra, 1980.

FREIRE, P. Pedagogia da esperança. São Paulo: Paz e terra, 1992, pág. 91-2.

GARCIA Jr., A. Terra de Trabalho: Trabalho Familiar de Pequenos Produtores. Rio de Janeiro: Paz e Terra, 1983.

GARCIA Jr., A. Geração de rendas, sua distribuição e trajetórias diferenciais em assentamentos de reforma agrária no Brasil (1985-1989). In: Romeiro, A.; Guanziroli, C.; Leite, S. (Orgs.). Reforma agrária: produção, emprego e renda. Petrópolis: Vozes, 1994.

GIANCHELLO A. L. Health outcomes research in Hispaniccs/Latinos. Journal of Medical Systems 21(5): 235-254. 1996.

GRAZIANO DA SILVA, J. O Novo rural Brasileiro. Campinas: Unicamp, 1999.

GOLDFARB, Y. A luta pela entre o campo e a cidade: As Comunas da Terra, sua gestação, principais atores e desafios. Dissertação (mestrado) - Faculdade de Filosofia, Letras e Ciências Humanas - Departamento de geografia. Universidade de São Paulo - USP. São Paulo, 2007. 
GUIMARÃES, J. R. S.; JANNUZZI, P. M. Indicadores sintéticos no processo de formulação e avliação de políticas pública: limites e legitimidades. In: Anais XIV Encontro Nacional de Estudos Populacionais - ABEP, 2004, Caxambu. XIV Encontro Nacional de Estudos Populacionais - ABEP. Campinas: ABEP, 2004. v. 1. p. 01-18.

GADOTTI, M. Perspectivas atuais da educação. São Paulo Perspec., São Paulo, v. 14, n. 2, Jun 2000 Disponível em: <http://www.scielo.br/scielo.php?script=sci_arttext\&pid=S0102$88392000000200002 \&$ Ing=en\&nrm=iso>. Acesso em Julh 2009.

GADOTTI, M. A questão da educação formal/não formal. Institut International des Droits de L'enfant (ide) Droit à L'éducation: solution à tous les problèmes ou problème sans solution? Sion (Suisse): 2005.

HAQ, U. M. O Paradigma do Desenvolvimento Humano. PUC Minas Virtual. Introdução ao Desenvolvimento Humano: Conceitos Básicos e Mensuração. Disponível em <soo.sdr.sc.gov.br/index.php?option=com_docman\&task=doc_download\&gid=200$>$. Acesso em Jan. 2008.

HABERMAS, J. Técnica e Ciência enquanto “ideologia”. Lisboa, Edições 70, 1968. 148p.

HEIDRICH, A. Fundamentos da Formação do Território Moderno. Boletim Gaúcho de Geografia, n² 23, AGB - Seção Porto Alegre,1998.

HELLERN, V.; NOTAKER, H.; GAARDER, J. O livro das religiões. São Paulo: Companhia das Letras, 2000.

HOFFMANN R. Desigualdade da distribuição da renda no Brasil: a contribuição de aposentadorias e pensões e de outras parcelas do rendimento domiciliar per capita. Economia e Sociedade, Campinas, v. 18, n. 1 (35), p. 213-231, 2009.

JANNUZZI, P. M. Indicadores sociais no Brasil: conceitos, fontes de dados e aplicações: 3. (Ed.) Campinas: Alínea, 2004. 141p.

KANT, I. Crítica da Razão Pura, editora Clauste-Gulbenkian, Lisboa, 2001.

KOGA, D. Medidas de cidades: entre territórios de vida e territórios vividos. São Paulo: Cortez, 2003.

LEFEBVRE, H. A produção do espaço. Paris: Armand Colin, 1974.

LEFEBVRE, H. A vida cotidiana no mundo moderno. São Paulo: (Ed). Ática, 1980. 
LEFEBVRE, H. O direito à cidade. São Paulo: Moraes, 1991.

LEFEBVRE, H. Lógica formal, lógica dialética. Rio de Janeiro: Civilização brasileira, 1995.

LEITE, S. P. (2003), Orçamentos familiares e estratégias socioeconômicas em assentamentos rurais: apontamentos ao debate sobre multifuncionalidade da agricultura brasileira. In: Seminário franco-brasileiro de pesquisa sobre a multifuncionalidade da agricultura. Florianópolis/SC, 23p.

LÖWY, M. Marxismo e religião: ópio do povo? In: A teoria marxista hoje. Problemas e perspectivas. Boron, A. A.; Amadeo, J.; Gonzalez, S. 2007. Disponível em <http://bibliotecavirtual.clacso.org.ar/ar/libros/campus/marxispt/cap >. Acesso em Abr 2009.

LUKÁCS, G. Os princípios ontológicos fundamentais de Marx. São Paulo: Ciências Humanas, 1979.

LUKÁCS, G. As bases ontológicas do pensamento e da atividade do homem. In: Núcleo de Estudos e Aprofundamento Marxista. Ontologia social, formação profissional e política. São Paulo: PUC-SP, 1997. v.1. p. 08-44.

MORAES, A. C.R. Espaço e contemporaneidade. Disponível em < http://www.cpflcultura.com.br/video/integra-espaco-e-contemporaneidade-antoniocarlos-robert-moraes>. Acesso em Jun 2009.

MORAIS, P. Z. M. Lazer: qualidade de vida e cidadania. Licere. Belo Horizonte, v.2, n.1, 1999.

MARX, K. O capital: crítica da economia política. Livro 1: O processo de produção do capital. 6. ed. Rio de Janeiro: Civilização Brasileira, 1980.

MARX, K. O 18 Brumário e Cartas a Kugelman. Rio de Janeiro, Paz e Terra, 1969.

MARX, K. ENGELS, F. On religion. Nova York, Schoken Bookes,1964.

MARX, K. Manuscritos económico-filosóficos de 1844. Trad. Maria Antonia Pacheco. Lisboa - Portugal: Avante, 1993.

MONTEIRO F. M. Agroecologia faz de assentamento modelo de sustentabilidade. $2007 . \quad$ Disponível em http://www.reporterbrasil.com.br/exibe. php?id=1223 >. Acesso em Jan 2009.

MOREIRA, R. O que é geografia. São Paulo: Editora Brasiliense S. A., 1985.

MOREIRA, R. Para Onde Vai o Pensamento Geográfico. 1a.. ed. São Paulo: Contexto, 2006. 191 p. 
MENEGAT, M. O olho da barbárie. São Paulo: Expressão Popular, 2006. 352p.

MARTINS, J. S. Subúrbio - vida cotidiana e história no subúrbio da cidade de São Paulo: São Caetano, do fim do império ao fim da república velha. São Paulo: Hucitec, 1992.

MARTINS, J. S. A sociabilidade do homem simples. São Paulo: Hucitec, 2000.

MARTINS, J. S. A aparição do demônio na fábrica - origens sociais do eu dividido no subúrbio operário. São Paulo: (Ed.) 34, 2008

MOLES, A . 1984. Labyrinthes du vécu; l'espace, matière d'action. Paris, Librairie Méridiens.

MEDEIROS, L. et al. (org.). Assentamentos Rurais: uma visão multidisciplinar. São Paulo: Editora da Universidade Estadual Paulista, 1994. 307 p.

MÉSZÁROS, I. A teoria da alienação em Marx. Coleção mundo do Trabalho (Coord. Ricardo Antunes) Ed. Boitempo: São Paulo, 2006.

MINAYO, M. C. S.; HARTZ, Z. M.; BUSS, P. M. Qualidade de vida e saúde: um debate necessário. Ciênc. saúde coletiva, Rio de Janeiro, v. 5, n. 1, 2000. Disponível em: <http://www.scielo.br/scielo.php?script=sci_arttext\&pid=S1413$81232000000100002 \&$ Ing=pt\&nrm=iso>. Acesso em Ago. 2006.

MINISTÉRIO DAS COMUNICAÇÕES. Hélio Costa diz a prefeitos que inclusão digital é prioridade. Disponível em < http://www.mc.gov.br/noticias/2009/heliocosta-diz-a-prefeitos -que-inclusao-digital-e>. Acesso em Mar.2009

NAHAS, M.I.P. Bases teóricas, metodologia de elaboração e aplicabilidade de indicadores intra-urbanos na gestão municipal da qualidade de vida urbana em grandes cidades: o caso de Belo Horizonte. Tese de Doutorado. Programa de Ecologia e Recursos Naturais. Universidade Federal de São Carlos. São Carlos: UFSCar/Centro de Ciências Biológicas e da Saúde. 2002. 373 p.

NUSSBAUM, M.; SEN, A. La calidad de vida (Introdução). México: Fondo de Cultura Económica; The United Nations University, 1998.

OLIVEIRA, A. U. A Geografia Agrária e as Transformações Territoriais Recentes no Campo Brasileiro. In: Novos Caminhos da Geografia, (Ed.) Contexto, São Paulo, 1999.

OLIVEIRA, A. U. Geografia Agrária: perspectivas no início do Século XXI. In:

OLIVEIRA, A. U. MARQUES, M.I.M. (Org.). O Campo no Século XXI. $1^{\text {a }}$ ed. São Paulo: Paz e Terra/Casa Amarela, 2004, p. 29-70. 
OLIVEIRA, A. U. As terras improdutivas no Brasil e a reforma agrária. 2007. Disponível em:

<http://www.radioagencianp.com.br/index.php?option=com_content\&task=view\&id=2 335\&Itemid=43>. Acesso em Mai de 2008.

OLIVEIRA, A. U. Território de quem? Revista sem Terra, v. 47, p. 17-31, 2008.

PROGRAMA DAS NAÇÕES UNIDAS PARA O DESENVOLVIMENTO - PNUD. Disponível em <http://www.pnud.org.br/idh/>. Acesso em Mai 2005.

QUEZADA, A. Natal de Fome. Jornal A CIDADE. Ribeirão Preto - SP, p.A-5, 16 Dez. 2009.

RACY, S. Direto da fonte. O Estado de São Paulo. São Paulo - SP, Jul. 2009.

RAFFESTIN, C. Por uma Geografia do Poder. Ática, São Paulo, 1993.

RAMOS, D. A. R. Território e indústria: as empresas metalomecânicas em Sertãozinho. Dissertação (Mestrado em Geografia) - Unesp Presidente PrudenteSP. 2009.

RDH - Relatório de Desenvolvimento Humano 2009 - Ultrapassar barreiras:

Mobilidade e desenvolvimento humanos. Programa das Nações Unidas para o Desenvolvimento (PNUD). New York- USA. 2009.

REIS, A. T.; SOUZA, J. G. Produtividade e salários: elementos para a compreensão da desigualdade social no setor sucroalcooleiro. Anais da Associação dos Geógrafos Brasileiros, 2008.

RUFINO NETTO A. Qualidade de vida: compromisso histórico da epidemiologia, pp.11-18. In MFL Lima e Costa \& RP Sousa (orgs.). Qualidade de Vida: Compromisso Histórico da Epidemiologia. Coopmed/Abrasco, Belo Horizonte. 1994.

SALAS, J. C. G. Sistemas de Indicadores de Qualidade de Vida: Análise das experiências de Belo Horizonte, Ontário, Porto e Chillan e Ovale. 2005. 148p. Dissertação (mestrado em Engenharia Urbana) - Universidade Federal de São Carlos, São Carlos.

SAMPAIO P. de A. Dossiê Reforma Agrária - Da alienação à cidadania. 2003 Disponível

<http://www2.fpa.org.br/portal/modules/news/article.php?storyid=1960>. Acesso em Set 2007.

SANCHEZ, 2006. Revista da Associação Nacional dos Programas de PósGraduação em Comunicação | E-compós, Brasília, v.11, n.2, maio/ago. 2008. Disponível em <www.e-compos.org.br>. Acesso em: Abr. 2009. 
SANTOS, A. C. As contradições da economia de mercado:um olhar sobre a renda da agricultura agroecológica. Agriculturas, v. 2, $n^{\circ} 3$, p.07-11, out 2005. 149 SIT (SISTEMA DE INFORMAÇÕES TERRITORIAIS). Disponível em: http://www.mda.gov.br. Acesso em Abr. 2008.

SANTOS, M. A natureza do espaço: Técnica e Tempo, Razão e Emoção. São Paulo: Edusp, 2002. 384p. (Coleção Milton Santos; 1).

SANTOS, M. Técnica, Espaço e Tempo: globalização e Meio-técnico-cientifico informacional. São Paulo : Editora Hucitec, 1994. 190p.

SANTOS, M. O espaço do cidadão. 7. (Ed.) São Paulo: EDUSP, 2007.

SANTOS, M. Pensando o Espaço do Homem. São Paulo: Hucitec, 1980.

SANTOS, M. O retorno do território. In: OSAL : Observatorio Social de América Latina. Año 6 no. 16 (jun.2005). Buenos Aires : CLACSO, 2005- Disponível em:<http://bibliotecavirtual.clacso.org.ar/ar/libros/osal/osal16/D16Santos.pdf>.

Acesso em Mai 2007.

SANTOS, A. C. As contradições da economia de mercado: um olhar sobre a renda da agricultura agroecológica. 2005. Disponível em < www.jornadadeagroecologia.com.br/.../18/107301652538ica. doc >. Acesso em Maio 2009.

SAQUET, M. A. Abordagens e concepções de território. 1. ed. São Paulo: Expressão Popular, 2007. 200 p.

SCOPINHO, R. A. O processo organizativo do Assentamento sepé Tiarajú-SP: o sentido e os caminhos da cooperação. São Paulo: Grafset- Ribeirão Preto, 2007.

SEN, A. K. Desenvolvimento como Liberdade. São Paulo: Companhia das letras, 2000.

SILVA, J. G. O novo rural brasileiro. Campinas, Unicamp/IE, 1999.

SILVA, M. A. M. Espaço, Tempo e Memória ("notas de aula"). Disciplina do Programa de Pós Graduação em GEOGRAFIA- Universidade Estadual Paulista FCT- Presidente Prudente -São Paulo. 2007.

SOARES F. V.; SOARES S.; MEDEIROS M.; OSÓRIO R. G.. Programas de transferência de renda no Brasil: Impactos sobre a desigualdade. IPEA, Brasília, 2006.

SOTO, W. H. G. O subúrbio e a periferia: um novo olhar do espaço a partir de Marx, Henri Lefebvre e José de Souza Martins. In: Anais XII Encuentro de geografos de América Latina - caminando en una América Latina en transformación, 2009, 
Montevidéu. 12 Encuentro de geografos de América Latina - caminando en una América Latina en transformación, 2009.

SOUZA . J. G. A Geografia Agrária e seus elementos de crítica ao avanço do capital monopolista no campo brasileiro. In: Simpósio Internacional de Geografia Agrária I IV Simpósio Nacional de Geografia Agrária jornada Orlando Valverde SINGA, 2007, Londrina-PR. Anais III Simpósio Internacional de Geografia Agrária / IV Simpósio Nacional de Geografia Agrária jornada Orlando Valverde SINGA. LodrinaPR : UEL-Editora, v. 1. p. 1-1. 2007.

SOUZA . J. G. Questão de Método: a homogeneização do território rural paulista. Tese (Livre-docência). 2008.161 f. Universidade Estadual Paulista. FCAV. Jaboticabal -São Paulo. 2008

SPOSITO, M. E. B. A questão cidade-campo: perspectivas a partir da cidade. In: SPOSITO, M. E. B.; WHITACKER, A. M. (orgs.). Cidade e Campo: relações e contradições entre urbano e rural. São Paulo: Expressão Popular, 2006.

STAHEL, A. W. Capitalismo e entropia: os aspectos ideológicos de uma contradição e a busca de alternativas sustentáveis. In: CAVALCANTI, C. (org.).

Desenvolvimento e natureza: estudos para uma sociedade sustentável. 3. (Ed.) São Paulo: Cortez; Recife: Fundação Joaquim Nabuco, cap. 6, p. 104-127. 2001.

SUERTEGARAY, D. M. A. Espaço Geográfico Uno e Múltiplo. Revista Geocrítica Scripta Nova Revista Eletrónica de Geografía y Ciencias Sociales, Barcelona, v.93, 2001.

TAVARES, M. M. V. Abandono escolar: Um Contributo para o seu Estudo no Nosso País. Lisboa: Dissertação de Mestrado em Sociologia. ISCSP. 1990.

UNICEF - Fundo das Nações Unidas para a Infância. O Direito de Aprender: Potencializar avanços e reduzir desigualdades. Coord. SILVA M. S. e ALCÂNTARA P. I. - Brasília, DF: UNICEF, 2009.

VEIGA, J. E. Cidades Imaginárias: O Brasil é menos urbano do que se calcula. Editora Autores Associados, Campinas, São Paulo, 2002.

VIANA, G.; SILVA, M.; DINIZ, N (orgs.) Manifesto Ecossocialista - 1991. In: O Desafio da sustentabilidade: Um debate socioambiental no Brasil. São Paulo: Fundação Perseu Abramo, 2001.

WAISELFISZ. J. J. Mapa das desigualdades digitais no Brasil. Brasília: RITLA; Instituto Sangari; Ministério da Educação, 2007. 
ANEXO 1 


\section{QUESTIONÁRIO PARA AVALIAÇÃO DO ÍNDICE DE DESENVOLVIMENTO HUMANO}

EM ASSENTAMENTOS RURAIS E ÁREAS DE PERIFERIA URBANA

Nome do entrevistado:

Localidade:

1. Educação

\begin{tabular}{|c|c|c|c|c|c|c|c|}
\hline & $\begin{array}{c}\text { GRAU } \\
\text { PARENTESCO / SEXO }\end{array}$ & IDADE & ALFABETIZADOS & TEMPO DE ESCOLA & $\begin{array}{c}\text { MATRICULADOS } \\
2008\end{array}$ & TRABALHAM & ALFABETIZAÇÃo DIGITAL \\
\hline 1 & & & & & & & \\
\hline 2 & & & & & & & \\
\hline 3 & & & & & & & \\
\hline 4 & & & & & & & \\
\hline 5 & & & & & & & \\
\hline 6 & & & & & & & \\
\hline 8 & & & & & & & \\
\hline 9 & & & & & & & \\
\hline 10 & & & & & & & \\
\hline 11 & & & & & & & \\
\hline 12 & & & & & & & \\
\hline 13 & & & & & & & \\
\hline 14 & & & & & & & \\
\hline
\end{tabular}

1.1. Localização da escola

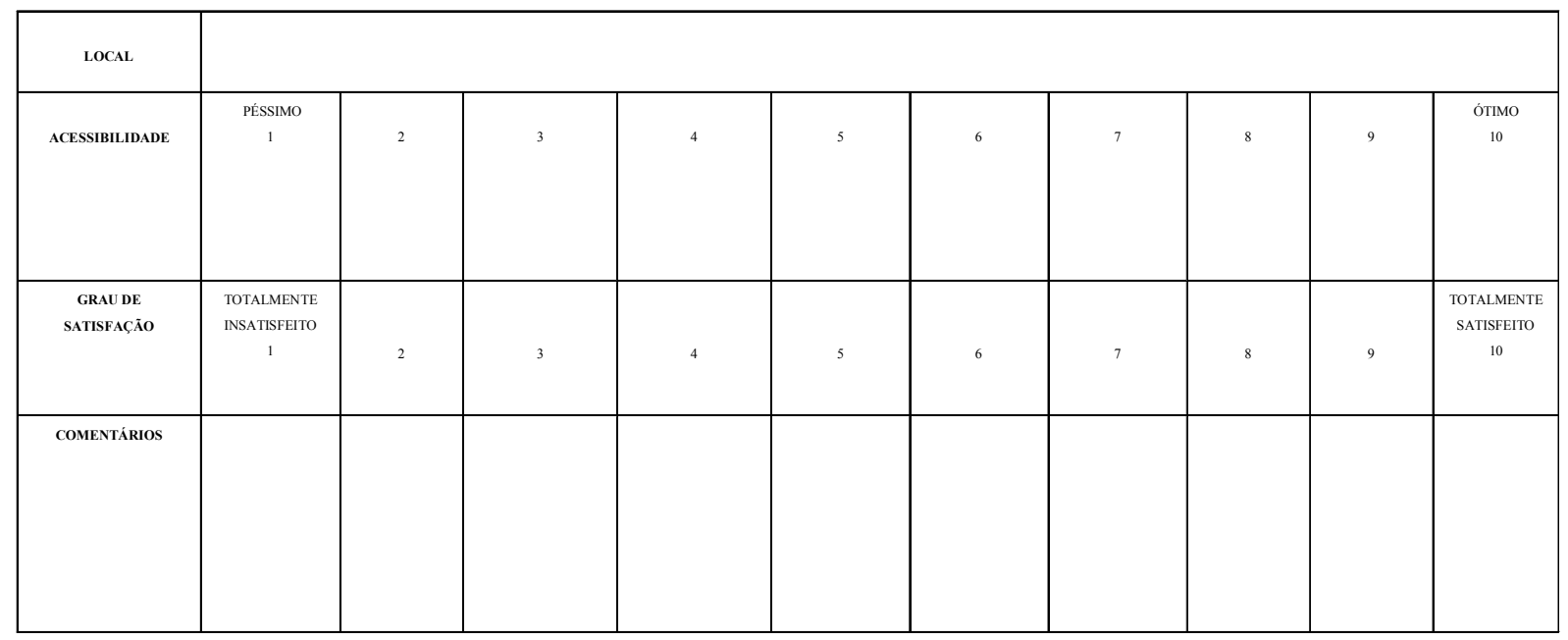


1.2. Abandono (motivo)?

1.3. Atividades extra-curriculares (Escolas; ONGs; Associações; Universidades; Movimentos Sociais; etc )

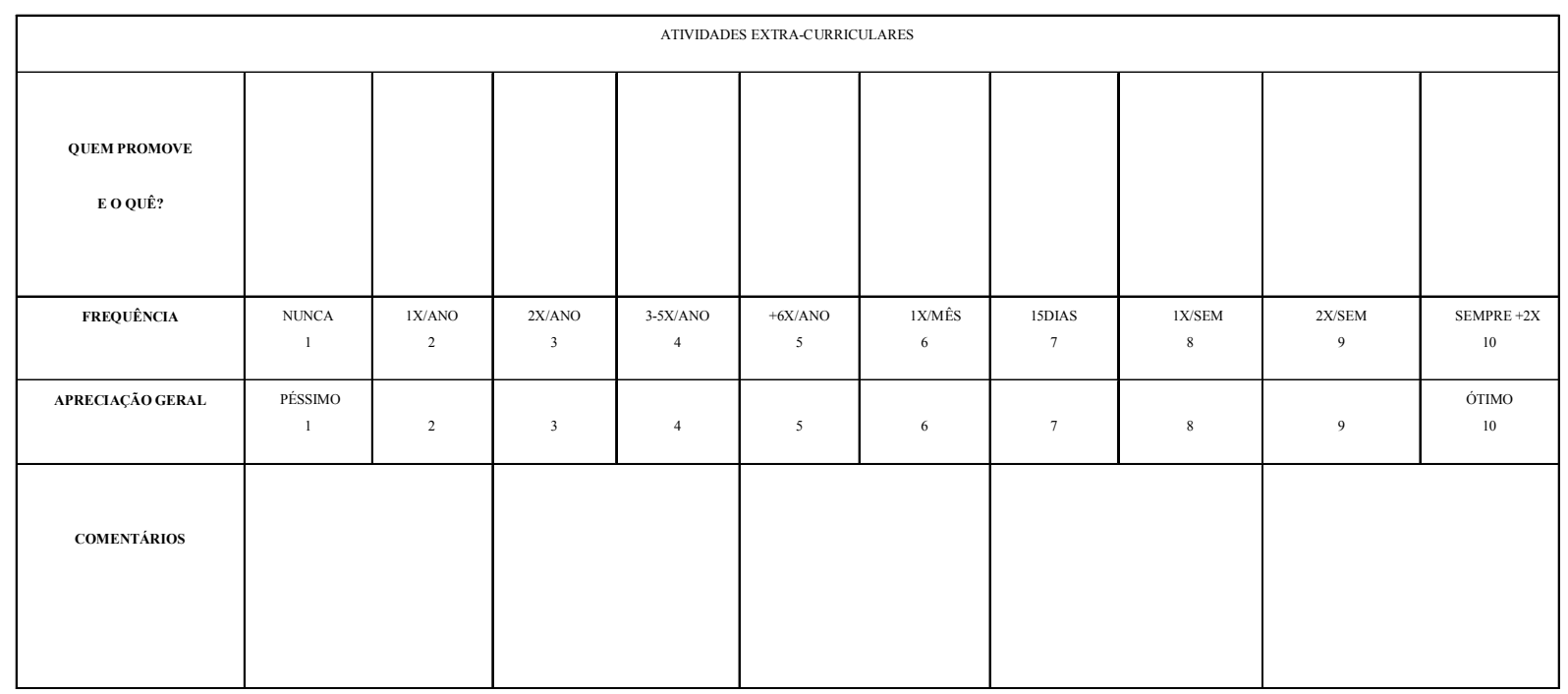

1.4 Qual é a sua religião?

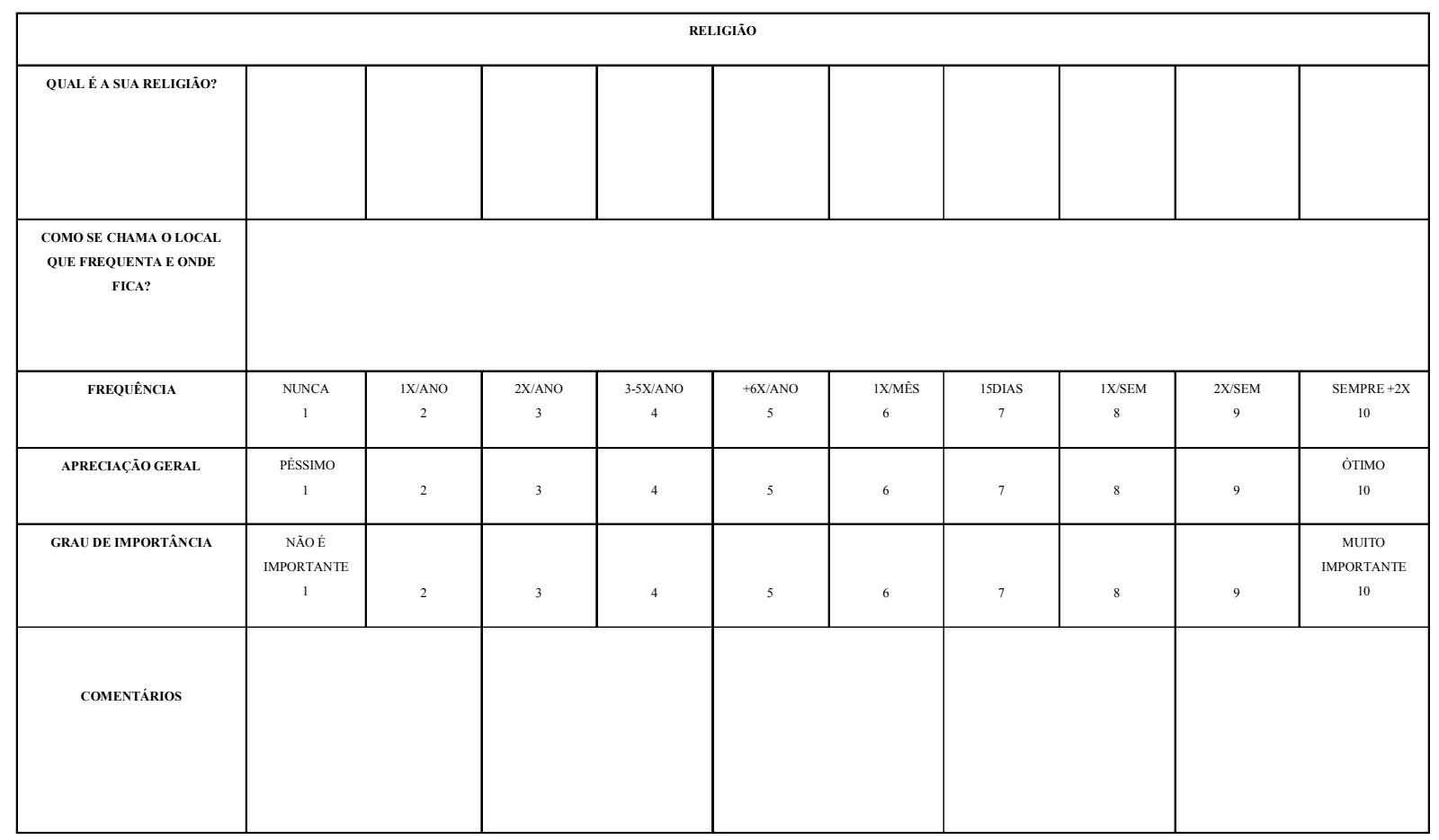


1.5. Freqüência à biblioteca e acessibilidade

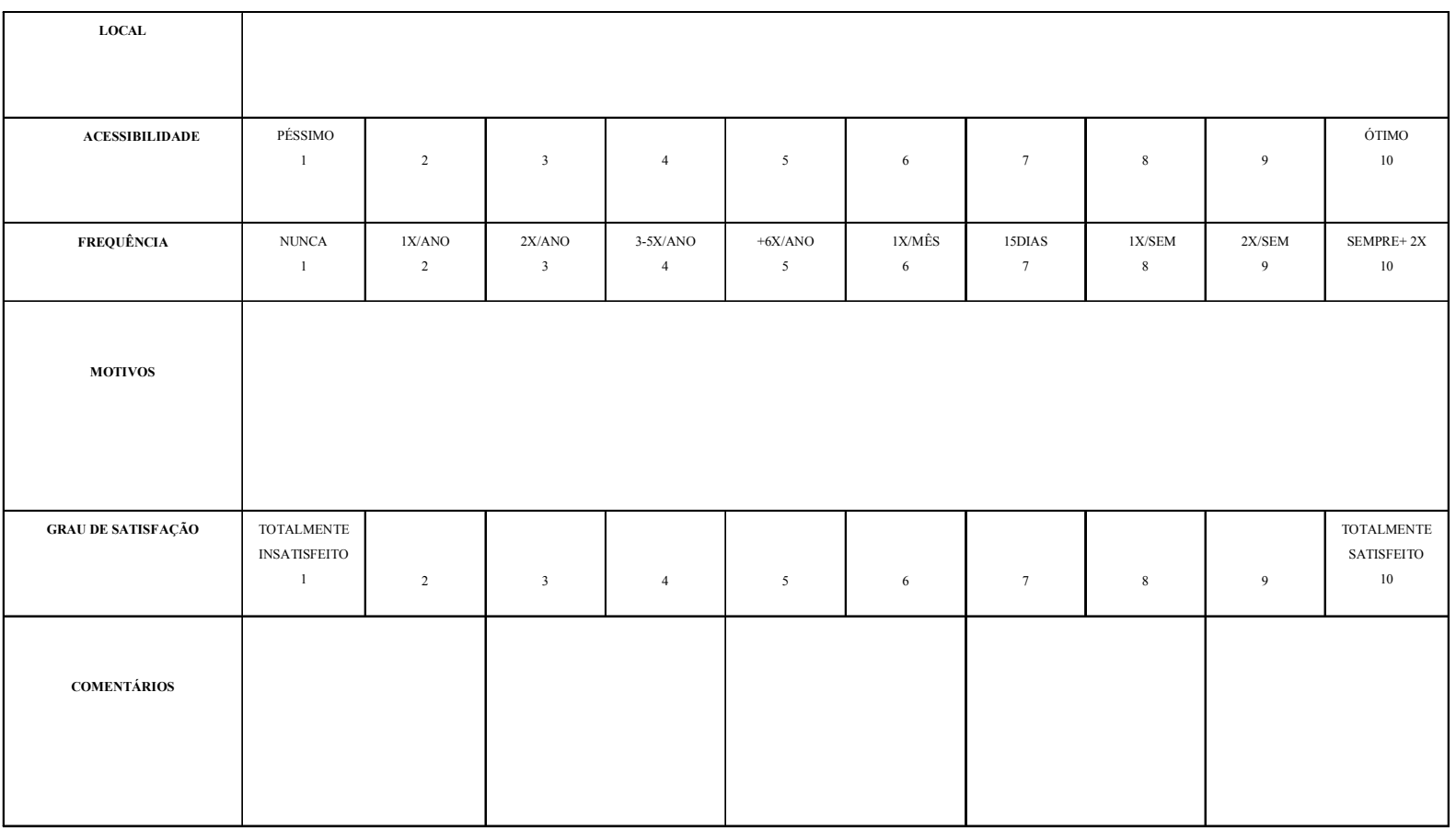

1.6. Qual é o grau de importância da Educação para o seu Desenvolvimento?

\begin{tabular}{|c|c|c|c|c|c|c|c|c|c|c|}
\hline \multicolumn{11}{|c|}{ EDUCAÇÃo } \\
\hline GRAU DE IMPORTÂNCIA & $\begin{array}{c}\text { NÃo Ė } \\
\text { IMPORTANTE } \\
1\end{array}$ & 2 & 3 & 4 & 5 & 6 & 7 & 8 & 9 & $\begin{array}{c}\text { MUITO } \\
\text { IMPORTANTE } \\
10\end{array}$ \\
\hline
\end{tabular}

1. 7. a) Por quê? 


\section{Longevidade}

2.1. Pais

\begin{tabular}{|c|c|c|c|}
\hline Pais & Mãe & Idade & Motivo \\
\hline \multirow{3}{*}{ Vivos } & Pai & & \\
\cline { 2 - 4 } & Mãe & & \\
\hline \multirow{2}{*}{ Mortos } & Pai & & \\
\cline { 2 - 4 } & Pain & & \\
\hline
\end{tabular}

2.2. Freqüência ao médico(a) e motivos

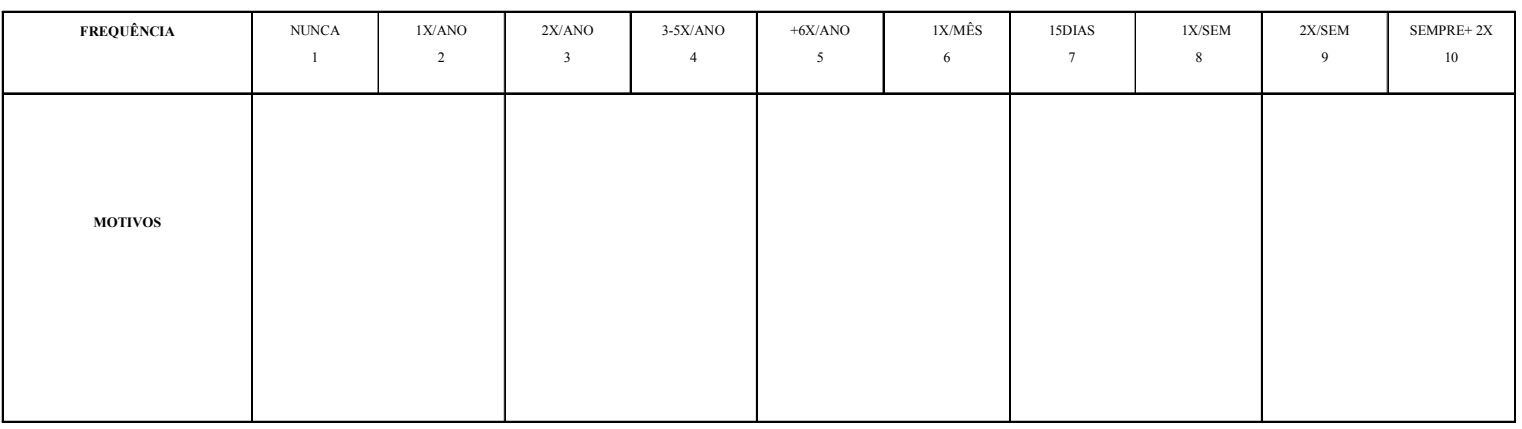

2.3. Localização e acessibilidade ao médico(a)

\begin{tabular}{|c|c|c|c|c|c|c|c|c|c|c|}
\hline LOCAL & & & & & & & & & & \\
\hline ACESSIBLIDADE & $\begin{array}{c}\text { PÉSSIMO } \\
1\end{array}$ & 2 & 3 & 4 & 5 & 6 & 7 & 8 & 9 & $\begin{array}{c}\text { оттімо } \\
10\end{array}$ \\
\hline GRAU DE SATISFAÇ̃̃o & $\begin{array}{c}\text { TOTALMENTE } \\
\text { INSATISFETO } \\
1\end{array}$ & 2 & 3 & 4 & 5 & 6 & 7 & 8 & 9 & $\begin{array}{l}\text { TOTALMENTE } \\
\text { SATISFEIT } \\
10\end{array}$ \\
\hline COMENTÁRIOS & & & & & & & & & & \\
\hline
\end{tabular}


2.4. Condições de saneamento

\begin{tabular}{|c|c|c|c|c|c|c|c|c|c|c|}
\hline CONDIÇÕES DE SANEAMENTO & $\begin{array}{c}\text { PÉsSIMO } \\
1\end{array}$ & 2 & 3 & ${ }^{4}$ & 5 & 6 & 7 & 8 & 9 & $\begin{array}{c}\text { оттімо } \\
10\end{array}$ \\
\hline AGUA & $\begin{array}{c}\text { PÉSIIMO } \\
1\end{array}$ & 2 & 3 & 4 & t & 6 & 7 & 8 & 9 & $\begin{array}{c}\text { Óтімо } \\
10\end{array}$ \\
\hline ESGOTO & $\begin{array}{c}\text { PÉsIIMO } \\
1\end{array}$ & 2 & 3 & 4 & 5 & 6 & 7 & 8 & 9 & $\begin{array}{c}\text { о́тімо } \\
10\end{array}$ \\
\hline LIxo & $\begin{array}{c}\text { PÉSIIMO } \\
1\end{array}$ & 2 & 3 & ${ }^{4}$ & 5 & 6 & 7 & 8 & 9 & $\begin{array}{c}\text { о́тімо } \\
10\end{array}$ \\
\hline MAT. RECICLÁVEL & $\begin{array}{c}\text { PÉsSIMO } \\
1\end{array}$ & 2 & 3 & ${ }^{4}$ & 5 & 6 & 7 & 8 & 9 & $\begin{array}{l}\text { ӧтімо } \\
10\end{array}$ \\
\hline AGROTÓXICOS & $\begin{array}{c}\text { PÉSIIMO } \\
1\end{array}$ & 2 & 3 & 4 & 5 & 6 & 7 & 8 & 9 & $\begin{array}{c}\text { Óтімо } \\
10\end{array}$ \\
\hline
\end{tabular}

2.5. Alimentação

\begin{tabular}{|c|c|c|c|c|c|c|c|c|c|c|}
\hline FREQUÊNCIA & $\begin{array}{c}\text { NUNCA } \\
1\end{array}$ & $\begin{array}{c}\text { IX/ANO } \\
2\end{array}$ & $\begin{array}{c}\text { 2X/ANO } \\
3\end{array}$ & $\begin{array}{c}\text { 3.5X/ANO } \\
4\end{array}$ & $\begin{array}{c}+6 \mathrm{XXANO} \\
5\end{array}$ & $\begin{array}{l}\text { IX/MÊs } \\
6\end{array}$ & $\begin{array}{c}\text { 15DIAS } \\
7\end{array}$ & $\begin{array}{l}\text { 1X/SEM } \\
8\end{array}$ & $\begin{array}{c}\text { 2X/SEM } \\
9\end{array}$ & $\begin{array}{c}\text { SEMPRE }+2 X \\
10\end{array}$ \\
\hline \multicolumn{11}{|l|}{ CESTA BásICa } \\
\hline \multicolumn{11}{|c|}{ ASSISTÊNCIA SOCIAL } \\
\hline \multicolumn{11}{|l|}{ COMPRA } \\
\hline \multicolumn{11}{|l|}{ PRODUZ } \\
\hline \multicolumn{11}{|c|}{ COLETA EM ATERRO } \\
\hline \multicolumn{11}{|l|}{ OUTROS } \\
\hline COMENTÁRIOS & & & & & & & & & & \\
\hline & & & & & & & & & & \\
\hline
\end{tabular}


2.6. Qual é o grau de importância da Saúde para o seu Desenvolvimento?

\begin{tabular}{|c|c|c|c|c|c|c|c|c|c|c|}
\hline \multicolumn{11}{|c|}{ SAÚde } \\
\hline GRAU DE IMPORTÂNCIA & $\begin{array}{c}\text { NÃó丶 É } \\
\text { IMPORTANTE } \\
1\end{array}$ & 2 & 3 & 4 & 5 & 6 & 7 & 8 & 9 & $\begin{array}{c}\text { MUITO } \\
\text { IMPORTANTE } \\
10\end{array}$ \\
\hline
\end{tabular}

2.6. a) Por quê?

2.7. Existem trabalhos para o cuidado com o meio ambiente / quem promove?

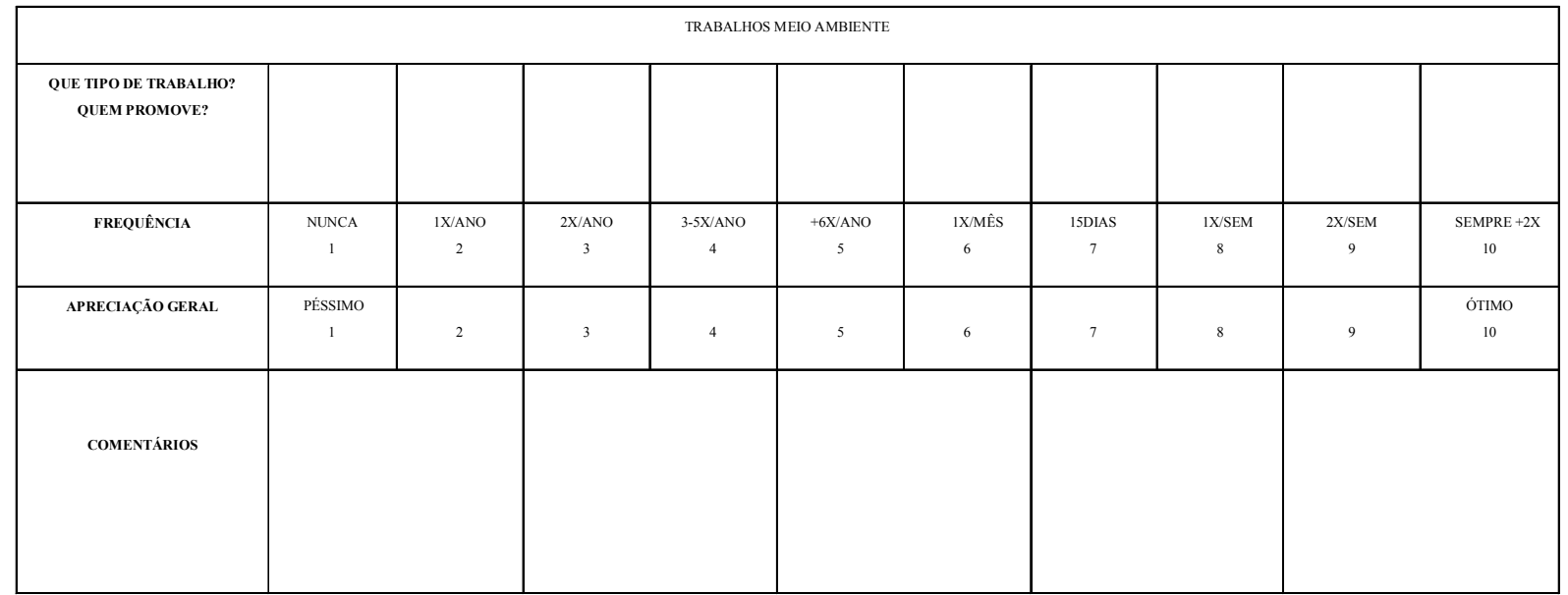


2.8. Lazer

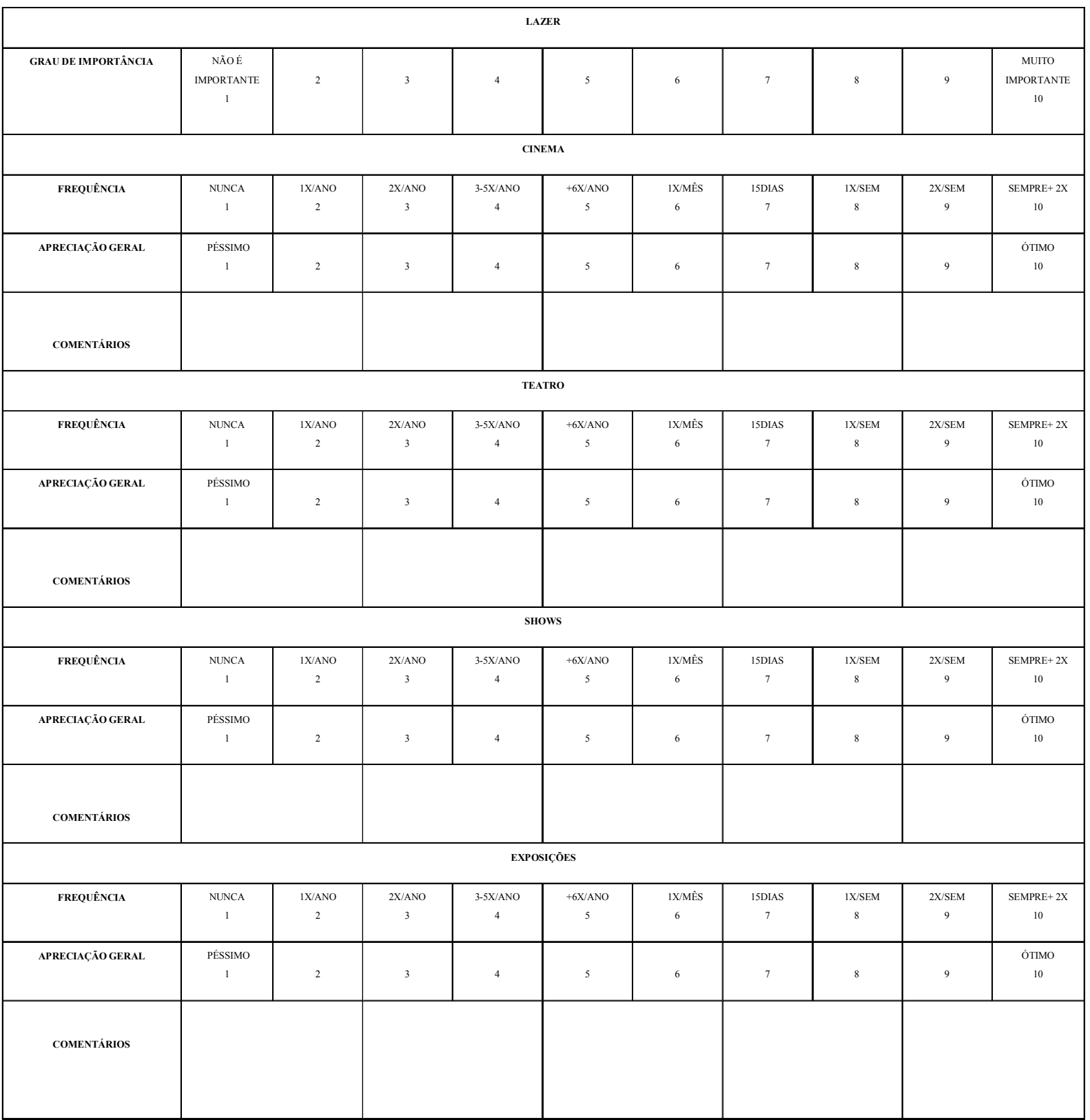


2.9. Grau de importância / Atividade?

\begin{tabular}{|c|c|c|c|c|c|c|c|c|c|c|}
\hline \multicolumn{11}{|c|}{ GRAU DE IMPORTÂNGA / ATIVIDADE } \\
\hline ATIVIDADES & $\begin{array}{c}\text { NÃó̉ } \\
\text { IMPORTANTE } \\
1\end{array}$ & 2 & 3 & 4 & 5 & 6 & 7 & 8 & 9 & $\begin{array}{c}\text { MUITO } \\
\text { IMPORTANTE } \\
10\end{array}$ \\
\hline CINEMA & & & & & & & & & & \\
\hline TEATRO & & & & & & & & & & \\
\hline sHows & & & & & & & & & & \\
\hline EXPOSIÇ̄ES & & & & & & & & & & \\
\hline OUtRos & & & & & & & & & & \\
\hline COMENTARIOS & & & & & & & & & & \\
\hline
\end{tabular}

2.10. O que tem de bom para fazer onde mora?

\begin{tabular}{|c|c|c|c|c|c|c|c|c|c|c|c|c|c|c|c|c|c|c|c|c|c|c|c|c|c|c|c|c|c|c|}
\hline \multirow[b]{2}{*}{$\begin{array}{l}\text { FATER O } \\
\text { QUÊ?? }\end{array}$} & \multicolumn{10}{|c|}{ FREQUÊNCIA } & \multicolumn{10}{|c|}{ APRECIAÇ̃̃o GERAL } & \multicolumn{10}{|c|}{ GRAU DE IMPORTÂNCIA } \\
\hline & $\begin{array}{c}\text { Nc } \\
1\end{array}$ & 2 & 3 & 4 & s & 6 & 7 & 8 & , & $\begin{array}{l}\text { SE } \\
10\end{array}$ & $\begin{array}{c}\text { Pés } \\
1\end{array}$ & 2 & 3 & 4 & & 6 & 7 & & & 2 & $\begin{array}{l}\text { SÉm } \\
1\end{array}$ & 2 & $3^{3}$ & 4 & 5 & 6 & ? & 8 & , & $\begin{array}{c}\text { мто гм } \\
10\end{array}$ \\
\hline & & & & & & & & & & & & & & & & & & & & & & & & & & & & & & \\
\hline & & & & & & & & & & & & & & & & & & & & & & & & & & & & & & \\
\hline & & & & & & & & & & & & & & & & & & & & & & & & & & & & & & \\
\hline & & & & & & & & & & & & & & & & & & & & & & & & & & & & & & \\
\hline & & & & & & & & & & & & & & & & & & & & & & & & & & & & & & \\
\hline & & & & & & & & & & & & & & & & & & & & & & & & & & & & & & \\
\hline & & & & & & & & & & & & & & & & & & & & & & & & & & & & & & \\
\hline & & & & & & & & & & & & & & & & & & & & & & & & & & & & & & \\
\hline
\end{tabular}

2.10. a) O que gostaria que tivesse para fazer onde mora? 
2.11. O que tem de belo para ver onde mora?

\begin{tabular}{|c|c|c|c|c|c|c|c|c|c|c|c|c|c|c|c|c|c|c|c|c|c|c|c|c|c|c|c|c|c|}
\hline \multirow[b]{2}{*}{$\begin{array}{l}\text { VER O } \\
\text { QUUE? }\end{array}$} & \multicolumn{10}{|c|}{ FREQUENNCA } & \multicolumn{9}{|c|}{ APRECAAÇ̃̃o GERAL } & \multicolumn{10}{|c|}{ GRAU DE IMPORTÂNCIA } \\
\hline & $\begin{array}{c}\mathrm{Ne} \\
\mathrm{N}\end{array}$ & 2 & 3 & 4 & $s$ & 6 & 7 & 8 & , & $\begin{array}{l}\text { Semm } \\
\text { 10 }\end{array}$ & $\begin{array}{c}\mathrm{Pé} \\
1\end{array}$ & 2 & \begin{tabular}{l|l}
34 & 4
\end{tabular} & s & . & 7 & 8 & , & $\begin{array}{c}\text { किष } \\
2\end{array}$ & $\begin{array}{c}\mathrm{NEMM} \\
1\end{array}$ & 2 & 3 & 4 & 5 & 6 & ? & 8 & , & $\begin{array}{c}\text { мто ом } \\
10\end{array}$ \\
\hline & & & & & & & & & & & & & & & & & & & & & & & & & & & & & \\
\hline & & & & & & & & & & & & & & & & & & & & & & & & & & & & & \\
\hline & & & & & & & & & & & & & & & & & & & & & & & & & & & & & \\
\hline & & & & & & & & & & & & & & & & & & & & & & & & & & & & & \\
\hline & & & & & & & & & & & & & & & & & & & & & & & & & & & & & \\
\hline & & & & & & & & & & & & & & & & & & & & & & & & & & & & & \\
\hline & & & & & & & & & & & & & & & & & & & & & & & & & & & & & \\
\hline & & & & & & & & & & & & & & & & & & & & & & & & & & & & & \\
\hline
\end{tabular}

2.11. a ) O que gostaria de ver onde mora?

\section{Renda}

3.1. Rendimento por pessoa

\begin{tabular}{|c|c|c|c|c|}
\hline \multicolumn{5}{|c|}{ RENDIMENTO/PESSOA } \\
\hline & SALÁRIO(RS)/AUXXILIOS & FREQUENNCIA & OCUPAÇ̃̃o & ORIGEM \\
\hline 1 & & & & \\
\hline 2 & & & & \\
\hline 3 & & & & \\
\hline 4 & & & & \\
\hline 5 & & & & \\
\hline 6 & & & & \\
\hline & & & & \\
\hline 7 & & & & \\
\hline & & & & \\
\hline
\end{tabular}


3.2. Gastos/ Receita

\begin{tabular}{|c|c|c|c|c|c|c|c|c|}
\hline \multicolumn{9}{|c|}{ GASTOS/MÊS (RS) } \\
\hline ALUGUEL & ÁGUA & LuZ & TELEFONE & TRANSPORTE & ALIMETAÇão & PRODUÇÃO & $\begin{array}{c}\text { AJUDA } \\
\text { EXTERNAMENTE }\end{array}$ & OUtros \\
\hline & & & & & & & & \\
\hline & & & & & & & & \\
\hline & & & & & & & & \\
\hline & & & & & & & & \\
\hline
\end{tabular}

3.3. Quem decide pelo uso da renda familiar?

( ) Todos na família, exceto as crianças

( ) Os pais e os filhos que contribuem para a formação da renda familiar
( ) Os pais ( ) somente o pai
( ) somente a mãe
( ) somente o filho(a) mais velho(a)

( ) Outro. Quem? 


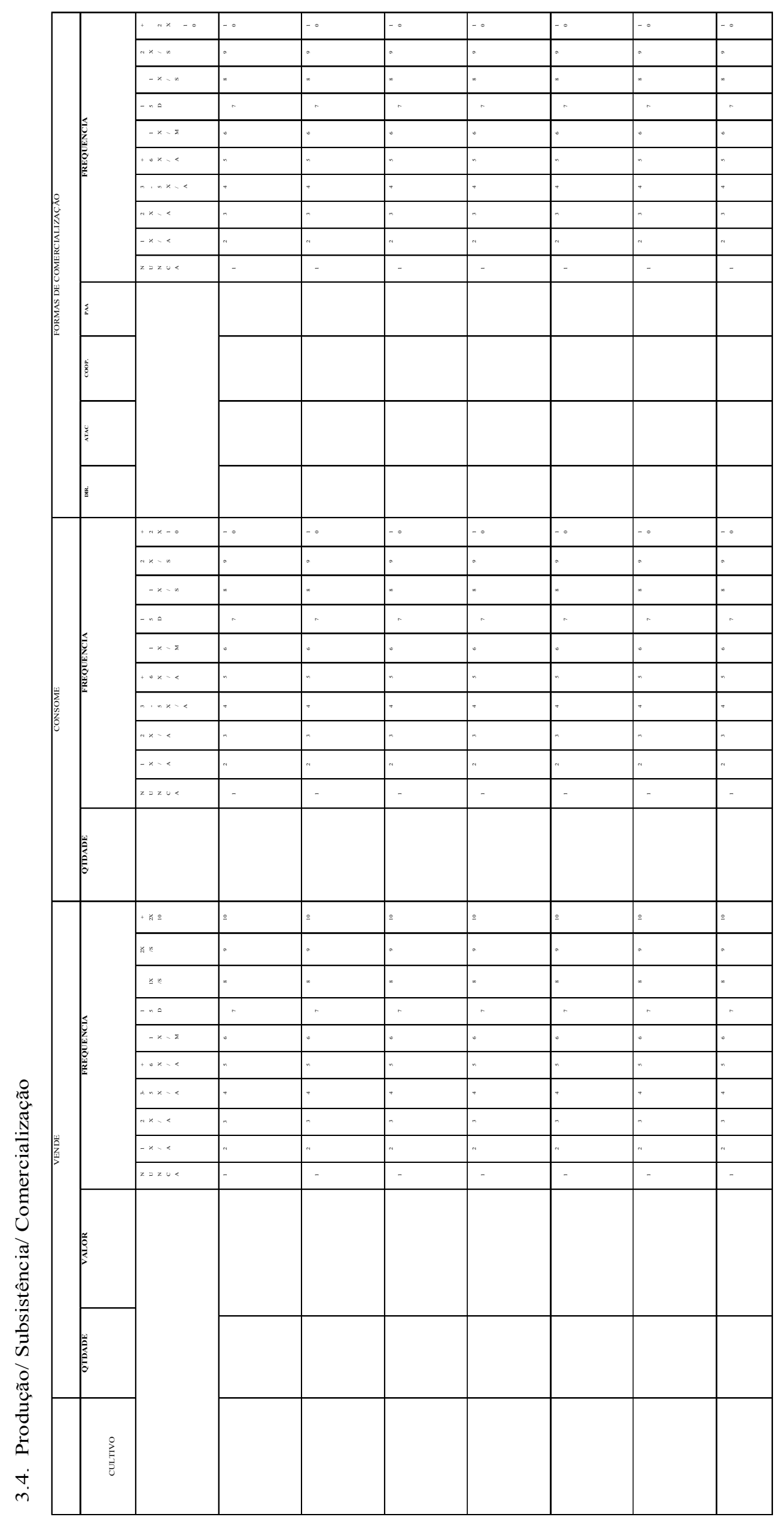


3.5. Você acha importante consumir o que você produz?

\begin{tabular}{|c|c|c|c|c|c|c|c|c|c|c|}
\hline \multicolumn{11}{|c|}{ SUSTENTABLLIDADE } \\
\hline GRAU DE IMPORTÂNCIA & $\begin{array}{c}\text { NÃo Ė } \\
\text { IMPORTANTE } \\
\end{array}$ & 2 & 3 & 4 & 5 & 6 & 7 & 8 & 9 & $\begin{array}{c}\text { MUITO } \\
\text { IMPORTANTE } \\
10\end{array}$ \\
\hline
\end{tabular}

3.5. a) Por quê?

3.6. Você está satisfeito com a forma com que você comercializa seus produtos?

\begin{tabular}{|c|c|c|c|c|c|c|c|c|c|c|}
\hline \multicolumn{11}{|c|}{ COMERCIALIZAÇÃo } \\
\hline GRAu dE SATISFAÇÃo & $\begin{array}{c}\text { INSATISFEITO } \\
1\end{array}$ & 2 & 3 & 4 & 5 & 6 & 7 & 8 & 9 & $\begin{array}{l}\text { SATISFEITO } \\
10\end{array}$ \\
\hline
\end{tabular}

3.6.. a) Por quê?

\subsection{Articulação institucional}

\begin{tabular}{|c|c|c|c|c|c|c|c|c|c|c|}
\hline $\begin{array}{l}\text { FAZ PARTE DE ALGUM TIPO } \\
\text { DE ORGANIZAČ̃O SOCIAL? }\end{array}$ & \multicolumn{2}{|c|}{ MOVIMENTO SOCIAL } & & & \multicolumn{2}{|c|}{ ASSOCIAÇÃo } & \multicolumn{2}{|c|}{ ONG } & \multicolumn{2}{|c|}{ OUTROS } \\
\hline \multicolumn{11}{|l|}{$\begin{array}{l}\text { COMO SE CHAMA E ONDE } \\
\text { ACONTECEM AS REUNIÓES? }\end{array}$} \\
\hline FREQUÊNCIA & $\begin{array}{c}\text { NUNCA } \\
1\end{array}$ & $\begin{array}{l}\text { IX/ANO } \\
2\end{array}$ & $\begin{array}{c}2 \mathrm{2XIANO} \\
3\end{array}$ & $\begin{array}{c}3.5 \mathrm{X} / \mathrm{ANO} \\
4\end{array}$ & $\begin{array}{c}+6 \text { XXANO } \\
5\end{array}$ & $\begin{array}{l}\text { 1XMÊS } \\
6\end{array}$ & $\begin{array}{c}\text { 15DIAS } \\
7\end{array}$ & $\begin{array}{l}\text { 1X/SEM } \\
8\end{array}$ & $\begin{array}{c}\text { 2XXSEM } \\
9\end{array}$ & $\begin{array}{c}\text { SEMPRE }+2 \mathrm{X} \\
10\end{array}$ \\
\hline APRECIAÇ̃̃O GERAL & $\begin{array}{l}\text { PÉsSIMO } \\
1\end{array}$ & 2 & 3 & 4 & 5 & 6 & 7 & 8 & 9 & $\begin{array}{l}\text { о́тімо } \\
10\end{array}$ \\
\hline GRAU DE IMPORTÂNCIA & $\begin{array}{c}\text { NÃOÉ } \\
\text { IMPORTANTE } \\
1\end{array}$ & 2 & 3 & 4 & 5 & 6 & 7 & 8 & 9 & $\begin{array}{c}\text { MUITO } \\
\text { IMPORTANTE } \\
10\end{array}$ \\
\hline COMENTÁRIOS & & & & & & & & & & \\
\hline
\end{tabular}


3.8. Qual a área do domicílio/lote?

$\mathrm{m}^{2} /$

ha.

$\mathrm{N}^{\mathrm{o}}$ cômodos?

$\mathrm{N}^{\mathrm{o}}$ quartos?

É proprietário (a) ? ( )Sim ( )Não.

Ocupa este domicílio sob que condição ( )Arrendatário ( ) Parceiro ( ) Posseiro ( ) Cessionário ( ) Inquilino

3.9. Qual é o grau de importância da Renda e do Trabalho para o seu Desenvolvimento?

\begin{tabular}{|c|c|c|c|c|c|c|c|c|c|c|}
\hline \multicolumn{11}{|c|}{ RENDA } \\
\hline GRAU DE IMPORTÂNCIA & $\begin{array}{c}\text { Não Ė } \\
\text { IMPORTANTE } \\
1\end{array}$ & 2 & 3 & 4 & 5 & 6 & 7 & 8 & 9 & $\begin{array}{c}\text { MUITO } \\
\text { IMPORTANTE } \\
10\end{array}$ \\
\hline
\end{tabular}

3. 9. a) Por quê? 
4. Campo /Cidade

4.1.Como você se define, como uma pessoa do campo ou da cidade? Por quê?

4.2. Qual o seu sonho, o que é preciso para realizá-lo?

4.3. Para você o que é o Desenvolvimento Humano? 